Doktori (Ph.D.) értekezés

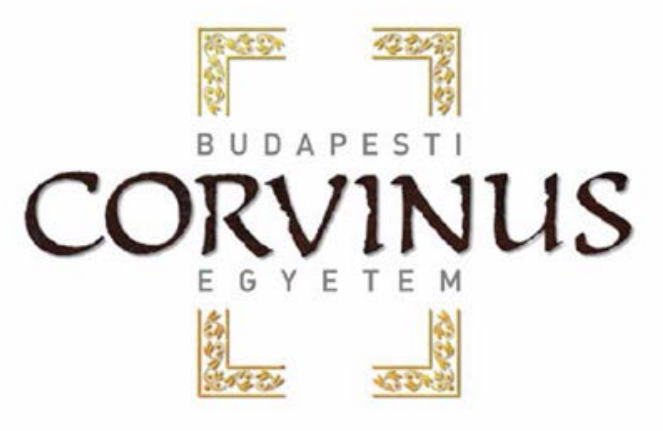

\title{
A JÓSIKA-ORGONA (SYRINGA JOSIKAEA JACQ. FIL. EX RCHB.) AKTUÁLIS ÉS TÖRTÉNETI BIOGEOGRÁFIÁJA
}

\author{
Lendvay Bertalan
}

Kertészettudományi Doktori Iskola

Budapesti Corvinus Egyetem

Genetika és Növénynemesítés Tanszék

Budapest 
A doktori iskola

megnevezése:

Kertészettudományi Doktori Iskola

tudományága:

Növénytermesztési és kertészeti tudományok

vezetője:

Dr. Tóth Magdolna

egyetemi tanár, DSc

Budapesti Corvinus Egyetem, Kertészettudományi Kar, Gyümölcstermő Növények Tanszék

Témavezetők:

Dr. Höhn Mária

egyetemi docens, CSc

Budapesti Corvinus Egyetem, Kertészettudományi Kar, Növénytani Tanszék és Soroksári Botanikus Kert

Dr. Pedryc Andrzej

egyetemi tanár, DSc

Budapesti Corvinus Egyetem, Kertészettudományi Kar, Genetika és Növénynemesítés Tanszék

A jelölt a Budapesti Corvinus Egyetem Doktori Szabályzatában előírt valamennyi feltételnek eleget tett, az értekezés mühelyvitájában elhangzott észrevételeket és javaslatokat az értekezés átdolgozásakor figyelembe vette, azért az értekezés védési eljárásra bocsátható.

Dr. Tóth Magdolna

Dr. Höhn Mária

Dr. Pedryc Andrzej

A doktori iskola vezetőjének jóváhagyása

A témavezetők jóváhagyása 
A Budapesti Corvinus Egyetem Élettudományi Területi Doktori Tanácsának 2014.03.18-i határozatában a nyilvános vita lefolytatására az alábbi bíráló Bizottságot jelölte ki:

\title{
BÍRÁLÓ BIZOTTSÁG:
}

\author{
Elnöke \\ Palkovics László, DSc
}

Tagjai

Bisztray György, $\mathrm{PhD}$

Deák Tamás, $\mathrm{PhD}$

Csiky János, $\mathrm{PhD}$

Pócs Tamás, MHAS

Opponensek

Halász Júlia, $\mathrm{PhD}$

Kovács J. Attila, CSc

Titkár

Deák Tamás, $\mathrm{PhD}$ 


\section{Tartalomjegyzék}

Rövidítések jegyzéke .........................................................................................6

Táblázatok jegyzéke.............................................................................................. 7

Ábrák jegyzéke ....................................................................................................... 7

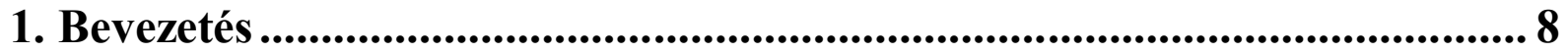

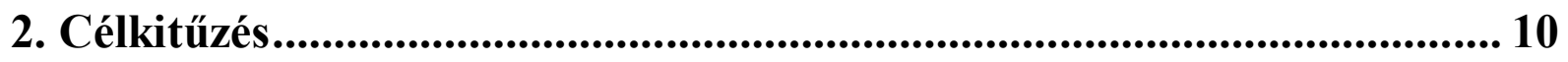

3. Irodalmi áttekintés ........................................................................... 11

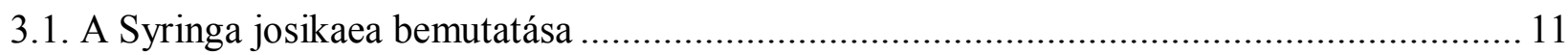

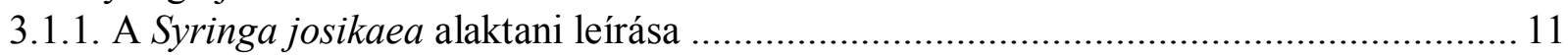

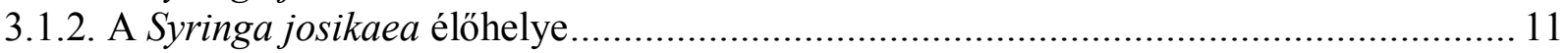

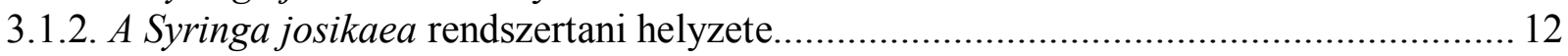

3.1.3. A Syringa josikaea szükebben vett rokonsága ............................................................ 14

3.2. Fosszilis Syringa maradványok Európából és elméletek a Syringa josikaea származásával

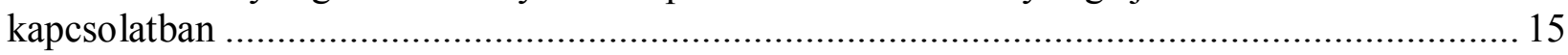

3.3. Eurázsia flórájának alakulása a Kainozoikumban, eurázsiai diszjunkciók és Tercier

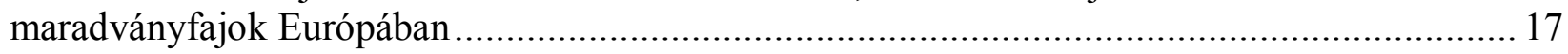

3.4. Populációgenetikai vizsgálati módszerek és vizsgálatok a Syringa josikaea rokonainál....... 20

3.4.1. Nukleotid sorrenden alapuló DNS markerek ............................................................. 21

3.4.2. Hosszpolimorfizmuson alapuló DNS markerek........................................................22

3.5. A Syringa josikaea Erdélyi-szigethegységi elterjedésének szakirodalma ...............................2 23

3.5.1. A Syringa josikaea felfedezése az Erdélyi-szigethegységben ....................................... 24

3.5.2. Az első elő fodulási adatok 1830-tól 1880-ig ..............................................................2

3.5.3. Az elterjedési terület feltárása az 1880-as években.................................................... 26

3.5.4. 1890-1908: áttekintő tanulmányok az addig megismert elterjedésről..............................22

3.5.5. Az elterjedés további pontosítása Blattny Tibor nyomán 1909-töl 1913-ig .................... 29

3.5.6. Fekete Lajos és Blattny Tibor - a korábbról ismert elterjedési adatok és az újabb kutatási eredmények szintézise, 1913 ............................................................................................... 31

3.5.7. Az I. világháborútól napjainkig keletkezett szakirodalom............................................ 33

3.5.8. A munkám kezdetéig elfogadott Syringa josikaea elterjedési adatok az Erdélyi-

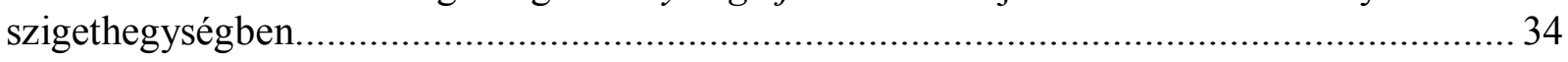

3.6. A Syringa josikaea elterjedési adatai az Ukrajnai-Kárpátokban.......................................... 37

4. Anyag és módszer ...................................................................................40

4.1. A Syringa josikaea Erdélyi-szigethegységi elterjedésének felmérése …………................... 40

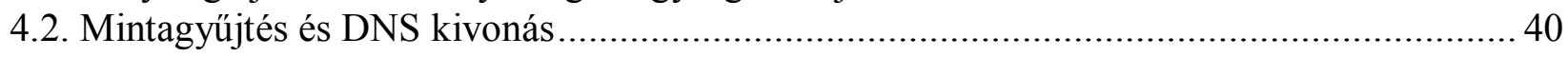

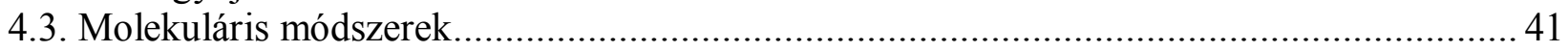

4.3.1. Fajon belül variábilis DNS szakaszok keresése …………………………………..... 41

4.3.2.Nukleáris mikroszatellit markerek tesztelése és fejlesztése.............................................. 46

4.3.2.1. Olea és Ligustrum mikroszatellit markerek használhatósága a Syringa josikaea

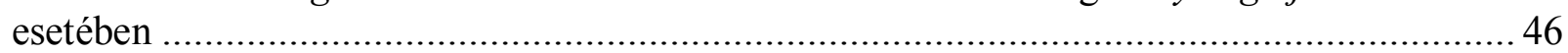

4.3.2.2. De novo mikroszatellit marker fejlesztés ................................................................ 47

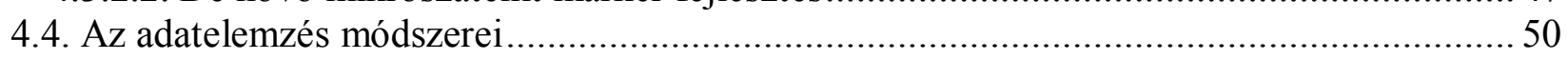

4.4.1. A Syringa josikaea divergencia idejének kiszámítása molekuláris óra analízissel.........50

4.4.2. Szekvencia variabilitás a Syringa josikaea populációk közt ...........................................52

4.4.3. Mikroszatellit markerek tesztelése és fejlesztése .......................................................53

4.4.4. A mikroszatellit adatok kiértékelése és adatelemzése ...................................................53

4.4.4.1. Az egy klónhoz tartozó minták összevonása............................................................. 53 


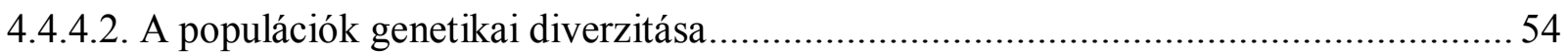

4.4.4.3. A populációk genetikai különbségei földrajzi helyzetük figyelembevételével............55

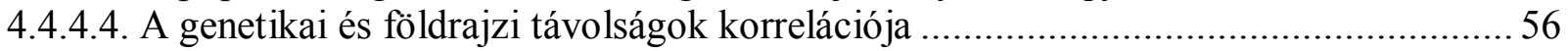

5. Eredmények..................................................................................... 57

5.1. A Syringa josikaea szakirodalomban jelzett állományainak felkutatása az Erdélyi-

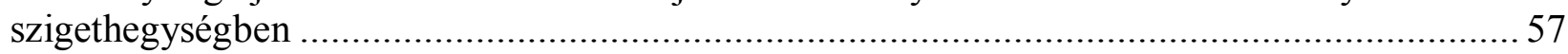

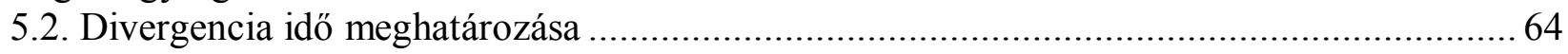

5.3. DNS szekvenciák változékonyságának tesztelése a Syringa josikaea populációi közt.......... 65

5.4. A variábilis DNS szakaszok fajon belüli variabilitása és eloszlása ....................................66 66

5.5. Mikroszatellit markerek tesztelése és tervezése........................................................69

5.5.1. Olea és Ligustrum mikroszatellit markerek használhatósága a Syringa josikaea esetében

5.5.2. De novo mikroszatellit markertervezés ............................................................. 70

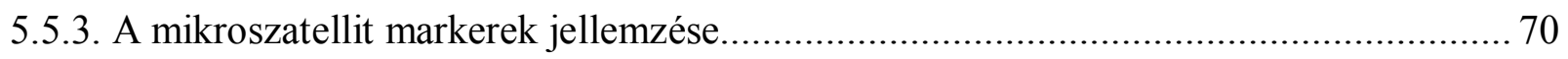

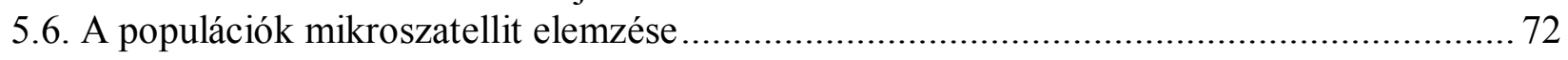

6. Következtetések ......................................................................................... 78

6.1. A Syringa josikaea aktuális elterjedése az Erdélyi-szigethegységben .............................. 78

6.2. A Syringa josikaea populációk veszélyeztető tényezői az Erdélyi-szigethegységben........... 78

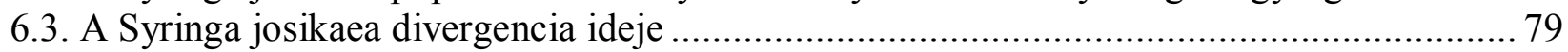

6.4. Kismértékü szekvencia variabilitás a Syringa josikaea populációi közt ........................... 81

6.5. A riboszomális lókuszok típusai és leszármazása ..................................................... 81

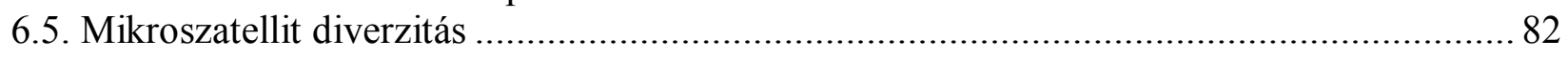

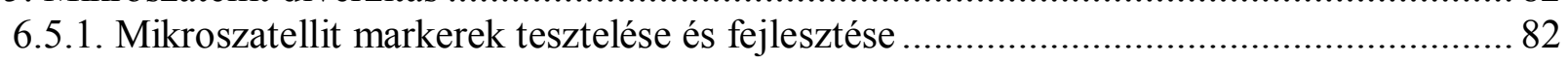

6.5.2. A Syringa josikaea mikroszatellit diverzitása ........................................................ 83

6.6. A Syringa josikaea két diszjunkt areajának lehetséges flóratörténeti viszonya...................... 85

7. Új tudományos eredmények ....................................................................... 88

8. Összefoglalás............................................................................................. 89

9. Summary ........................................................................................................ 91

10. Köszönetnyilvánítás ............................................................... 93

11. Irodalomjegyzék................................................................................... 94

12. Függelék ................................................................................ 114 


\section{Rövidítések jegyzéke}

$\begin{array}{ll}\begin{array}{l}\text { bp } \\ \text { BSA } \\ \text { cpRFLP }\end{array} & \begin{array}{l}\text { Bázispár } \\ \text { Bovine Serum Albumin } \\ \text { Chloroplast Restriction Fragment Length Polymorphism } \\ \text { (Kloroplasztisz restrikciós framenthossz polimorfizmus) } \\ \text { ETS }\end{array} \\ \begin{array}{l}\text { Ribosomal External Transcribed Spacer (Riboszomális külső } \\ \text { átódó szakasz) }\end{array} \\ \text { FIASCO } & \text { Fast Isolation by AFLP of Sequences COntaining repeats } \\ \text { IGS } & \text { Ribosomal Intergenic Spacer (Riboszomális gének közti elválasztó } \\ \text { ISSR } & \text { Inter Simple Sequence Repeat } \\ \text { ITS } & \text { Internal Transcribed Spacer (Riboszomális belső átíródó szakasz) } \\ \text { LCNG } & \text { Low-copy Nuclear Gene (Alacsony kópiaszámú nukláris gén) } \\ \text { MCMC } & \text { Markov-chain Monte Carlo (Markov-lánc Monte Carlo) } \\ \text { MLG } & \text { Multilocus Genotype (Multilókusz genotípus) } \\ \text { PCR } & \text { Polymerase Chain Reaction (Polimeráz-láncreakció) } \\ \text { RAPD } & \text { Random Amplified Polymorphic DNA } \\ \text { U } & \text { Unit (Egység) }\end{array}$




\section{Táblázatok jegyzéke}

\begin{tabular}{|c|c|c|}
\hline Táblázat sorszáma & Oldalszám & Tartalom \\
\hline 1. & 13. & A Syringa fajok listája \\
\hline 2. & 19. & Néhány Tercier reliktum fásszárú faj \\
\hline 3. & 20. & Eurázsiai diszjunkciók kialakulási ideje \\
\hline 4. & $38-39$. & $\begin{array}{l}\text { A Syringa josikaea populációk elterjedése az Ukrajnai- } \\
\text { Kárpátokban }\end{array}$ \\
\hline 5. & $43-45$. & $\begin{array}{l}\text { A Syringa josikaea populációk variabilitására vizsgált DNS } \\
\text { szakaszok }\end{array}$ \\
\hline 6. & 67. & A Syringa josikaea ribotípusai \\
\hline 7. & 69. & $\begin{array}{l}\text { A Syringa josikaea genomján tesztelt Olea és Ligustrum } \\
\text { mikroszatellit lókuszok }\end{array}$ \\
\hline 8. & 71. & $\begin{array}{l}\text { A Syringa josikaea genomján sikeresen amplifikált } \\
\text { mikroszatellitek primerjei }\end{array}$ \\
\hline 9. & 72. & A mikroszatellit markerek diverzitás jellemzői \\
\hline 10 . & 73. & $\begin{array}{l}\text { A genetikailag analizált Syringa josikaea minták száma } \\
\text { populációnként }\end{array}$ \\
\hline
\end{tabular}

\section{Ábrák jegyzéke}

\begin{tabular}{ccl}
\hline Ábra sorszáma & Oldalszám & Tartalom \\
\hline 1. & 11. & A Syringa josikaea virágzó példánya \\
2. & 13. & A Syringa genus elterjedése \\
3. & 24. & A legkorábbi Syringa josikaea herbáriumi példány etikettje \\
4. & 27. & Herbáriumi etikett Syringa vincetoxicifolia névvel \\
5. & 30. & Archiv felvétel a Syringa josikaea egy Jád-völgyi példányáról \\
6. & 31. & Syringa josikaea herbáriumi példány etikettje az Obersia-völgyből \\
7. & 37. & A Syringa josikaea ismert erdélyi elterjedése 2009-ben \\
8. & 37. & A Syringa josikaea elterjedése az Ukrajnai-Kárpátokban \\
9. & 48. & A mikroszatellit fejlesztés protokolljának sematikus rajza \\
10. & 57. & A Syringa josikaea fellelt állományai az Erdélyi-szigethegységben \\
11. & $61-63$. & Syringa josikaea példányok fényképei az Erdélyi-szigethegységből \\
12. & 65. & Bayesi filogenetikai törzsfa divergencia időkkel \\
13. & 67. & A Syringa josikaea ribotípusainak minimum-spanning hálózata \\
14. & 68. & A Syringa josikaea ribotípusainak földrajzi eloszlása \\
15. & 72. & A Syr9 mikroszatellit lókusz alléljainak megjelenése \\
16. & 75. & A Syringa josikaea egyedei genetikai csoportokhoz rendelve a \\
& & STRUCTURE analízis eredménye alapján \\
17. & 77. & A Syringa josikaea populációk genetikai jellemzői mikroszatellit \\
& & markerek alapján \\
\hline
\end{tabular}




\section{Bevezetés}

A Jósika-orgona (Syringa josikaea Jacq. fil. ex Rchb.) az Erdélyi-szigethegység és az Ukrajnai-Kárpátok bennszülött cserjefaja. Rokonságának ázsiai elterjedése miatt vetődött föl, hogy egy reliktum fajjal állunk szemben. Ez a kérdés már több, mint száz éve (Pax 1898) foglalkoztatja a szakmai közvéleményt. Annak hatására, hogy fosszíliákat $S$. josikaea őseként azonosítottak, mára e faj a Kárpát-medence harmadkori reliktumainak tankönyvi példája lett. A reliktum növényfajok történeti biogeográfiája eltér az egyes területeket borító növényzet többségéhez képest, emiatt a reliktumok történeti biogeográfiája fontos adatokkal egészítheti ki a flóratörténetröl szerzett ismereteket. A rokonság elterjedésének ismerete és néhány fosszília alapján azonban a fajok származásáról és történeti biogeográfiájáról csak bizonytalansággal lehet hipotéziseket felállítani. Különösen igaz ez régebbi földtörténeti korok reliktumai esetében, ahol az eltelt hosszú idő alatt számos tényező befolyásolhatta a faj fennmaradását és elterjedését. Az utóbbi évtizedekben a molekuláris genetikai technikák fejlődése új lehetőséget adott a fajtörténet feltárásához és évszázados hipotézisek igazolására vagy elvetésére (Avise 2000). Molekuláris genetikai módszerekkel vizsgálhatóvá vált a $S$. josikaea leszármazási ideje, és hogy ez milyen földtörténeti eseményekkel áll kapcsolatban.

A reliktum fajok elterjedése olyan kisméretü refúgium területre korlátozódik, ahol az élőhelyi feltételek adottak a fennmaradáshoz. A szük elterjedésési területtel rendelkező, ökológiai optimumuk határán élö, alacsony rezilienciájú fajok a legveszélyeztetettebbek közé tartoznak (Connor 2009). A S. josikaea kiemelt figyelmet élvez; törvény által védett Ukrajnában és Romániában is (Diduch 2009; Dihoru és Negrean 2009), szerepel a Kárpátok Veszélyeztetett Fajainak Listáján (Tasenkevitch 2003), az IUCN Veszélyeztetett Fajok Vörös Listáján (Bilz 2011) és az Európai Élőhely Direktíva II. és IV. függelékében (Council of the European Communities 1992).

A megfelelő természetvédelmi kezelési tervek kialakításához alapvető a veszélyeztetett és ritka fajok fennmaradt állományainak, ezek méretének és élőhelyének pontos ismerete. A S. josikaea elterjedési adatainak java része egy évszázaddal ezelőttről származik (Fekete és Blattny 1913), ezt követően csak az Ukrajnai-Kárpátok állományainak szisztematikus felkeresése és megerősítése történt meg az utóbbi években (Kohut 2013). Az Erdélyi-szigethegységi populációk évszázados adatainak megerősítése fontos és sürgős feladat egy olyan időszakban, amikor e területen az erdei növényzetre ható antropogén befolyás folyamatosan növekszik (Ioras és Abrudan 2006). 
A diszperz elterjedésű, kisméretű populációk között jelentős reproduktív izoláció alakulhat ki. Ennek következtében a faj fennmaradása a kisméretü állományok egymástól független fennmaradásától függne (Allendorf et al. 2013). A S. josikaea állományai közötti rokonság és az egyes populációk genetikai diverzitásának meghatározása választ adhat arra a kérdésre, hogy valójában milyen kapcsolat maradt fenn a populációk között, illetve bebizonyosodik-e az állományok korábban vélt izoláltsága. Vizsgálatainknak végül fontos természetvédelmi konzekvenciái lehetnek. 


\section{Célkitüzés}

A Syringa josikaea biogeográfiájának megismeréséhez az első lépés a populációk aktuális elterjedésének feltárása. A molekuláris evolúciós munkákhoz pedig ki kell dolgozni taxonspecifikus molekuláris markereket. A történeti biogeográfia talán legfontosabb kérdése e taxonnál, hogy a földtörténeti események során mikor vált el a közép-európai $S$. josikaea a kelet-ázsiai rokonságától. A Kárpátok történeti biogeográfiájához és a faj természetvédelméhez értékes adatokat nyújt, ha sikerül feltárnunk a $S$. josikaea populációk közti genetikai variabilitásának mintázatát.

Munkám során a következő célokat tüztem ki:

1. A Syringa josikaea Erdélyi-szigethegységi elterjedésének aktualizálása, az állományok méretének felmérése és természetvédelmi szempontú értékelése.

2. Mikroszatellit markerek fejlesztése a Syringa josikaea genomjára, és variábilis DNS szakaszok keresése.

3. A Syringa josikaea rokonaitól való elválási idejének meghatározása molekuláris módszerrel.

4. A Syringa josikaea elterjedési területének (Ukrajnai-Kárpátok és az Erdélyi-szigethegység) részei közötti rokonsági, filogeográfiai viszonyok meghatározása.

5. A Syringa josikaea populációi közötti rokonsági viszonyok megállapítása, a kis egyedszámú populációk genetikai diverzitásának meghatározása. 


\section{Irodalmi áttekintés}

\subsection{A Syringa josikaea bemutatása}

\subsubsection{A Syringa josikaea alaktani leírása}

A Syringa josikaea három-négy méter magasra növő cserje vagy kisebb fa. Törzse alsó része gyakran elfekszik (1. ábra, A). Vegetatív növekedése erős, az idősebb tövek körül egyenes, jórészt ág nélküli hajtásokat hoz. Hajtásvégein egy rügy van. A levelek keresztben átellenesen állnak, rövid nyélbe keskenyedők vagy kerek vállból elliptikus-hosszúkásak, csúcsuk hegyes, esetleg röviden kihegyezett, fonákjuk fehéres vagy zöldesszürke, enyhén szőrös. A levél felülete fényes-börszerü, széle ép vagy enyhén fürészes. A virágzat az azévi hajtásokon fejlődik. A kocsányok és a hajtások aprón pelyhesek. A párta ibolyaszínü, karimája jóval rövidebb a csövénél, később felálló (1. ábra, B). A virágzás május végétől június közepéig tart (Jávorka 1925; Ciocarlan 2009).
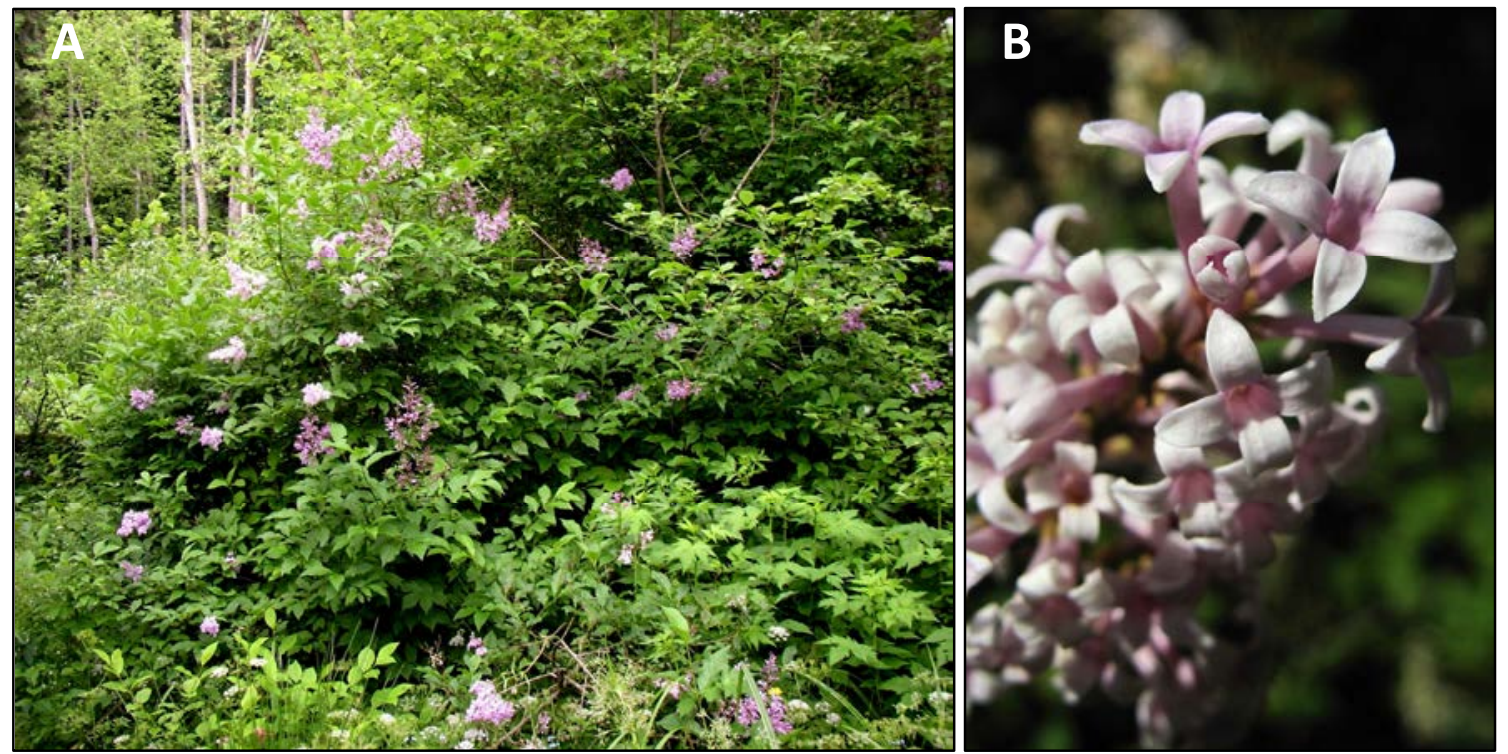

1. ábra: (A) A Syringa josikaea virágzó példánya (Zhdenijevo, Ukrajna, Kohut Erzsébet felvétele), és (B) a virágzat (BCE Budai Arborétum, saját felvétel)

\subsubsection{A Syringa josikaea élőhelye}

A $S$. josikaea az Ukrajnai-Kárpátok és az Erdélyi-szigethegység középhegységi régióinak bükkös és lucos övében terem (Fekete és Blattny 1913; Fodor 1974; Raţiu et al. 1984). Az UkrajnaiKárpátokban állományait 350-800 m tengerszint feletti magasságok között találjuk (Lendvay et al. 2012; Kohut 2013), míg az Erdélyi-szigethegységben 450-1000 m között terem (Blattny 1913; Lendvay et al. 2012).

Élőhelyei mindenütt humid klímájú patakpartok vagy lápos erdőfoltok. Patakparton élő állományainak példányai általában üde, hegyvidéki lombos erdőkben, bükkösökben, fenyőelegyes 
bükkösökben, rendszerint közvetlenül a víz szélén nőnek. E mellett a növény előfordul patakokat szegélyező magaskórósban, sziklagörgetegeken vagy fenyvesben is. A patak mentén élő populációknál néhány tíz, néhány száz méterenként fordul elő egy-egy példány. Az erdélyi populációk egyedei kizárólag így nőnek. Ezzel szemben az Ukrajnai-Kárpátokban a populációk többsége patakokat kísérő, hegylábakig érő síklápokban fordul elő, száraz időszakokban is nedvesen maradó égeresekben (Kohut és Höhn 2010; Kohut 2013). A S. josikaea ezeken a helyeken erős klonális növekedésével 10-100 $\mathrm{m}^{2}$-es sürü foltokat alkot, ahol az egyedhatárok meghatározása nehézkes.

\subsubsection{A Syringa josikaea rendszertani helyzete}

A Syringa josikaea az Oleaceae családba tartozik, amelynek rendszertani helyzete: Angiospermae / Eudicots / Core eudicots / Asterids / Lamiids / Lamiales (APG III 2009; Schäferhoff et al. 2010). Az Oleaceae családon belül a Syringa L. genusba, genuson belül pedig a series Villosae Schneider csoportba sorolják (Rehder 1945; Kim és Jansen 1998; Wallander és Albert 2000).

A taxonómiai tisztánlátást nehezíti a genus és az egyes fajok széles földrajzi elterjedése, a sok nemesített, akár interspecifikus hibrid fajta és a morfológiailag kétségtelenül hasonló fajok jelenléte. A fajok száma rendkívül változó egyes taxonok faji vagy alfaji szinten való elkülönítésétől függően; a különböző szerzők által faji szinten elkülönített taxonok száma eléri a 70-et (Chen 2008). A Syringa genus legfrissebb rendszerében, amely már a molekuláris taxonómiai eredményeket (Li et al. 2002) is figyelembe veszi, Fiala (2008) 21 fajt tart számon (1. táblázat).

A Syringa genus eurázsiai diszjunkt elterjedésü, a fajok a két európai kivételével Kelet vagy Közép-Ázsiában fordulnak elő (2. ábra). A két Európában őshonos faj a Syringa josikaea és a Syringa vulgaris. Bár e két faj elterjedési területe közel esik egymáshoz, sőt kis részben át is fedi egymást, a nemzetségen belül nem tekinthetők közeli rokonnak, és az élőhelyi jellemzőik is teljesen eltérőek. A S. josikaea hüvös, párás levegőjü, gyakran nedves környezetéhez képest a S. vulgaris meleg, száraz, sziklás élőhelyeken fordul elö a Balkán-hegységben, a Déli-Kárpátokban, legészakabbra pedig az Erdélyi-szigethegységben. A S. vulgaris a Syringa series Syringa-ba tartozik, és ennek a csoportnak a Syringa series Villosa-tól való távolságát jól jelzi, hogy a nukleáris genom alapján filogenetikailag a két series közé ékelődnek a Ligustrum-ok. A Ligustrum nemzetség Syringa-ba ágyazódásával a Syringa tehát parafiletikus, és a Syringa sensu lato tartalmazza a Ligustrum fajokat is (Függelék, F1. ábra, Li et al. 2002). 
1. táblázat: A Syringa fajok listája Fiala (2008) taxonómiai besorolása alapján.

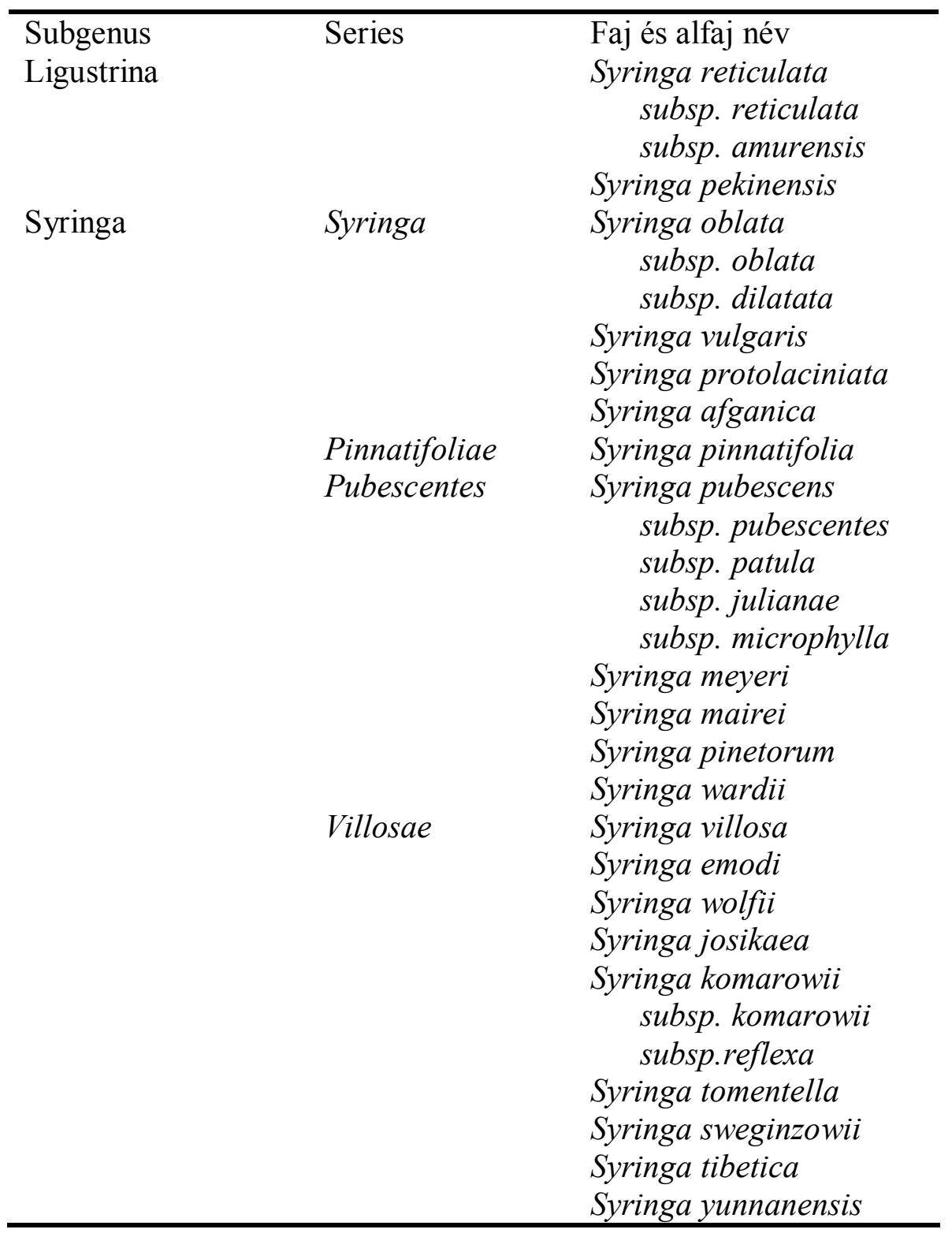

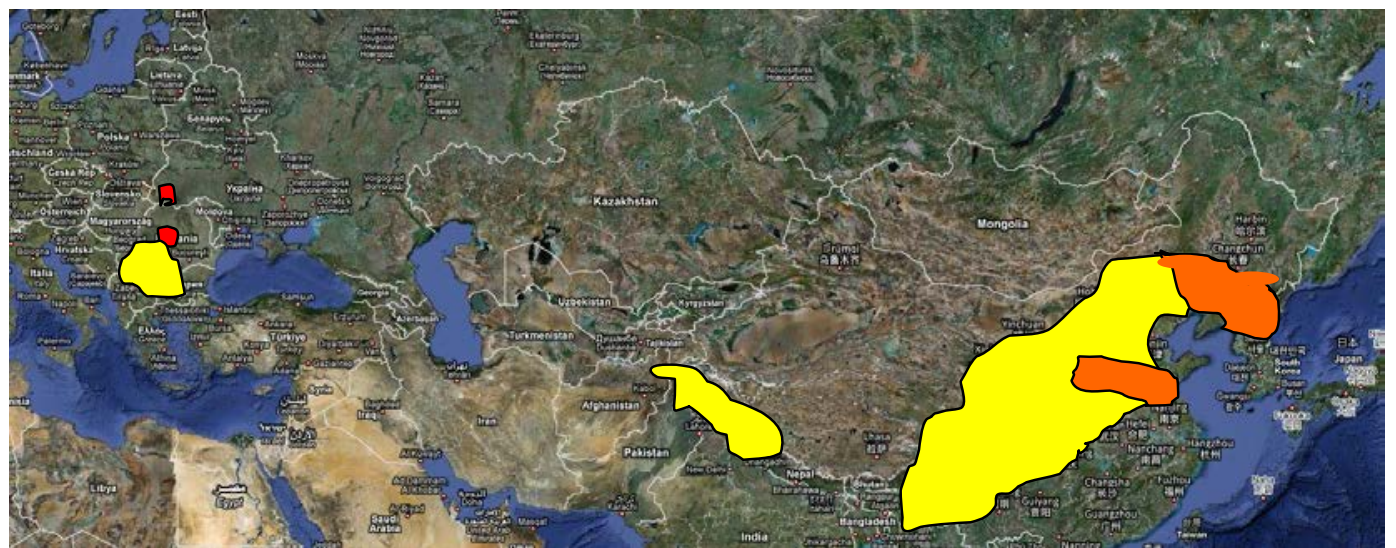

2. ábra: A Syringa genus diszjunkt elterjedése Eurázsiában (sárga színnel). A dolgozatban kiemelten jelentős fajok: Syringa josikaea (piros); Syringa villosa (narancs, délebbre); Syringa wolfii (narancs, északabbra). Saját ábra Fiala (2008) adatai alapján. 


\subsubsection{A Syringa josikaea szükebben vett rokonsága}

A S. josikaea faji önállóságát felfedezése után sokáig vitatták, és csupán a himalájai Syringa emodi Wallich ex Royle (amelyet pedig inkább a kelet-kínai Syringa villosa Vahl alfajának, mint önálló fajnak tekintettek) kertből származó vagy kivadult példányának tartották (Kanitz 1887; Borbás 1887; Sargent 1888; Flatt 1890). Ehhez - a S. josikaea S. emodi-hoz való nagyfokú hasonlósága mellett - hozzájárulhatott, hogy a $S$. josikaea leírása után évtizedekig a Jósika bárónétól származó sebes-menti adatán kívül más előfordulási adata nem volt széles körben ismert, és az ismertebb herbáriumi lapok is kultivált példányokról származtak például Nagyenyedről Fuss Mihálytól 1863-ból (Kanitz 1887).

Az a megállapítás, hogy a $S$. josikaea nem önálló faj, és a $S$. emodi-val azonos, legtöbbször csupán néhány élő vagy herbáriumi példány tanulmányozása alapján született. A két faj egymáshoz való nagyfokú hasonlóságát nem vonták kétségbe a 20. század legelejéig. Ekkor a kolozsvári Gulyás Antal (1907, 1910) részletes morfológiai és anatómiai vizsgálatok során kizárta a faji azonosságot a $S$. emodi-val, és megállapította, hogy a $S$. josikaea a $S$. villosa-hoz hasonlít leginkább. A $S$. josikaea-hoz és $S$. emodi-hoz is nagyon hasonló kelet-ázsiai elterjedésü $S$. wolfii Schneider-t, mint külön fajt csak Gulyás vizsgálatait követően, 1910-ban írták le. A jelenlegi legfrissebb nézetek szerint morfológiai hasonlóságuk alapján a $S$. wolfii csupán a $S$. villosa alfajának tekintendő (Chen et al. 2007).

Gulyás $(1907,1910)$ eredményeit, amelyek szerint a $S$. villosa (és a S. villosa-tól később elkülönített $S$. wolfii) áll legközelebbi rokonságban a $S$. josikaea-hoz, közel egy évszázaddal később megerősítették molekuláris és sokváltozós morfológiai adatelemzésen alapuló vizsgálatok. Kim és Jansen (1998) kloroplasztisz restrikciós fragmenthossz polimorfizmus (cpRFLP) alapján megállapította, hogy a vizsgált mintájukban a $S$. josikaea a $S$. wolfii egy mintájával áll legközelebbi rokonságban, és ezek egy csoportot alkotnak a $S$. villosa és a $S$. wolfii mintáival, hozzájuk képest a S. emodi rokonsági foka jóval alacsonyabb. Li et al. (2002) a nukleáris növényi genom riboszomális génjének ETS (external transcribed spacer) és ITS (internal transcribed spacers) DNS szekvenciái alapján megerősítette a $S$. villosa és $S$. wolfii közeli rokonságát és hozzájuk képest $S$. emodi különbségét. Hasonló eredményt hozott Li et al. (2012) vizsgálata, amelyben az ETS és ITS szekvenciákat analizálták kloroplasztisz szekvenciákkal kombinálva. E két utóbbi vizsgálatba sajnos nem vonták be a S. josikaea-t. A Syringa fajok rendszertanának tisztázására Chen (2008) herbáriumi példányok hajtás-morfológiájának sokváltozós vizsgálatával megállapította, hogy a $S$. villosa és $S$. wolfii nagyon nagyfokú hasonlóságot mutat a $S$. josikaea-val, előbbi két fajt két 
alfajnak, míg a S. josikaea-t, föként különálló elterjedési területére hivatkozva önálló fajnak javasolta.

Gulyás $(1907,1910)$ morfológiai-anatómai munkái, és az újabb molekuláris és morfológiai alapú munkák eredménye azonban nem került be a köztudatba, és a tudományos vagy tudományos ismeretterjesztő művekben máig a himalájai $S$. emodi jelenik meg mint a $S$. josikaea legközelebbi rokon faja (pl. Chopik 1970; Molnár V 1999, 2006; Dihoru és Negrean 2009; Bartha 2012).

\subsection{Fosszilis Syringa maradványok Európából és elméletek a Syringa josikaea származásával kapesolatban}

Mivel a Syringa-k nem domináns fajai a vegetációnak melyben előfordulnak és rovarmegporzásúak, ezért fosszilis maradványaik előkerülése nem várható nagyobb számban (Postigo-Mijarra et al. 2010). Ennek ellenére az elmúlt évszázad közepétől több helyen is találtak Syringa-ként azonosított fosszíliákat. Ezek a leletek meghatározták az egész nemzetség diszjunkt areájának kialakulásáról alkotott elméleteket, emiatt ez utóbbiakat a fosszilis maradványok áttekintésével együtt tárgyalom.

Mégha egy évszázaddal ezelőtt a $S$. josikaea leszármazási viszonyai nem is voltak pontosan ismertek (a himalájai Syringa emodi-t tartották ugyanis legközelebbi rokonnak a kelet-ázsiai $S$. villosa és $S$. wolfii helyett), ázsiai rokonaival szembeötlő diszjunkt elterjedése ismert volt. A $S$. josikaea földrajzilag távol élő rokonságára elsőként Ferdinand Pax (1898) adott magyarázatot, amely szerint a $S$. josikaea harmadkori reliktum faj, a pontusi flóra maradványa. Akik ismerték Pax munkáját, azoknak talán nem okozott meglepetést, hogy később találtak Syringa fosszilis maradványokat.

Az első Syringa fosszilis leleteket (levél lenyomatokat és termés maradványokat) a Weimar-Ehringsdorf (Thüringia, Németország) melletti édesvízi mészkőtufa üledékben fedezték fel (Vent 1955). A talált fajt Vent Syringa thuringiaca-nak nevezte el, a levél és termés morfológiájának vizsgálatát követően megállapította, hogy e növény a ma élő Syringa fajok közül a S. josikaea-hoz mutatja a legnagyobb hasonlóságot. Később az ehringsdorfi lelöhely közelében, Bilzingsleben (Thüringia, Németország) mellett elterülö mésztufa rétegekben talált Syringa maradványokat egyenesen $S$. josikaea-ként azonosították, igaz, ezt a lelőhelyet más kutatók tárták fel (Mania 2006; Mania és Mania 2008). Ezek a maradványok a negyedidőszak két meleg periódusából kerültek elö: a Holstein (Mindel-Riss) interglaciális és az Eemian (Riss-Würm) interglaciális időszakokból (a Pleisztocén korszak egyes időszakait az F2. ábra mutatja). 
Újabb előkerült Syringa maradványok Skoflek István nevéhez füződnek, melyeket Magyarország két pontjáról, Vértesszőlősről és Mónosbélről származó rétegekben azonosított (Skoflek 1968, 1990). A Vértesszőlősről előkerült Günz-Mindel interglaciálisból és a Mindel glaciális interstadiálisaiból származó maradványokat két fajként Syringa pleistocenica-nak és Syringa pannonica-nak írta le. Előbbit a ma élő fajok közül a Syringa amurensis-hez találta leghasonlóbbnak, míg az utóbbit a Syringa persica-val találta legközelebbi rokonnak a levél és termések morfológiája alapján. Ezeknek a fajoknak a pollenje is kimutatható volt a KözépsőPleisztocén melegebb időszakaiban (Járai-Komlódi 1990). A mónosbéli Riss-Würm interglaciálisból származó leleteket Syringa bükkensis és Syringa hungarica néven írta le. Ezeket a fajokat túl különbözőnek találta a többi (fosszilis vagy mai) Syringa fajtól, emiatt nem tudta meghatározni, hogy pontosan melyikkel legnagyobb a hasonlóságuk.

Skoflek (1968) szerint ezek a Syringa fajok a környezetükben talált ősnövényzet alapján mediterrán, de legalábbis atlantikus klímaigényűek voltak; megfelelő klímájú időszakokban elterjedési területük kiterjedhetett, számukra kedvezőtlenebb időszakokban pedig visszahúzódtak refugiális élőhelyekre, míg a Pleisztocén lehülésekkel járó szárazodások során a Németországban fosszíliák alapján leírt Syringa taxonokkal együtt ki nem haltak. Az egyes fajoknak legközelebbi közös ősei (akár a ma is élö) ázsiai fajok lehettek, azaz a kihalt európai fajok eurázsiai elterjedésü taxonok áreájának feldarabolódása után alakulhattak ki, ellentétben azzal a lehetőséggel, hogy Európában diverzifikálódtak volna ezek a fajok.

Andreánszky Gábor (1968) egy Szarmata (Középső-Miocén) korú Bánhorvátiból (Északi-Középhegység) származó fosszilis Syringa leletet azonosított, aminek a S. josikaea-hoz való hasonlósága miatt a Syringa paleojosikaea nevet adta, bár részletesebb vizsgálattal nem támasztotta alá a fajok közti rokonságot posztumusz megjelent publikációjában. Ez a fosszilis lelet viszont erősítette azt a nézetet, mely szerint a $S$. josikaea harmadkori reliktum.

Két évtizede került elő fosszilis Syringa pollen az Ibériai-félsziget keleti részéről (Abric Romaní, Katalónia, Spanyolország; Burjanchs és Julià 1994), amely a Syringa genus egyetlen nyugat-európai fosszilis maradványa. A közelebbről nem meghatározott rendszertani kategóriájú pollen maradványok a Késő-Pleisztocénből származnak, ami azt jelentheti, hogy egészen az utolsó eljegesedésekig fennmaradhatott Syringa faj ezen a területen. A Syringa-nak ez az izolált előkerülése meglepő, és mivel a Syringa és a Ligustrum pollenje könnyen összetéveszthető, ezért ennek az előfordulásnak a valódiságát további leleteknek kellene megerősíteniük (Postigo-Mijarra et al. 2010).

Egy, a $S$. josikaea reliktum származásával ellentétes elmélet még a Syringa fosszilis leletek előkerülése előtt jelent meg. E szerint a $S$. josikaea nem természetes módon létrejött önálló faj, 
hanem egy ázsiai taxon Ázsiából nyugatra vándorolt népek által Európába magukkal hozott példányainak leszármazottja. Így a $S$. josikaea csupán egy archeofiton eleme lenne a Kárpátoknak. Ezt az elméletet Susan D. McKelvey, a 20. század első felének jelentős Syringa szakértője orgonákról szóló monográfiájában tárgyalta részletesen, bár ő maga nem támogatta az elméletet (McKelvey 1928). Ennek az elméletnek a megerősítése vagy cáfolata nem jelent meg a szakirodalomban, nyolcvan évvel McKelvey munkáját követően Fiala (2008) szerint ennek a kérdésnek a tisztázása további tudományos munkát igényel.

\subsection{Eurázsia flórájának alakulása a Kainozoikumban, eurázsiai diszjunkciók és Tercier maradványfajok Európában}

A Föld ma ismert növénycsaládjai és nemzetségei a Kainozoikum elején kezdtek kialakulni. Ekkor az északi féltekén boreotropikus flóra jött létre a mainál jóval melegebb és nedvesebb klíma és a sarkvidéki jégsapka hiányának hatására. A kontinensek tektonikus mozgása során az Oligocén elejére bezárult az Európát és Ázsiát elválasztó, Tethyst és Jeges-tengert összekötő Turgai-tenger, és innentől Eurázsia területe átjárhatóvá vált az élővilág számára a két, korábban különálló földrész között (Tiffney és Manchester 2001; Xiang és Soltis 2001). A növényfajok elterjedési területe és a fajkicserélődés Eurázsia keleti és nyugati fele között a Miocén hőmérsékleti csúcsa (Közép-Miocén klíma optimum, 15-17 millió éve) során érhette el maximumát (Zachos et al. 2001; Xiang et al. 2005). Ezt az időszakot a Miocénben enyhe hőmérséklet csökkenés (10 millió évvel ezelöttig) és stabil hőmérséklet követte a Miocén-Pliocén átmenetig (5,3 M év). Európára ekkor melegkedvelő és örökzöld fajok voltak jellemzők (Tiffney és Manchester 2001). A Pliocénben a mainál melegebb és nedvesebb klíma uralkodott 3,2 millió évvel ezelőttig, amikor a klíma fluktuálni kezdett, és megkezdődött a lehủlési folyamat, amely a negyedidőszaki jégkorszakokba vezetett (Thompson és Fleming 1996; Zachos et al. 2001).

A Pliocénben már a hőmérséklet és csapadék mennyiség is limitáló tényezővé vált a növényzet számára (Tiffney és Manchester 2001). A Pliocén során Eurázsia különböző mérsékelt égövi területeit többféle eltérö vegetáció borította, jelen voltak lombhullató erdök, kevert lomhullató-tülevelü erdők, tűlevelű erdők és sztyeppnövényzet is előfordult (Thompson és Fleming 1996; Salzmann et al. 2008).

Eurázsia vegetációjának változását elsősorban hőmérséklet-ingadozások határozták meg, amelyek erősen befolyásolták egyes területek csapadék-ellátását: a hőmérséklet csökkenésével a sarki jégsapkák kiterjedtek, ami a tengerek vízszintjének csökkenésével járt, evvel pedig a globális csapadékeloszlás megváltozott (Willis és McElwain 2002). A vegetáció változásának másik fő 
befolyásoló tényezője kontinentális léptékben a Tibeti-fennsik és Himalája tektonikai kollíziót követő felgyürődése (fő szakasza 20-8 millió évvel ezelött történt), amely következtében a tőle északra fekvő területek elszárazodtak, míg délre és keletre csapadékgazdag monszun éghajlat alakult ki (Harrison et al. 1992; Wang et al. 1999; Zachos et al. 2001; Zhisheng et al. 2001). A későbbi klíma-ingadozásokat viszont már nem befolyásolta érdemben e hegyláncok további felgyürődési folyamata (Huntley 1993). A Kainozoikum során a vegetáció változása Európa egyes területeire bontva még nem pontosan ismert.

A Miocén és Pliocén időszakokra jellemző fás növényfajok jelentős része kihalt a Pleisztocén eljegesedések során Európában, elsősorban annak északi és nyugati részein (Mai 1989). A növényzetnek a túléléshez az északról érkező hideg elől dél-európai refúgiumokba kellett eljutniuk, amihez viszont át kellett jutniuk a kelet-nyugati irányú hegyláncokon, ott pedig meg kellett küzdeniük a Mediterráneumban az eljegedesedések során jellemző erős szárazsággal (Huntley 1993). A kihalási folyamat nagyobb részt végigment a Pleisztocén első lehűlése, a Gelasi korszak (más elnevezés szerint a Praetegelen és Tegelen korszakok, 2,6-1,8 millió éve) folyamán, és ezt követően csupán néhány faj halt ki (pl. Staphylea, Celtis, Pterocarya, Willis és Niklas 2004; Magri 2010; Postigo-Mijarra et al. 2010). A máig fennmaradt fásszárú fajok elsősorban hidegtűrésükben térnek el a kihalt fajoktól (Svenning 2003), de szárazságtűrésükben is felülmúlják a kihalásra jutott harmadidőszaki fajokat Európában (Milne és Abbott 2002).

A szakirodalomban gyakran megjelenik a harmadkori vagy Tercier reliktum (Tertiary relict) kifejezés, ennek pontos értelmét ritkán határozzák meg. Tercier alatt a Kainozoikum Paleogén és Neogén korszakát értjük, de a Tercier a földtudományban ma már nem elfogadott földtörténeti kor megnevezés, ellenben a botanikai szakirodalomban manapság is használatos. A Tercier reliktum kifejezés sok esetben egy tágabb értelmezést kap, amely szerint Tercier reliktumnak tekintendők azok a taxonok, amelyek egy, a Tercierben (Paleogén vagy Neogén időszak során) nagyobb elterjedési területü taxon leszármazottai, és nem veszik tekintetbe a leszármazott taxonok későbbi area mozgásait (pl. Wen 1999; Milne és Abbott 2002). Ez a felfogás általában interkontinentális diszjunkt elterjedésű taxonok (pl. Ázsia-Észak-Amerika) vizsgálatakor jelenik meg, ahol a jelen taxonok elterjedési területe evidens módon jóval szükebb, mint a korábban létezetteké. Egy másik, szükebb értelmezést európai fajokra határozott meg Denk et al. (2001); eszerint azt tekintjük Európában Tercier reliktum fajnak, amely egy, a Tercierben kiterjedt előfordulású közel rokon taxon leszármazottja, és amelynek elterjedési területe ma csak kisméretü, izolált refúgium területekre korlátozódik. Európában a szükebben vett értelmezés szerinti meghatározás alapján is Tercier reliktum fajok Dél-Európára koncentrálódnak (2. táblázat), mérsékelt éghalatú területeken 
reliktum elterjedési területek nagyon ritkák és felfedezésük (genetikai alapon) szenzáció értékü (pl. Valtueña et al. 2012).

2. táblázat: Néhány európai Tercier reliktum fásszárú faj elterjedése. Adatforrás: Feng et al. (2005); Calleja et al. (2008); Filipova-Marinova et al. (2010).

\begin{tabular}{ll}
\hline Fajnév & Elterjedési terület \\
\hline Aesculus hippocastanum & Kelet-Balkán-Fsz. \\
Cercis siliquastrum & Mediterráneum \\
Fagus orientalis & Kelet-Balkán-fsz., Kis-ázsia, Kaukázus \\
Laurus nobilis & Közép-Mediterráneum (Szicília) \\
Liquidambar orientalis & Kis-Ázsia \\
Platanus orientalis & Kelet-Mediterráneum, Balkán-fsz., Kis-Ázsia \\
Prunus laurocerasus & Kis-Ázsia \\
Prunus lusitanica & Ibériai-félsziget \\
Pterocarya fraxinifolia & Kelet-Balkán, Kis-Ázsia, Kaukázus \\
Rhododendron ponticum & Kis-Ázsia \\
Zelkova abelicea & Kelet-Mediterráneum (Kréta) \\
Zelkova carpinifolia & Kis-Ázsia \\
Zelkova sicula & Közép-Mediterráneum (Szicília) \\
\hline
\end{tabular}

A Tercier reliktum fajok evolúciójában a harmadidőszaki kontinens mozgások illetve harmad- és negyedidőszaki klímafluktuációk következtében bekövetkezett kihalások során létrejövő area diszjunkciók játszották a legnagyobb szerepet, ezek a diszjunkciók az interkontinentális léptéket is elérheik (Raven 1972; Wen 1999; Xiang és Soltis 2001; Milne és Abbott 2002; Milne 2006).

Az ilyen diszjunkciók az észeki-féltekén lehetnek Eurázsia nyugati része - Észak-Amerika keleti része, Kelet-Eurázsia - Nyugat-Észak-Amerika illetve Eurázsia keleti - nyugati részei között. Az óceánokkal elválasztott kontinensek közti area diszjunkciókhoz képest kevésbé látványosak és kevésbé kutatottak az Eurázsián belüli, Európa és Kelet-Ázsia közötti diszjunkt elterjedési területek (Wood 1972). Sőt, ezeket némely esetben nem is számítják az interkontinentális diszjunkciók közé, holott a távolságaik esetenként nagyobbak, mint az óceánokkal elválasztott diszjunkciók közöttieké (Thorne 1972).

Érdekes jelenségként az Oleaceae családban több Eurázsia keleti és nyugati része közti független diszjunt elterjedésü rokonság is kialakult (Green 1972). A már említett Syringa-kon kívül így az európai elterjedésü Ligustrum vulgare kelet- és közép-ázsiai fajokkal rokon, a Balkánfélszigeten élő Forsythia europaea közép-ázsiai rokonságú, a Kelet-Mediterránban élő Fontanesia phillireoides legközelebbi rokona Közép-Kínában él, a Fekete-tenger keleti partvidékén elterjedt Osmanthus decorus rokonsága Kelet-Ázsiában található (Green 1972; Kim 1998, 1999; Guo et al. 2011). 
A diszjunkt elterjedési területek kialakulási idejének meghatározásában áttörést hoztak a molekuláris óra analízisek szofisztikált statisztikai módszerei (Renner 2005). Ezekben az analízisekben evolúciós törzsfák elágazásait és a leszármazási ágak korát datálják molekuláris óra fosszília alapú kalibrációjával. Biogeográfiai események idejének meghatározásában divergencia idők molekuláris óra analízissel történő megállapítása azért jelentős, mert a morfológiai sztázis jelensége következtében a diszjunkt elterjedésű leszármazott taxonok évmilliókon keresztül morfológiailag rendkívül hasonlóak maradhatnak, így morfológiai hasonlóságok alapján a leszármazási idők csupán pontatlanul lesznek megbecsülhetőek. A molekuláris vizsgálatok és molekuláris óra analízisek sok esetben jelentősen régebbi divergencia időt állapítottak meg annál, mint amit a morfológiai hasonlóságok alapján feltételeztek (Milne és Abbott 2002).

Eurázsia keleti és nyugati széle közti diszjunkciók közül eddig néhánynak ismerjük csak az idejét, ezekből kirajzolódik, hogy nagyon széles időintervallumban jöttek létre ezek a diszjunkt areák (0,5-55 millió év között, 3. táblázat).

3. táblázat: Eurázsiai diszjunkciók kialakulási ideje molekuláris óra alapú vizsgálatok alapján a diszjunkciók kialakulási idejének sorrendjében

\begin{tabular}{lll}
\hline $\begin{array}{l}\text { Eurázsiai diszjunkt } \\
\text { genus }\end{array}$ & $\begin{array}{l}\text { Diszjunkció kialakulása } \\
\text { (millió év) }\end{array}$ & Hivatkozás \\
\hline Forsythia & 0,5 & Kim 1999 \\
Coriaria & 2 & Yokohama et al. 2000 \\
Scopolia & 2,7 & Tu et al. 2010 \\
Epimedium & $0,5-4,2$ & Zhang et al. 2007 \\
Scabiosa & $2,3-6,6$ & Carlson et al. 2012 \\
Meconopsis & 12,8 & Valtueña et al. 2012 \\
Aesculus & 15 & Xiang et al. 1998 \\
Cornus & $13-25$ & Xiang et al. 2005 \\
Spiraea & 20 & Zhang et al. 2006 \\
Cercis & 46 & Donoghue et al. 2001 \\
Liquidambar & 55 & Donoghue et al. 2001 \\
\hline
\end{tabular}

\subsection{Populációgenetikai vizsgálati módszerek és vizsgálatok a Syringa josikaea rokonainál}

Populációk genetikai diverzitásának és rokonságának megállapításához szükség van megfelelően variábilis DNS szakaszokra kiegészítve vagy helyettesítve megbízhatóan működő molekuláris markerekkel. Amíg állatok esetében nem problematikus fajon, sőt populáción belül is 
informatív változékonyságú DNS szakaszokat találni általánosan használható PCR primerekkel (pl. mitokondriális citokróm-c oxidáz I-es alegysége, Folmer et al. 1994; mitokondriális citokróm $b$ gén, Kocher et al. 1989), addig növények esetében idő- és munkaigényes lehet megfelelően variábilis DNS szakaszokat és markereket találni, mely során az adott taxonra alkalmazható specifikus PCR primerek tervezésére is gyakran szükség van.

\subsubsection{Nukleotid sorrenden alapuló DNS markerek}

Zárvatermők esetében populációk rokonságának, fajon belüli filogeográfia feltárásához általában a kloroplasztisz nem kódoló DNS szakaszait (intronok, intergénikus régiók: IGS), a nukleáris genomi régiók közül pedig alacsony kópiaszámú gének (low-copy nuclear genes, LCNG) intronjait vagy a riboszomális RNS-eket kódoló gének nem kódoló szakaszainak szekvenciáit vizsgálják.

A kloroplasztisz genom alacsony variabilitása miatt számos, a zárvatermőkön belül gyakorlatilag univerzálisan alkalmazható primer ismert (pl. Taberlet et al. 1991; Demesure et al. 1995; Shaw et al. 2005, 2007). Azonban pontosan e szekvenciák alacsony variabilitása miatt szükség lehet több lókusz variabilitásának tesztelésére, amire az adott fajra nézve informatív régiót sikerül találni. A kloroplasztisz általában anyai öröklődésü a zárvatermökben, ami különösen előnyössé teszi őket fajok leszármazásának és múltbeli terjedésének vizsgálatára. A $S$. josikaea-ban azonban a kloroplasztiszt egy korábbi tanulmány kétszülős öröklődésűnek találta (Liu et al. 2004).

Az alacsony kópiaszámú gének közül több olyan is létezik, amelyet a vizsgált taxonok jelentős részében informatívnak találtak (Calonje et al. 2009). Hátrányuk ezeknek, hogy néhány kivétellel (pl. Li et al. 2008) a nagy variabilitásuknak köszönhetően taxon-specifikus PCR primerekre van szükség hozzájuk, továbbá alkalmazásukat bonyolítja, hogy a kétszülős öröklődésük miatt a PCR-temékek klónozására lehet szükség szekvenálás előtt heterozigóta egyedek előfordulása esetén.

A riboszomális gének a nukleáris genom speciális öröklődésủ génjei közé tartoznak. Mivel a riboszomális RNS-ek meghatározóak a sejtek élete szempontjából, nagy mennyiségben van rájuk szükség, így nem elég egy vagy néhány lókuszban jelen lenniük a genomban (a fehérjékkel ellentétben, ahol az mRNS egyszeri transzkripciójának hatása felerősödhet többszöri transzlációval). Ez genomonként több száz vagy ezer tandem elhelyezkedő kópiát jelent, melyek a együttes evolúció (concerted evolution) folyamatának során egyeden belül uniformizálódnak (részletesen lásd Eickbush és Eickbush 2007). A riboszomális alegységeket kódoló gén-szakaszok közötti, illetve az azokon kívül eső, a tandem ismétlések közti belső és külső átíródó szakaszokat szokták használni (external transcribed spacer és internal transcribed spacers, ETS és ITS) 
megfelelő variabilitásuk miatt. Az ITS előnye, hogy ismertek univerzálisan használható primerjeik (pl. White et al. 1990), az ETS taxon-specifikus primereket igényel (Baldwin és Markos 1998). Hátrányuk, hogy gyakran egyeden belül is variabilitás tapasztalható, és, hogy nagy az esélye homoplázia kialakulásának (Álvarez és Wendel 2003).

Munkám kezdetekor Syringa-k esetében ITS és ETS szekvenciák használatára már volt szakirodalmi tapasztalat (Li et al. 2001, 2002), kloroplasztisz és LCNG szekvenciákat korábban nem alkalmaztak (Li et al. 2012 kloroplasztisz szekvenciákat is vizsgáló publikációja később jelent meg).

\subsubsection{Hosszpolimorfizmuson alapuló DNS markerek}

Markerek használatakor DNS variabilitást vizsgálnak a konkrét szekvencia-eltérések ismerete nélkül. A Syringa taxonok esetében több vizsgálat is készült DNS markerek felhasználásával, amelyeknek célja kertészeti változatok és hibridek rokonságának kiderítése volt. Ezek két domináns, random primer bekötődésű marker típus RAPD (random amplified polymorfic DNA, Kochieva et al. 2004; Marsolais et al. 1993; Melnikova et al. 2009; Xinlu et al. 1999) vagy ISSR (inter simple sequence repeat, Rzepka-Plevneš et al. 2006) felhasználásával készültek. A RAPD és ISSR markerek mára kevéssé népszerüek gyenge ismételhetőségük és pontatlanságuk miatt, számos folyóirat nem is fogadja már el az ezekkel a technikákkal készült kéziratokat.

Populációgenetikai, nemesítési, természetvédelmi genetikai vizsgálatokhoz a nukleáris mikroszatellit markereket használják leggyakrabban (Powell et al. 1996; Frankham et al. 2002; Guichoux et al. 2011). A mikroszatellitek 2-6 bp hosszú DNS szekvencia motívumok tandem ismétlődéséből állnak, amelyek alléltól függően különböző számú ismétlődést tartalmazhatnak, így a különböző allélek a mikroszatellitek hossza alapján azonosíthatóak. A mikroszatellit markerek előnye, hogy kodominánsak, nagy felbontásúak és - azonos müszereken végezve - jól ismételhetők, emiatt például az igazságügyi genetikai vizsgálatokhoz is mikroszatelliteket alkalmaznak (cf. FBI Laboratory 2013). A módszer hátránya viszont, hogy taxonspecifikus (általában legalább azonos genusból származó fajokra tervezett) primereket igényel. Mikroszatellit markerek fejlesztése többféle elven történhet melyek közül napjainkban is gyakran idézett például: FIASCO protokoll (Zane et al. 2002), Lian et al. (2006) összetett mikroszatelliteken alapúló markerfejlesztési módszere (technique for isolating compound microsatellites,) vagy a piroszekvenálás adatok alapján történő mikroszatellit marker fejlesztés (Csencsics et al. 2010). Ám bármilyen módszert is alkalmazunk, megfelelően variábilis markerek megtalálása időigényes lehet (Squirrell et al. 2003; Schoebel et al. 2013). 
Nukleáris mikroszatelliteket nem alkalmaztak korábban a Syringa genusban. Közelebbi rokon fajok közül is csupán két fajra, az Olea europaea-ra és Ligustrum ovalifolium-ra terveztek primereket. De la Rosa et al. (2002) az általuk az Olea europaea genomjára tervezett mikroszatellit markerek közül kettőt amplifikálhatónak és variábilisnak találtak a Syringa vulgaris két egyedét vizsgálva. Kodama et al. (2008) Ligustrum ovalifolium-ra tervezett mikroszatellit primereinek más fajokra való alkalmazhatóságát nem vizsgálták (M. Maki, Tokohu University; személyes közlés), de mivel a Ligustrum fajok filogenetikailag a Syringa fajai közé ékelődnek (Li et al. 2002, 2012), ezért ezek a markerek hordozzák annak a lehetőségét, hogy Syringa fajokban is alkalmazhatóak legyenek.

\subsection{A Syringa josikaea Erdélyi-szigethegységi elterjedésének szakirodalma}

Ebben a fejezetben a $S$. josikaea felfedezésétől kezdve tekintem át a faj elterjedési adatainak irodalmát az Erdélyi-szigethegységre vonatkoztatva. Az Ukrajnai-Kárpátok elterjedési adatai hasonló részletességgel szerepelnek Kohut Erzsébet doktori értekezésében (2013), így ezek részletekbe bemenő áttekintésétől eltekintek, róluk csupán egy táblázatos összefoglalást adok e szakasz végén. A két elterjedési terület szakirodalmi adatai együtt szereplnek Lendvay et al. (2012) munkájában.

Az Erdélyi-szigethegység esetében az elterjedési adatok áttekintésekor sok ellentmondásra, bizonytalanságra derült fény. Ezek oka - amint az az áttekintés végére látható lesz -, hogy a korábban elfogadott elterjedési adatok között több is félreértés, félrefordítás vagy elírás útján keletkezett, más előfordulási adatok megerősítésre szorultak, mert azok a frissebb irodalomban elnagyoltan és pontatlanul szerepeltek. Mindezeknek a felderítésére, továbbá közel két évszázad elterjedési adatainak kritikai áttekintésére csupán a teljes szakirodalomnak a lehető legrészletesebb áttanulmányozásával tehettem kísérletet.

Az elterjedési adatok áttekintéséhez felhasználtam az összes fellelhető szakirodalmat, amelyek érdemi információt tartalmaznak a $S$. josikaea elterjedéséről a romániai áreában. Ezt kiegészítendő átnéztem a budapesti Magyar Természettudományi Múzeum Növénytárának (Index Herbariorum kód: BU), a bukaresti Román Akadémia Biológiai Intézet (BUCA) és a kolozsvári Babes-Bolyai Tudományegyetem Botanikus Kert (CL) herbáriumának anyagát is.

Az elterjedési adatokat azok megjelenésének időpontja szerint szakaszokra osztva tekintem át. 


\subsubsection{A Syringa josikaea felfedezése az Erdélyi-szigethegységben}

A Syringa josikaea-t a tudomány számára Joseph von Jacquin, bécsi professzor közölte, miután Jósika báróné gróf Csáky Rozália a kolozs megyei Sebes-patak közelében találta a növényt, és eljuttatta azt hozzá (Radnóti 1888). Jacquin a faj tudományos nevét Jósika báróné tiszteletére adta, és a természetvizsgálók és orvosok 1830. szeptember 20-i hamburgi gyülésén mutatta be (Jacquin 1831a,b). Azonban nem Jacquin volt az első botanikus, aki a S. josikaea-t felfedezte az Erdélyi-szigethegységben: korábban már Baumgarten János is megtalálta, és el is nevezte az új fajt, de leírása nem vált elfogadottá. Szerepét a $S$. josikaea történetében csak egy századdal később sikerült többé-kevésbé tisztázni.

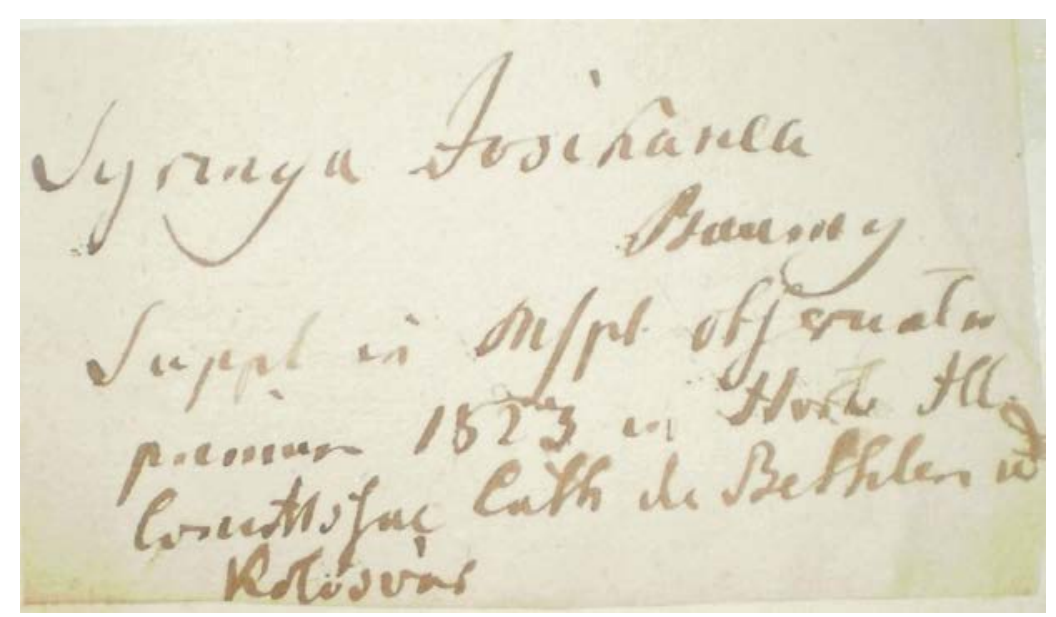

3. ábra: A legkorábbról származó Syringa josikaea herbáriumi példány etikettje az évszám szerint 1823-ból való. Származási helye (amennyire kivehető) Bethlen Katalin kolozsvári kertje. Külön érdekesség, hogy fajnévként a Joseph Jacquin által 1830-ban publikált Syringa josikaea, a faj leírójaként viszont „Baumg.” szerepel. Ez azt is jelenti, hogy ez az etikett legalább hét évvel a gyüjtés után került a herbáriumi lapra. A herbáriumi lap minden bizonnyal Baumgartentől származik (cf. Gombocz 1935, 1936). (Kolozsvár, Babes-Bolyai Tudományegyetem Botanikus Kert herbáriuma [CL], saját felvétel)

Baumgarten János 1823-ban fedezte fel a növényt Kolozsváron Bethlen Katalin grófnő kertjében, ahogy ez Baumgarten Sadler Józsefhez írt 1836-os leveléből és herbáriumi gyüjteményéből kiderül (3. ábra; Gombocz 1935, 1936). Baumgarten felismerte a növény faji újdonságát, és megtudta, hogy az eredetileg Jósika báróné sebes-völgyi birtokáról származott. Az élőhelyet ezután valószínüleg személyesen is felkereste. (Jósika báróné pedig valószínüleg az ő javaslatára juttatta el a növényt Jacquinhoz, vagy legalábbis ő hívta rá fel a báróné figyelmét.) Baumgarten nevet is adott az új fajnak; a Syringa vincetoxicifolia Baumgarten herbáriumi lapjain tünik fel, és Baumgarten kéziratára hivatkozva Steudel Nomenclatur botanicusa (1840-1841) közli először, mint a $S$. josikaea szinonimáját. Baumgarten herbáriumi lapjain a növény hol $S$. 
vincetoxicifolia, hol S. josikaea, hol pedig egyszerre mindkét néven szerepel (F3. ábra). Baumgartennek a Fuss Mihály (1846) által kiadott posztumusz múvében, a Mantissa negyedik kötetében pedig már nem említik a S. vincetoxicifolia-t. Borbás (1882) szerint feltehetően Fuss hagyta el Baumgarten szinonimáját, és a fajt az akkor már elfogadott Syringa josikaea néven nevezi.

\subsubsection{Az első előfodulási adatok 1830-tól 1880-ig}

A S. josikaea leírása után évtizedekig a Jósika bárónétól származó „An Felsen bei Sebes im Comitat Clausenburg in Siebenbürgen” adatán (Reichenbach 1830-1832) kívül más előfordulási adat nem volt a botanikusok széles körében ismert. A 1800-as évek közepe táján megjelent flóramüvek közül Baumgarten Mantissa-jának negyedik kötetében előfordulásként csak „Inter pagos Székelyö et Nagy-Sebes” (sic!) „in loco Henz dicto, montoso lapidoso juxta fluvium Sebes” szerepel (Fuss 1846). Fuss Mihály (1866) erdélyi flórájában már a következő helyekről említi: Székelykő, Csucsa, Nagy-Sebes. Fuss részben ezt a művét megalapozó Herbarium Normale Transsilvanicumjában (1863) feltünteti ezeknek a forrásoknak a származását is: „Székelyö und Nagy-Sebes (Baumgarten), Csucsa (Schur)”. A Székelyö és Székelykő adatok nyilvánvalóan a Sebes-patak menti Székelyó (ma: Sâcueu) falu nevének elírásából, vagy helyi formájából, majd ennek félreértéséből származnak. A botanikailag különben érdekes Székelykő élőhelyei merőben mások, mint ahol a $S$. josikaea előfordul. Ez a később az orgonát eredeti élőhelyén vizsgáló botanikusok számára is rögtön feltünhetett, és rájöhettek a tévedésre. Bielz Ede Albert (1886) meg is jegyzi, hogy Fuss székelykői adata nyomtatási hiba. Többen ezután már nem is idézik ezt az adatot, kivéve Gulyás Antalt (1907), aki szerint a S. josikaea előfordul „mészkő törmeléken a Torockón a Székelykövön”.

Az 1866-os évben jelent meg Schur Ferdinánd Erdély-flórája is, ebben elterjedésként "Auf Felsen im Csutsaer Thale bei Sebes-Var” szerepel. Sebesvár (ma: Bologa) Székelyótól északra a Sebes-patak és a Sebes-Körös partján található.

Csak később vált ismertté a Landoz János által (1844; 1861-1863) felfedezett állomány „Melegszamos” helymegjelöléssel, bár Landoz ezt több alkalommal is publikálta, és herbáriumi lapot is gyüjtött belőle (pl. BP No. 132141 herbáriumi lap, 1856). Herbáriumba gyüjtötte Wolff (Gábor) „Sebes bei Klausenberg” (BP 132171 herbáriumi lap, 1851) és „Sebesvár et Melegszamos” (BP No. 132173 herbáriumi lap, 1854) helyekről. Egyik 1866-os flóramüben sem szerepel ezek ellenére a melegszamosi adat, holott Schur szoros kapcsolatban volt Wolffal és sok adatát neki köszönhette (Gombocz 1936). 
Janka Viktor (1854) is foglalkozott már ekkortájt az S. josikaea-val, megtalálja „Auf den hohen Felsen von Nagy Sebes”, ám herbáriumi lapjai még ennél is pontatlanabbul írják le a gyüjtés helyét: „,in ambulacris pr. Klausenberg Transylvaniae” (pl. BP No. 132148 herbáriumi lap, 1868). Elterjedésként említette Nagy-Sebest Baumgarten (Fuss 1846), Janka (1854) illetve (az ő adataik alapján) Fuss (1866) is. Baumgarten leírásából egyértelmüen kiderül (lásd: Gombocz 1935, Fuss 1846), hogy ő „Nagy-Sebes” elnevezésen a Sebes-völgyet érti, és a később Janka (1854) és Fuss (1866) által használt „Nagy Sebes” és „Nagy-Sebes” elnevezések valószínűleg - pontatlan megfogalmazással - szintén a sebes-völgyi Székelyó melletti Sebesvárra vonatkoznak. Nagysebesről (ma: Valea Drăganului) a S. josikaea egyetlen herbáriumi adata sem ismert. Nagysebes település nem a Sebes-völgyben, hanem attól néhány kilométernyire, a Kalota-hegység (Vlegyásza) vonulatának nyugati odalán található. Egy valóban Sebes-patak menti, Székelyó és Nagysebes közti terület (ahogy Fuss 1846 fogalmaz) földrajzilag értelmezhetetlen lenne. Egyéb müvekben (Reichenbach 1830-1832, Schur 1866) egyetlen lelőhelyként kétséget kizáróan a Sebesvölgy szerepel.

Véleményem szerint mindezek alapján a Nagysebesre vonatkozó adatok mind a Sebesvölgyre, Székelyó és Sebesvár közötti területre értendők. Erre a következtetésre jutott (bár véleményét nem fejtette ki részletesen) Soó Rezső is (1944a). Annak ellenére, hogy egyetlen konkrét megfigyelési adat sincsen Nagysebesről, előfordulási adatként napjainkig fennmaradt.

A faj 1830 környékén történt felfedezése után eltelt ötven évben tehát csupán az erdélyi Sebes-völgy, a hozzá közeli Csucsa, és Melegszamos vált ismertté mint előfordulási hely, utóbbi kettő konkrétumok nélkül, csupán egy-egy szóban.

\subsubsection{Az elterjedési terület feltárása az 1880-as években}

Az 1880-as években a florisztikai kutatások fellendülésével a S. josikaea ismert elterjedése is ugrásszerüen megnőtt. Simonkai Lajos (1881) szerint „újabb időben többen hasztalanúl keresték a Csucsa-sebesváraljai völgyben”, és ezt támasztja alá Feichtinger Sándor (1871), akinek nem sikerült itt felleni a $S$. josikaea-t. Simonkai (1881) „hosszas keresés és a vidék lakosainál való puhatolódzás után” „több szép példányban a Jósika-féle birtokterületen Csucsa mellett” megtalálta a növényt 1880-ban. Pontosabb helyleírást nem ad, valószínűleg vagy a Sebes-völgy Sebesvárhoz közeli részére gondol, és Csucsát mint közelebbi fontosabb közigazgatási központot szerepelteti, esetleg a Sebes-Körös Sebesvár és Csucsa közti kb. 10 km-es hosszának valamely pontjára gondol. Csucsai lakosokra hivatkozva közli, hogy Körösfeketetó mellett a Sebes-Kőrös partján is élnek e fajnak példányai „de ott is ritka”. 
A S. josikaea következőként elökerülő előfordulási helye Janka Viktor nevéhez füződik (1884, 1885). A lelőhelyet Baumgarten egy herbáriumi lapjáról veszi, és helységnévként Bujfunu-t határozza meg. Ezt a későbbi összefoglaló müvekben Thaisz (1909b) bizonytalanként említi, Blattny (1913), Fekete és Blattny (1913) pedig már nem is szerepelteti. Végül Péterfi Márton (1918) megfejti, hogy a herbáriumi lap félreolvasásáról lehetett szó: Janka csak Baumgartennek a növény gyüjtésére vonatkozó Maj-Junio szövegét olvasta félre, ez az adat tehát téves volt (4. ábra).

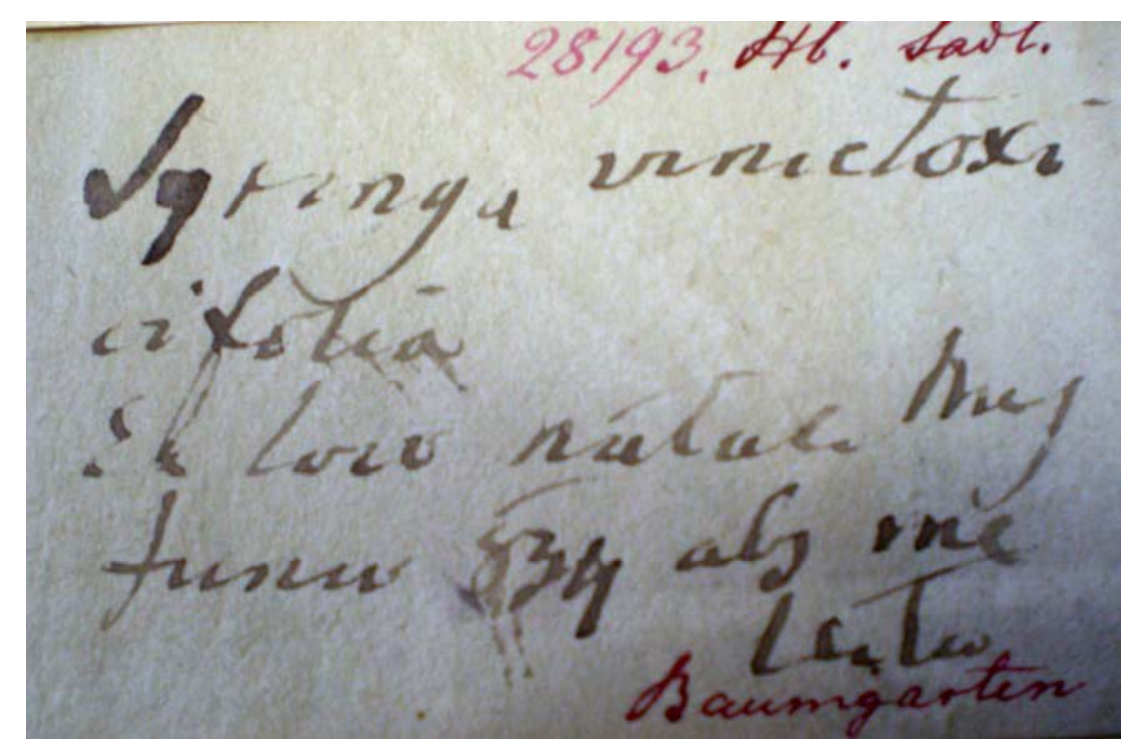

4. ábra: Egy Baumgarten János által gyüjtött Syringa josikaea példány herbáriumi példányának etikettje, melyen a fajt a szerző Syringa vincetoxicifolia-ként nevezi. E nehezen olvasható feliratú herbáriumi lap lehetett az, amelyen a virágzási időre vonatkozó „Maj-Junio” szöveget Janka Viktor félreolvasta „Bujfunu”-nak, és azt új, addig ismeretlen élőhelyként azonosította (cf. Janka 1884, 1885; Péterfi 1918). (Magyar Természettudományi Múzeum Növénytára [BP], No. 132149, saját felvétel)

Flatt Károly (1886) uradalmi tiszttartó 1885-ben sikertelenül kereste a növényt Csucsán és Kőrösfeketetónál a Sebes-Körös mentén, viszont megtálta a növényt a Bihar-hegységben a SebesKőrösbe torkolló Jád-patak felső folyásán, Remecztől (Jádremetétől) délre egy órányira, egészen pontosan a Lunka kotunin (Flatt szerint magyar nevén a Katona-völgyön). Ugyanakkor megtudta, hogy egy, a Jádba északról érkező völgyben, a Valea Kaluluj (Lovak-völgyén) is tenyészik a növény, és hogy a Jádon még délebbre, a belényesi uradalomhoz tartozó erdőkben is találtak $S$. josikaea-t. Flatt (1887) két új lelőhelyet talált a Jád mentén 1886-ban: egyet a remeczi Sipotyevölgyben a „Pareu-Freguczár” körül, egyet pedig a belényesi erdőben, a „Piatra Bulz” alatt.

Ezévben jelenik meg Simonkai erdélyi flóramüve is (1886). Ez amellett, hogy a korábbról ismertté vált néhány $S$. josikaea állomány összefoglalását adja, először ad említést a $S$. josikaea előfordulásáról az Aranyos-völgyből: „bőven a Bihar-hegységben az Aranyos mentén Albáktól 
Felső-szkerisoráig, vagyis Felső-Girdáig”. Simonkai már korábban ismerte ezt az állományt: „Albák és Szkerisora között” gyüjtött herbáriumi példánya van már 1880-ból is.

1886-ban találja meg a növényt Csató János (1886) is az Aranyos-völgyben Albaknál, a „Táczá Álbákuluj dupe Teur la doszu bészerícsí” nevü helyen a folyó jobb partján, de Albáktól feljebb már nem találta a növényt.

Bielz (1886) ebben az évben erdélyi vad orgonákat bemutató írásában - Simonkai és Csató mellett harmadikként - új előfordulásként közli az aranyos-völgyi élőhelyet, Wolff Gyula 1884-es „,bei Albák und Skerisóra” felfedezéseként. Fuss (1866) már említett székelykői adatának kétségbe vonása mellett pontosítja Baumgarten Mantissa-jának (Fuss 1846) Sebes-völgyi adatához tartozó „Henz” helyleírást, ami szerinte a Székelyótól észak-nyugatra húzódó Benczi-hegy vonulatára vonatkozhat.

1887-ben Michalus Sándor erdőmérnök a Bihar-hegység egy új vízgyűjtőjén, a FeketeKöröshöz tartozó Galbena-patak mentének két pontján, a Bulz és a Galbena összefolyásánál illetve az Aleo és Rumnyásza völgyében találta meg a fajt.

\subsubsection{0-1908: áttekintő tanulmányok az addig megismert elterjedésről}

1887-től két évtizeden keresztül több közlemény is napvilágot látott S. josikaea-ról, melyeknek nem témája újonnan talált állományok bemutatása, céljuk a $S$. josikaea faji önállóságának tisztázása, és az addig összegyült ismeretek széleskörü megismertetése. Mégis érdemes áttekinteni ezeknek az írásoknak a $S$. josikaea elterjedésére vonatkozó részeit, mivel a későbbiekben számos esetben hivatkoztak rájuk.

Simonkai (1890) Nagyvárad környékének flóráját bemutató művében részletesebben is foglalkozik a S. josikaea-val. Összefoglalja Bihar megyei előfordulásait: a Sebes-Körös mentéröl és a hozzá kapcsolódó Jád-völgyből, a Fekete-Körös mentéről, Aranyos-völgyből említi. A S. josikaea faji önállóságát morfológiai jellemzői alapján bizonyítja, és megállapítja, hogy nem valószínü, hogy ember által kerülhetett és maradt fenn ,,a leglakatlanabb s a legvadabb sziklás völgyek oly helyein, a melyekhez ember csak nagy üggyel-bajjal tud hozzáférkőzni”.

Flatt Károly 1891-ben jelentet meg egy tudományos-ismeretterjesztő összefoglaló mủvet a fajról, melyben a következő lelöhelyeket sorolja fel: Sebes, Csucsk (Csucsa elnyomtatva), Kelecsény, Feketetó, Aranyos-forrás, Albák vidéke, Remecz: Lunka kotuni, Pareu Freguczár, Piatra Bulzi, Belényes, Kis-Pásztély, Lyutta-völgy.

A faj bekerült Fekete Lajos és Mágocsy-Dietz Sándor (1896) Erdészeti növénytan címü könyvébe, az ebben szereplő hiányos elterjedési adatokat (Fekete-Körös-völgye) javítja Michalus fentebb említett 1887-es adataival (1898). 
Gulyás Antal (1907 és ugyanerre a munkára vonatkozóan 1906, 1910) igen aprólékos munkája kitér a S. josikaea történetére, virágzásbiológiájára, gyógyhatású anyagaira, népies neveire, szervezettani és morfológiai jellemzőire, összehasonlítást tesz a rokon Syringa fajokkal. A faj elterjedését taglaló részhez a következő adatokat írja: a Flatt $(1886,1887)$ által megtalált Jád-völgyi populációk közül „Lunka Kotuni környékén, a Sipotye-völgyben a Pareu Freguczar körül, és északabbra a Valea Kaluluj környékén is igen sok példányt láttam” (5. ábra). Utóbbit Flatt elbeszélése alapján írta le, később nem közli megtalálását, és herbáriumában sincs nyoma. Itt tehát Gulyás is megerősíti, hogy valóban létezik egy állomány a Valea Kalulujban. Említi a Bulz és Galbena összefolyásánál, az Aleu és Rumnyásza összefolyásától északra, Csucsa környékéről, Feketetóról. Említi továbbá a $S$. josikaea-t a Nagysebes és Székelytó (sic!) közötti területről és Székelykőről minden bizonnyal Fuss (1866) alapján, illetve az Aranyos forrásvidékéről: „Vidra, Szkerisora és Albák közt”. Vidra sehol máshol nem szerepel az irodalomban, ezért elképzelhető, hogy az az aranyos-menti Girda elírása. Vidra nevü helység ugyan van a közelben, de nem Szkerisora és Albák között, hanem Campenitől (Tompánfalvától) nyugatra, a Kis-Aranyosvölgyében. Gulyás, bár nagyon aprólékos, több vizsgálatot is végzett, az elterjedési területtel kapcsolatban több ponton is pontatlanul fogalmazott.

\subsubsection{Az elterjedés további pontosítása Blattny Tibor nyomán 1909-től 1913-ig}

Mint láttuk, az 1890-es és 1900-as évek összefoglaló müveiben nem jelentek meg valódi új adatok a Syringa josikaea elterjedéséről. Az 1900-as évek elején aztán az 1880-as évek után egy újabb hullám jött el az $S$. josikaea elterjedésének megismerésében. Ez két kutató, Thaisz Lajos és Blattny Tibor nevéhez füződik, akik ekkor felváltva jelentkeztek új adatokat bemutató munkáikkal. Kettejük közül elsőként Thaisz (1909a) mutatta be eredményeit a nyilvánosságnak a növénytani szakosztály 1909. január 13-i ülésén, melyek még azévben írásosan megjelentek (Thaisz 1909b). Thaisz munkássága az Ukrajnai-Kárpátokra terjed ki elsősorban, amellyel megtöbbszörözte az addig ismert $S$. josikaea lelöhelyek számát. Az erdélyi állományoknál nem ír le új populációt csak összegzi a korábbi irodalmat egy-egy szóban: „Sebes”, „Csucsa”, „Aranyos forrás (Kolozsmegye)”, „Feketetó”, „Remecz - Lunka kotuni”, „Remecz - Pareu Freguczár”, „Belényes”, „az Aranyos mentén Albáknál s onnan Felső Szkerisoráig vagyis Felső-Girdáig”, „Meleg-Szamos községnél, valószínűleg a Meleg-Szamos mentén”. Ezek alapján valószínü, hogy Thaisz csak Flatt (1886) és Simonkai (1886) irodalmát olvasta, Flatt (1887) és Michalus (1887) adatait nem közli. Egyetlen újdonsága Erdélyre vonatkozóan az lehet, hogy látatlanban feltételezi, hogy a melegszamosi állomány a Meleg-Szamos partján van. 


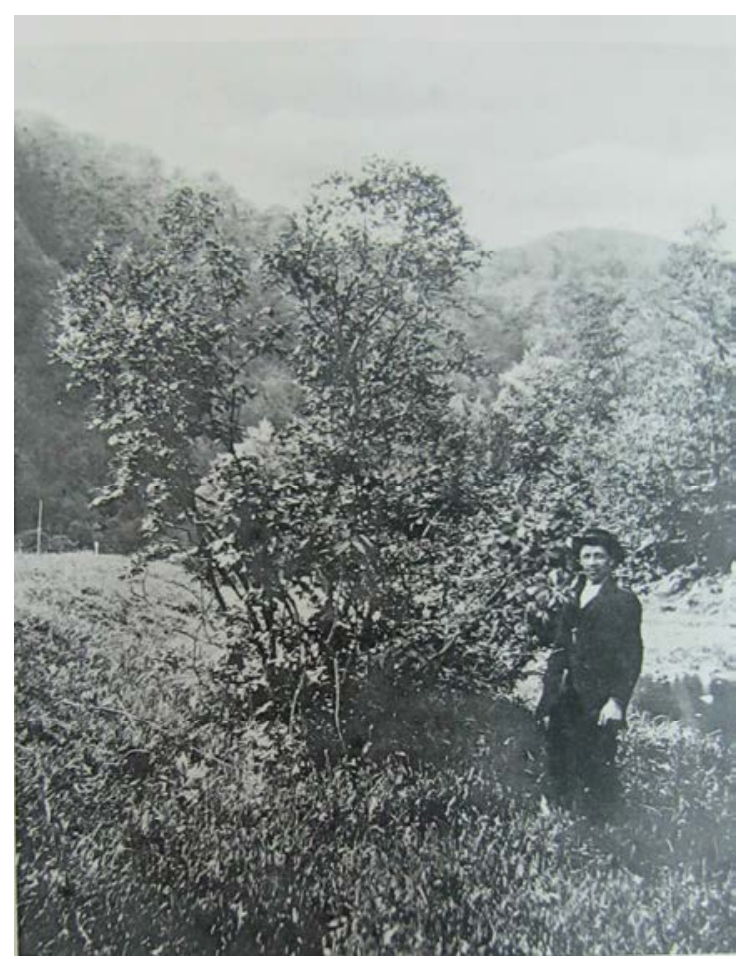

5. ábra: A Syringa josikaea egy példánya a mindmáig legjobban ismert a Jád-völgyi populációban. Archív felvétel, a kép eredetije Gulyás (1907) munkájában található.

Blattny Tibor 1906-tól került Fekete Lajos mellé, aki „Az erdészeti jelentőségű fák és cserjék elterjedése a magyar állam területén” (Fekete és Blattny 1913) címü flóramü elkészítésének gyakorlati feladatait Blattnyra bízta (Csapody 1970). A több éves adatgyüjtés során Blattny több, korábban ismeretlen populáció adatát gyüjti össze. 1910-ben jelenik meg az első S. josikaea-val foglalkozó rövid írása (Blattny 1910). Ebben megemlíti, hogy az Ung nyugati vízgyüjtőjén keresés ellenére sem került elő a $S$. josikaea. Egy új S. josikaea előfordulási adatot ír le: „A Biharhegységben legmagasabban fekvő termőhelye, Szkerisora határában, a „Riu albu” völgy (mésztalajon); 926 méternél”.

Blattny 1912-ben kutatási eredményei alapján Erdélyből egy új elöfordulást publikál: „Obersia-völgy a Gaina alatt”, melynek jelentősége, hogy ez a faj első Hunyad vármegyei, egyben legdélebbi előfordulása (6. ábra; Blattny 1912a). 


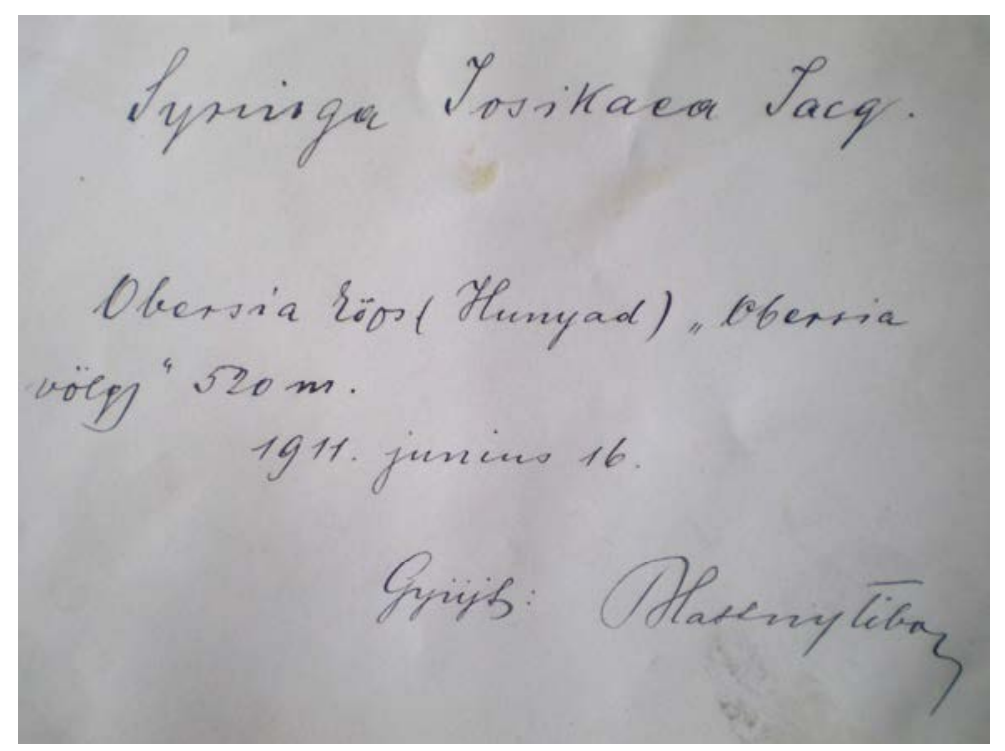

6. ábra: Blattny Tibor által herbáriumba gyüjtött, Obersia község mellől származó Syringa josikaea példány etikettje. A $S$. josikaea nagy valószínüséggel megsemmisült legdélebbi populációjából mára ez az egyetlen herbáriumi példány maradt (cf. Fekete és Blattny 1913). (Magyar

Természettudományi Múzeum Növénytárának herbáriuma [BP], No. 132073, saját felvétel)

Blattny az adatgyüjtése során előkerült előfordulásokat a Királyi Magyar Természettudományi Társulat Növénytani Szakosztályának 1912. december 11-i ülésén mutatta be részletesen (Blattny 1912b). Blattny és Thaisz együttmüködésére lehet bizonyíték, hogy Blattny dolgozatát Thaisz terjesztette elő. Az előadás írásos változata a következő évben jelent meg (Blattny 1913). Ebben javítja Thaisz (1909b) munkáját, és újabb populációkat közöl, de nem tér ki az összes előfordulás részletezésére. Erre majd csak az elkészült flóramüben kerít sort, amelynek szó szerinti alapjai Thaisz (1909b) változatlan formában átvett munkája valamint ezek javításai és kiegészítései (Blattny 1913).

\subsubsection{Fekete Lajos és Blattny Tibor - a korábbról ismert elterjedési adatok és az újabb kutatási eredmények szintézise, 1913}

Fekete és Blattny (1913, német kiadása 1914) alapvető müve összefoglalja és ismerteti a faj elterjedését, valamennyi populációt, amely a Magyar Királyság területére esik. Az Erdélyiszigethegység populációinál Thaisz (1909b) adatait pontosítják és jelentősen kiegészítik. Az első adat: „Nagysebes (Janka 1854). Nagysebes és Székelyó közt”. Fentebb tárgyaltuk, hogy Nagysebes minden bizonnyal Sebesvár település nevének félreírása. Megjegyzendő, hogy Janka csupán Nagysebest említett, az itt leírthoz leginkább Fuss (1846) leírása hasonlít. A második: „Csucsai völgy (Jósika bárónő)”, meglehetősen pontatlan, különösen annak fényében, hogy Jósika báróné adata is a Sebes-völgyböl származott (Gombocz 1935; Reichenbach 1830-1832). Nem szerepel viszont itt idézetként Simonkai csucsai adata, holott a szerzők ismerték Simonkai (1881) munkáját, hiszen a harmadik adat: „Kőrösfeketetó mellett (Simonkai 1880)”. A negyedik: „Remetelórév 
határában, a Lunka Kotuni környékén, állítólag ennek Valea Kaluluj nevü mellékvölgyében, körülbelül 4 km-re délre (Flatt K. 1885)" Ez alapján az olvasó Flatt (1886) ismerete nélkül egynek hiheti az ott két, külön név alatt szereplő közeli állományt. A negyedik és ötödik: „Remetelórév határában: Sipotye völgy a Magashegy lábánál, az úgynevezett Pareu Fregucár körül, igen sok (Flatt K. 1886)”. „Remetelórév határában, a Piatra Bulz sziklái alatt a Jád völgyön (Flatt K. 1886)”. Ezek pontos összefoglalásai Flatt (1887) adatainak. A hatodik, és utolsó állomány a Sebes-Körös leírása: „A Jád völgy felső szakaszán $3 \mathrm{~km}$ hosszban a katonai térkép 660m és 780 magassági pontjai közt. Michalus Sándor főerdőmérnök.” Blattny (1913) szerint ez korábban nem közölt adat, és a Flatt (1886) illetve őt követve Thaisz (1909b) belényesi adatának pontosítása lehet. Nem kizárt viszont az átfedés Flatt (1886) „Lunka Kotuni” adatával.

A Fekete-Kőrös vízgyűjtőjéből pontosítva szerepel Michalus (1887) két adata és egy új. Michalus adatai: „A Valea lu cale völgynek 620m, a katonai térkép 609m-nál betorkolló Rumnyásza nevü völgyében, jobb part. Michalus Sándor 1887.” „Vaskőfalva (Petrósz) határában a Galbina völgy balpartján (440m) a katonai térkép 435m-je közelében (Michalus Sándor 1887).” Az új adat pedig: „Biharmező (Pojána) határában, az Izvorul Giharulujnak „Vealea Csiresul” nevű mellékvölgyében a községtől 1 1 $1 / 2$ órányira $(658 \mathrm{~m})$ Felfedezte Katona László m. kir. Erdőmérnök 1901-ben."

A Fehér-Kőrös vízgyüjtőjéről egy korábban csak megemlített (Blattny 1912a) állomány leírása történik meg: „Obersia község határában, az Obersia völgy jobb partján, közvetlenül a patakparton $(520 \mathrm{~m})$ igen kevés számú példány. Michalus Sándor brádi föerdőmérnök felfedezése 1902.” Blattny (1913) még annyit tesz hozzá, hogy „,igen kevés példánya nő itt és félö, hogy a bükkösök folyamatban levő letarolásakor végleg kipusztul”.

Az Aranyos vízgyüjtőjén levő állományok (Blattny 1913): „A Nagyaranyos völgyén Fehérvölgy (Albák) körül. (Csató 1886)”. „A Nagyaranyos völgyén nemcsak Fehérvölgytől Aranyosfőig (Szkerisóráig), mely helyi elnevezés a nagy területen szétszórt házcsoportok miatt igen tág helymeghatározó - de a katonai térképen Lepus-nak jelölt házcsoport (templom 859m) alatt a völgy 849m magasan fekvő pontján is, csillámpalahordalékon (Simonkai 1885. évi felfedezése, Katona László-éval 1900. kiegészítve)”. „A Nagyaranyos baloldali mellékvölgyét képező - Lepus felett 2 km-re ezzel egyesülő - Riu albu patakon 926 m magasságig szórványosan, mészkőzeten. Katona László felfedezése 1900.” A két előbbi leírás elég pontatlan és átfedhet, valószínüleg hosszan elszórt orogna csoportokról van szó ezek esetében, Lepus és Albák között a távolság kb. 20 $\mathrm{km}$.

A Szamos vízgyüjtőjén szintén Blattny (1913) pontosítja az addig csupán egyszavas elterjedési adatot: „A Melegszamos mentén, a hasonnevű község alatt és környékén nem fordúl elő. 
A községtől fölfelé haladva, a folyó jobb oldali, Pareu Izvorluj nevü mellékpatakának torkolatától (alsó határ 470m) gyakori egész Jósikafalváig (Béles) 934m.” „A béles völgyén Jósikafalvától a Pareu Móri torkolatáig (felső határ 955m). Katona László bejelentése 1912.” Tehát Blattny egy hosszú völgy mentén két elkülönült foltról ír.

Thaisz (1909b, 1912), Blattny (1913) valamint Fekete és Blattny (1913) a Syringa josikaea összesen 34 önálló lelőhelyét gyüjtötte össze. Flatt az 1912. december 11-i növénytani szakosztályi ülés jegyzőkönyve szerint megjegyezte, hogy ő 35 termőhelyet ismer (Blattny 1912b). Amennyiben külön vesszük a helytelenül összevont remeczi Lunka Kotuni és Valea Kaluluj élőhelyeket, ez a szám ki is jön. Fekete és Blattny (1913) flóramüve a $S$. josikaea-nak nem csak addig ismert élőhelyeit gyüjtötte össze, de a kötetek adatgyüjtése során tisztázódott a meleg-szamosi élőhely pontos holléte, illetve a már korábbi években is ismert, de addig publikálatlan állományok leírására került sor (Obersia, Poiana, Riu albu). Főként a Sebes-Körös vízgyüjtőjén azonban maradt még munka: megerősíteni a csucsai, kőrösfeketetói populációk létét, pontosan meghatározni a Jád-völgyi populációk helyét. További pontatlanság, hogy míg Flatt (1886, 1887) és Blattny (1913) a Jádvölgyi populációkat Remeczhez (Jádremetéhez, ma: Remeți) rendeli, Fekete és Blattny (1913) már Remetelórévhez, amely pedig nem azonos Jádremetével.

\subsubsection{Az I. világháborútól napjainkig keletkezett szakirodalom}

A romániai irodalomban a fajra vonatkozóan kevés vizsgálati eredmény ismert. Alexandru Borza (1936) a S. josikaea-ról írt rövid közleményében csak nagy vonalakban említi az előfordulásokat (Meleg-Szamos, Aranyos, Kőrös völgyei, Jád-völgy; Stina de Vale). Lányával közösen írt Stina de Vale (Stâna de Vale, Biharfüred) flórája összeállításban is közli ezeket (Borza és Borza 1939). Soó Rezső (1944b) nem találja a fajt a Jád-völgyben, melyet bejárt a Jád SebesKőrösbe torkollásától a Jádremete feletti hegyekig, pedig járt a Sipotye-hegy lábánál is, ahol Flatt korábban felfedezte. Megtalálta viszont a Sebes-völgyben, Sebesvár és Székelyó között, ahol elötte már évtizedek óta nem keresték (1944a). A herbáriumi gyüjtések még közlemények hiányában is jelezhetik, hogy egy-egy populáció a botanikusok körében mennyire volt ismert. Biharfüredről több herbáriumi példányt is gyüjtöttek, ez annak is lehetett köszönhető, hogy a kolozsvári egyetem növénytani intézetének itt volt a kutatóállomása. Máshonnan viszont szinte nincs is herbáriumi példány. A két kivétel egyike Soó gyüjtése a Sebes-völgyből 1943-ból, a másik pedig Emil Pop gyüjtése a Galbena-völgyből, 1948-ból. Ez utóbbi ennek a populációnak egyetlen herbáriumi példánya.

A 20. század második feléből Resmeriţă (1970) a Vlegyásza-hegység flórájáról és vegetációjáról szóló monográfiájában Székelyóról említi, ahol, mint írja, kultúrában és ültetve is előfordul. Szükszavú leírásából nem derül ki a pontos lelőhely, és esetleg, hogy a vadon élő 
példányokat valóban látta-e, vagy csak az irodalomból ismert adatot közli. Értékes adatokat mutat be Stefan (1971), aki 1968-as megfigyelései alapján térképeken is bemutatja, hogy a Jád-völgyben és az Aleu - Valea cu Cale völgyekben hol talált orgonát, és az élöhelyeket védelemre érdemesnek tartja. Coldea (1972) a Réz-hegység vegetáció vizsgálatának fajlistájában Simonkaira hivatkozva említi Csucsán és Kőrösfeketetón. Raţiu et al. (1984) a Jád-völgy cönológiai vizsgálatát készítik el, és a szép $S$. josikaea állomány védelmének szükségességét hangsúlyozzák. Ardelean (1999) a Fehér-Kőrös vízgyüjtőjének flórájában Obarsia-hoz említi.

A nagyon kisszámú, orgonával érdemben foglalkozó dolgozat mellett érdekes, hogy a flóramüvekben, természetvédelmi kiadványokban hogyan alakultak az $S$. josikaea elterjedési adatai, hiszen alapvetően ezek szolgálják az alapot bármilyen természetvédelmi kezelés tervéhez. Prodan (1939) Román Flórája csak néhány helyet említ (Jád-völgyön felfele Stâna de Vale-ig, MelegSzamos-völgy, Aranyos-völgy, Körös).

A Román Flórában Morariu (1961) több olyan előfordulást közöl, amelyek a román nyelvü irodalomban előtte nem tűntek fel. A korábbi magyar irodalmakban, elsősorban Fekete és Blattny (1913) munkájában viszont megtaláljuk ezeknek az adatoknak a forrását is. A következő helyekről említik: Valea Drăganului, intre Valea Drăganului și Sâcueu; Ciucea pe V. Ciucea; Negreni; V. Belișului (din V. Someșului cald, intre 470-935m alt.); Gura Albacului pe V. Arieșului Mare, V. Arieșului Mare intre Gura Albacului și Gîrda de sus și la punctul Lâpus (r. Cîmpeni); Obîrșia pe malul drept al Pir. Obîrșia, 520 m alt.; Lorâu; la S de Remeți, V. Iadului sub Piatra Bulzului și în partea superiorâ a vâii între 660 si 780m alt.; Mții Bihorului în V. cu Cale din bazinului vâii Aleului, Pietrasa pe malul stîng al V. Galbena la $440 \mathrm{~m}$ alt., Poiana în V. Cireșului din V. Izvorul Bihorului.

Két újabb flóramü, Beldie (1979) és Ciocarlan (2009) ehhez képest kevésbé részletes. Két közelmúltbeli természetvédelmi mű hasonlóan pontos, mint Morariu (1961). Goriup (2008) munkája nem említi viszont Obîrșia-t, Lorâut illetve Lâpust. Dihoru és Negrean (2009) Morariu (1961) adatai mellett megemlíti még Raul alba-t és Stâna de Vale-t is.

\subsubsection{A munkám kezdetéig elfogadott Syringa josikaea elterjedési adatok az Erdélyi- szigethegységben}

Morariu (1961) adatai, szinte szó szerint átvéve Goriup (2008) valamint Dihoru és Negrean (2009) müveibe adják a $S$. josikaea erdélyi elterjedésének legújabb, legpontosabb, és minden bizonnyal természetvédelmi szempontból legjelentősebb gyüjteményét. Ezért fontosnak tartom az összes korábbi tanulmány áttekintése után e három mű elterjedési adatainak a revízióját. E művek a S. josikaea következő tíz állományát ismeretik az Erdélyi-szigethegységből (7. ábra). 
1. „Valea Drăganului, intre Valea Drăganului și Sâcueu”. Ennek az elterjedési adatnak szó szerinti előzménye Fekete és Blattny (1913) nagysebesi-székelyói adata. Viszont román fordításában megtévesztő, mivel Nagysebes román neve, Valea Drăganului azonos a falun is áthúzódó több tíz kilométeres völgy nevével (magyarul: Dregán-völgy vagy Nagy-Sebes-völgy). Emiatt joggal lenne hihető, hogy az adat erre a völgyre vonatkozik. Korábbról innen adat nem származott, sőt láttuk, hogy a nagysebesi adatok is valójában a Dregan-völgy helyett a Sebesvölgyre vonatkozhattak. Egyébként nem lenne elképzelhetetlen a S. josikaea felbukkanása a Dregan-völgyből, hiszen a vele párhuzamosan futó északi Jád-völgyben és délebbi Sebes-völgyböl is voltak előfordulási adatok. Ezt a Székelyó-Nagysebes előfordulást Dihoru és Negrean (2009) külön két előfordulásként írta le: az egyik „Sâcuieu (Henţii)”, ami, a Mantissa (Fuss 1846) „Henz” leírásának románosított változata lehet, némely térképen pedig a Sebes-völgyet evvel a névvel jelölik. Ez az adat csak átvétel, szerzői nem ismerték a $S$. josikaea előfordulását a Sebes-völgyböl (Gavril Negrean, szóbeli közlés). A másik előfordulás „Valea Drăganului”: amely alapján első pillantásra a település helyett sokkal inkább az azonos nevü völgyre lehetne gondolni. A sebesvárszékelyói előfordulási adatot személyes megfigyelés alapján utoljára Soó (1944a) erősítette meg.

2. „Ciucea pe V. Ciucea”: a csucsai-völgy, mint előfordulás már Fuss flórájában (1866) megjelenik, személyesen látta Simonkai (1881), aki viszont nem ad egészen pontos leírást a helyszínről és azóta nem találta senki.

3. „Negreni”: (Kőrösfeketetó), amit szintén Simonkai (1881) leírásából ismerünk, ezt is csupán a helyi lakosok elmondása alapján, azóta sem erősítette meg senki a létezését.

4. „V. Belișului (din V. Someșului cald, intre 470-935m alt.)”: a Meleg-Szamos völgye, amit Landoz (1844) óta ismerünk, ez a leírás pedig Blattny közleményében szerepel (1913). Morariu (1961) már csak Jósikafalva (Beliș) magasságáig említi, az 1960-1970-es években épült Bélesi-víztározó e fölött elpusztította $S$. josikaea patak menti élőhelyeit. Mégis Dihoru és Negrean (2009) így említi: ,pe Valea Belișului pânâ la confluența cu pârâu Morii, 955m”. Azaz Fekete és Blattny-hoz (1913) hasonlóan a Pareu Mori beömléséig ír S. josikaea előfordulást, annak ellenére, hogy a mára elöntött egykori falu magassága (934-935 m) és a Pareu Morii befolyása (955 m) közötti több kilométeres szakasz állandó víz alatt áll. Az elterjedési terület alsó határa, amelyet a Román Flórában még említenek, szintén pontatlanná vált, hiszen a 470 m-es magasságtól jóval magasabban is duzzasztók sora épült a Meleg-Szamoson, amelyek miatt ez a vonal feljebb csúszhatott.

5. „Gura Albacului pe V. Arieșului Mare, V. Arieșului Mare intre Gura Albacului și Gîrda de Sus și la punctul Lâpus (r. Cîmpeni)": az 1886-os művek (Bielz 1886, Csató 1886, Simonkai 1886) óta ismert a S. josikaea az Aranyos-völgyből. Dihoru és Negrean (2009) a Raul Alba 
kiegészítéssel pontosan visszaadják az innen ismert elterjedési területet (Fekete és Blattny 1913). Gulyás (1906) óta viszont nem ismert ezeknek az állományoknak a sorsa.

6. „Obîrșia, pe malul drept al Pir. Obîrșia, 520 m alt.”: Blattny (1910) említi elöször, és az egyetlen herbáriumi példánya is innen származik. Blattny (1913) szerint ez egy kis egyedszámú, veszélyeztetett állomány, melyet azóta nem látott senki.

7. „Lorâu” (Remetelórév): A Jád-völgyi jádremetei adatokat (Flatt 1886, 1887) Fekete és Blattny (1913) hibásan Remetelórévhez jelezték. Valószínű, hogy a ennek a hibás adatnak az átvétele és fordítása. Jádremete és Remetelórév közelsége mellett akár az is a félreértést erősíthette, hogy „Valea Kaluluj”, a $S$. josikaea egyik jádremetei előfordulási helyével azonos nevü völgy van Lorâu közelében is.

8. „la S de Remeți, V. Iadului sub Piatra Bulzului și în partea superioară a văii între 660 si 780m alt.”: Flatt (1886, 1887) és Michalus Sándor (Blattny 1913) Jád-völgyi adatait csupán olyan részletességgel közlik, mint Fekete és Blattny (1913), így az eredeti lelőhelyek közül Lunka Kotuni, Valea Kaluluj, Sipotele említése kimarad. Dihoru és Negrean (2009) csak Remeți és Stâna de Vale környékét említi, utóbbi települést Borza és Borza (1939) adata alapján. Stefan (1971) leírása és térképe jól bemutatja, hogy a Jád-völgy állománya elszórt kisebb foltokból, de nem nagyobb elkülönülő részekből álló populáció. Azóta is ez a leginkább számon tartott és ismert erdélyi $S$. josikaea állomány.

9. „Munții Bihorului în V. cu Cale din bazinului vâii Aleului, Pietroasa pe malul stîng al V. Galbena la 440 m alt.”: ezek a Michalus (1887) leírásából származó Valea cu Cale és Galbena-völgyi populációk, előbbinek Stefan leírása (1971), utóbbinak Emil Pop 1948-as herbáriumi lapja az utolsó föllelhető dokumentációja.

10. „Poiana în V. Cireșului din V. Izvorul Bihorului” (Biharmező): Blattny (1913) közli először, mint 1901-ben talált populációt. Azóta az állomány megtalálásáról írás vagy herbáriumi adat nem tanúskodik. Botanikusok szük köre azonban ismerte ezt az állományt (Pócs Tamás szóbeli közlése).

A S. josikaea román nyelven megjelent elterjedési adataiból látszik, hogy a legtöbb ezek közül még a korábbi magyar megfigyelésekből származik, azoknak átvétele. Bár léteznek egészen aktuális összefoglalások az $S$. josikaea elterjedéséről, azokban több adat is félreértéssel keletkezhetett, új állományok megtalálására nincsen bizonyíték. Gyakorlatilag mindegyik adat megerősítésre szorult, kiterjedtségükről, méretükről pedig semmilyen információ nem volt. 


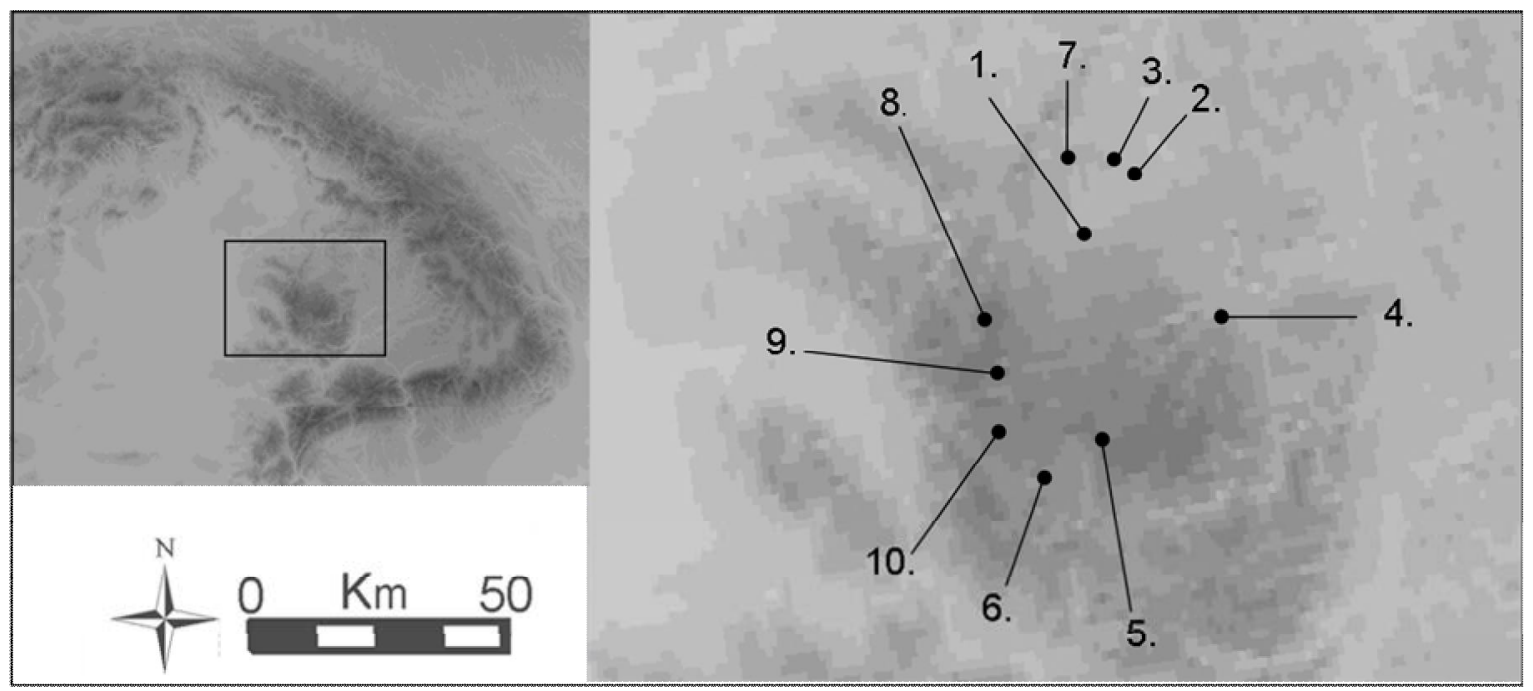

7. ábra: A Syringa josikaea elterjedése az Erdélyi-szigethegységben Morariu (1961), Goriup (2008) illetve Dihoru és Negrean (2009) alapján. A populációk leírását, csak úgy, mint az elterjedési adatok hiányosságait és hibáit lásd a szövegben.

\subsection{A Syringa josikaea elterjedési adatai az Ukrajnai-Kárpátokban}

Az Ukrajnai-Kárpátokban S. josikaea első populációit az Erdélyi-szigethegység állományaihoz képest később, az 1880-as években fedezték fel, majd az 1910-es évekre vált ismertté a mai elterjedés. Az ukrajnai populációk közül is több feledésbe merült az évtizedek alatt, az állományok felmérése az utóbbi években történt meg. Lendvay et al. (2012) 17 populáció létezését erősíti meg (4. táblázat, 8. ábra), Kohut (2013) ezek közül egy állomány két részét két külön populációnként említve 18-at tárgyal. Kohut és Höhn (2010) illetve Kohut (2013) az állományok élőhelyeit is részletesen elemzik, és megállapítják, hogy a S. josikaea állományok elsősorban patakokat kísérő lápos területeken fordulnak elő, amelyeken a faj példányai sok esetben összefüggő, klonális szaporodással kiterjedt állományokat alkotnak.

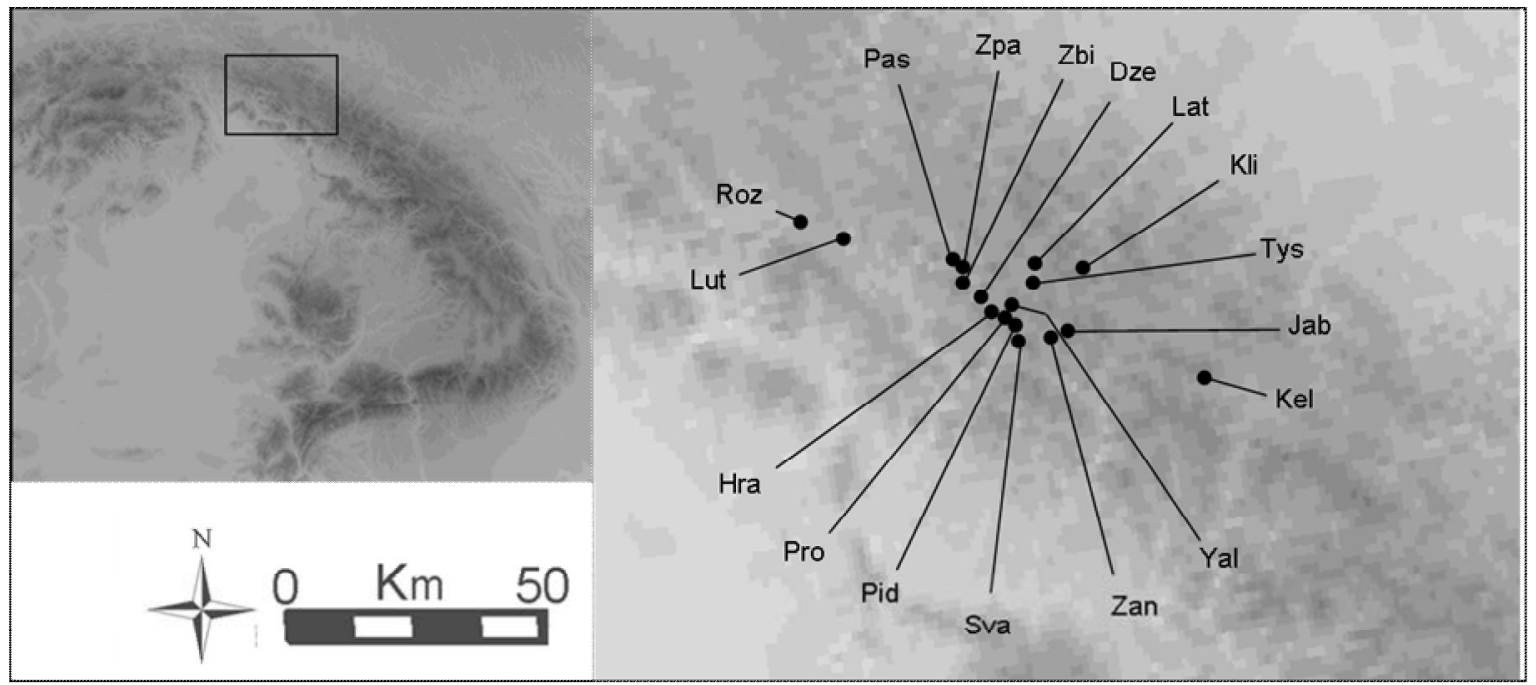

8. ábra: A Syringa josikaea populációi az Ukrajnai-Kárpátok területén. A populációk teljes nevét a 4. táblázat tartalmazza. 
4. táblázat: Syringa josikaea populációk az Ukrajnai-Kárpátokban. Az adatok Kohut és Höhn (2010), Lendvay et al. (2012) és Kohut (2013) munkáiból származnak.

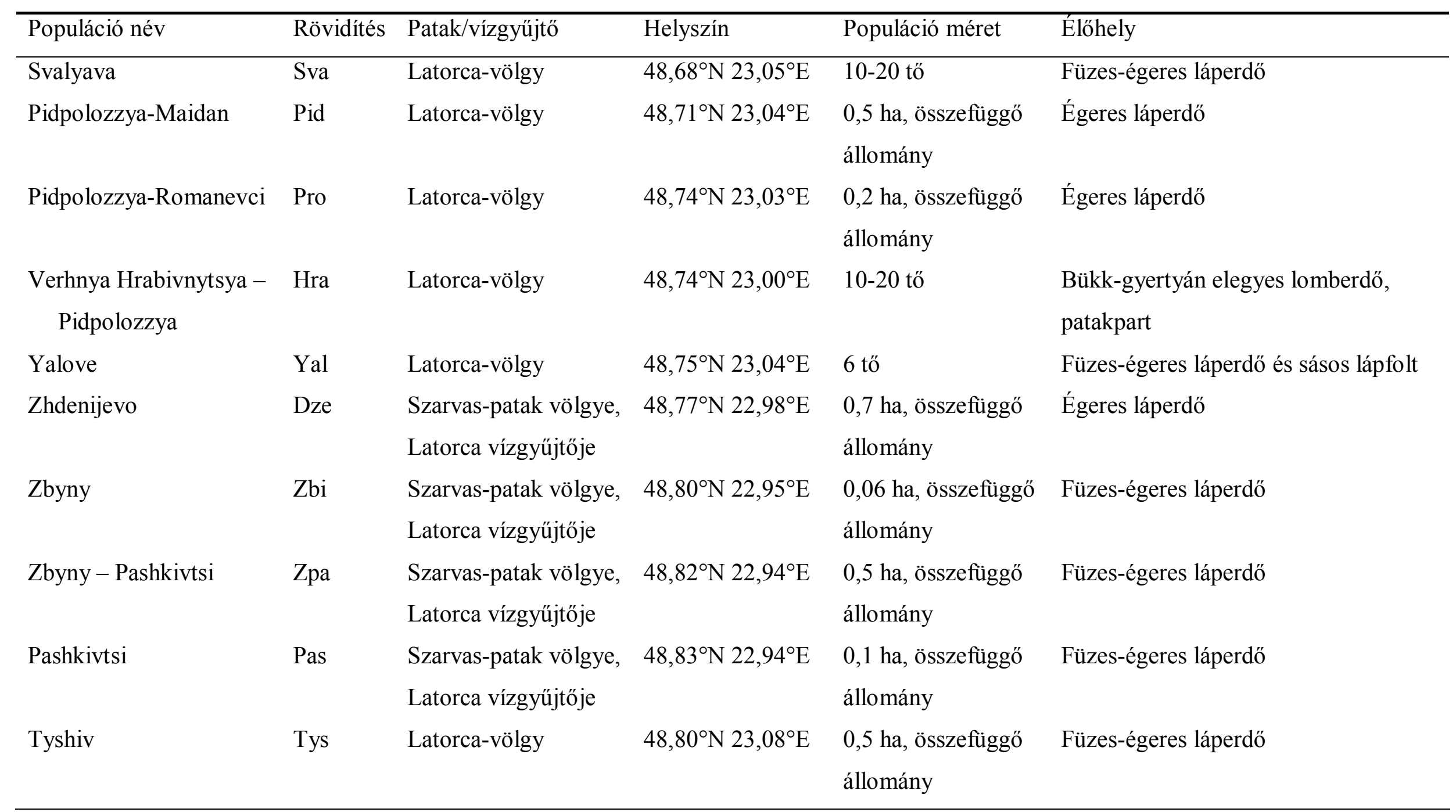


4. táblázat (folytatás): Syringa josikaea populációk az Ukrajnai-Kárpátokban. Az adatok Kohut és Höhn (2010), munkáiból származnak.

\begin{tabular}{|c|c|c|c|c|c|}
\hline Populáció név & rövidítés & patak/vízgyüjtő & Helyszín & populáció méret & élőhel \\
\hline Latorka & Lat & Latorca-völgy & $48,84^{\circ} \mathrm{N} 23,08^{\circ} \mathrm{E}$ & 3 tö & Patak \\
\hline Klimets' & Kli & Sztrij-völgy & $48,82^{\circ} \mathrm{N} 23,17^{\circ} \mathrm{E}$ & $\begin{array}{l}\text { 1,7 ha, összefüggő } \\
\text { állomány }\end{array}$ & Égere \\
\hline Jablonyevo & $\mathrm{Jab}$ & $\begin{array}{l}\text { Vicsa-völgy, } \\
\text { Latorca vízgyüjtője }\end{array}$ & $48,71^{\circ} \mathrm{N} 23,14^{\circ} \mathrm{E}$ & $\begin{array}{l}1 \text { ha, összefüggő } \\
\text { állomány }\end{array}$ & Legel \\
\hline Zanyka & Zan & $\begin{array}{l}\text { Vicsa-völgy, } \\
\text { Latorca vízgyüjtője }\end{array}$ & $48,68^{\circ} \mathrm{N} 23,11^{\circ} \mathrm{E}$ & 20-30 tö & Égere \\
\hline Lyuta & Lut & $\begin{array}{l}\text { Lyuta-patak, } \\
\text { Ung vízgyüjtője }\end{array}$ & $48,88^{\circ} \mathrm{N} 22,69^{\circ} \mathrm{E}$ & $50-100$ tö & $\begin{array}{l}\text { Jegen } \\
\text { patak }\end{array}$ \\
\hline Kostryns'ka Roztoka & Roz & Ung vízgyüjtője & $48,92^{\circ} \mathrm{N} 22,61^{\circ} \mathrm{E}$ & $\begin{array}{l}0,5 \text { ha, összefüggő } \\
\text { állomány }\end{array}$ & Bükk \\
\hline Kelechyn & Kel & Nagyág-völgy & $48,61^{\circ} \mathrm{N} 23,41^{\circ} \mathrm{E}$ & $\begin{array}{l}\text { 0,15 ha, több } \\
\text { összefüggő } \\
\text { állomány }\end{array}$ & Égere \\
\hline
\end{tabular}




\section{Anyag és módszer}

\subsection{A Syringa josikaea Erdélyi-szigethegységi elterjedésének felmérése}

Felkerestem a $S$. josikaea összes irodalomban említett populációját az Erdélyiszigethegységben, felmértem az állományok méretét, állapotát, élőhelyét, és feljegyeztem a fajt veszélyeztető tényezőket. Összesen 13 patak vagy folyó szakaszon vizsgáltam végig a S. josikaea előfordulását.

Munkámhoz az irodalmi adatok áttekintésén túl áttanulmányoztam a budapesti Magyar Természettudományi Múzeum Növénytár (BP), a bukaresti Román Akadémia Biológiai Intézet (BUCA), a kolozsvári Babes-Bolyai Tudományegyetem Botanikus Kert (CL) herbáriumi példányait. A terepi kutatást 2009-2012 tenyészidőszakaszaiban végeztem.

A terepi munka során a természetvédelmi hivataloknál, erdészeteknél, majd esetenként a helyi lakosságnál is érdeklődtem a $S$. josikaea előfordulásairól. Az irodalomban jelzett helyeken (patakok, folyók mentén) végighaladva dokumentáltam a $S$. josikaea példányait. A megtalált példányok GPS pozícióját (összefüggő állomány esetében annak szélső pontjait) rögzítettem.

\subsection{Mintagyüjtés és DNS kivonás}

A genetikai vizsgálatokba bevontam a $S$. josikaea összes jelenleg ismert 25 állományát. A növényminták gyüjtését nagyrészt személyesen végeztem vagy részt vettem a mintagyüjtésben, kivéve a Roz (Ukrajna) illetve Sta és részben Cne (Románia) populációkat, ahol a mintákat Kohut Erzsébet doktorandusz társam illetve Höhn Mária témavezetőm gyüjtötte.

Mivel az egyes populációk mérete jelentősen eltér egymástól, ezért a populációnként mintázott egyedek száma is különböző, és függ a megtalálható egyedek számától. A legkisebb populációkból, ahol az egyedszám láthatóan nem haladta meg a tizet, az összes egyedről származik minta, a nagyobb populációkról pedig egy reprezentatív mintát gyüjtöttünk, törekedve a rétegzett mintavételre, azaz, hogy a populációk összes részét lefedje a minta. A populációk egyes részein belül pedig véletlenszerüen gyüjtöttünk mintát az egyedekről. Azokban a populációkban, elsősorban az Ukrajnai-Kárpátokban, ahol a populációk közel összefüggő állományokat alkotnak, sok esetben nehéz megállapítani az egyedhatárokat. Az ilyen populációkban igyekeztünk ránézésre különálló egyedekről gyüjteni mintát, lehetőség szerint egymástól legalább tíz méterre álló egyedekről. 
A mintázott egyedekről leveleket gyüjtöttünk, amelyeket rögtön szilika gél gyöngyök közé helyeztünk száradni, vagy nedves papírba csomagoltunk, és $-20{ }^{\circ} \mathrm{C}$-ra helyeztük további használatig. Az egyedek jelentős részéhez egyedi GPS pontokat is vettem fel. Amely példányok esetében nem került felvételre GPS pont, azoknak a hozzávetőleges pozícióját is meg lehetett utólag határozni a legközelebbi ismert pozíciójú egyedek helyzete alapján.

A DNS kivonást kb. 20 mg száraz vagy 80 mg nedves levél folyékony nitrogénben való szétdörzsölése után a Qiagen DNeasy Plant Mini Kit (Qiagen, Hilden, Németország) DNS-kivonó készlet felhasználásával a gyártó leírása alapján végeztem, az extrakciós puffer (AP1) mennyiségének $700 \mu$ l-re növelésével. A kivont DNS-ek koncentrációját Nanodrop ND-1000 (NanoDrop Technologies, Wilmington, DE, USA) spektrofotométeren ellenőriztem.

\subsection{Molekuláris módszerek}

\subsubsection{Fajon belül variábilis DNS szakaszok keresése}

A kloroplsztisz nem kódoló DNS szakaszait több mint húsz éve használják evolúciós kutatásokban, így az utóbbi évekre sok információ gyült össze különböző kloroplasztisz DNS szakaszok általános, relatív variabilitásáról. Ez alapján ismert, hogy mely kloroplasztisz lókuszokban várhatók mutációk fajon belül is. 16 kloroplasztisz szekvencia variabilitását teszteltem a $S$. josikaea különböző populációi között magasabbrendü növényekben univerzálisan alkalmazható primerek segítségével (Shaw et al. 2005, Shaw et al. 2007, 5. táblázat). Minden egyes régiót 4-8 mintán szekvenáltam meg, amely minták a $S$. josikaea elterjedési területének különbözö, távoli populációiból származtak (pl. Gal, Seb, Roz, Kel, Sva, Kli populációk). A 16 közül 13 DNS szakasznak a felszaporítása és szekvenálása volt sikeres (5. táblázat).

Alacsony kópiaszámú nukleáris gén intronok közül kettőnek az amplifikálhatóságát és szekvencia variabilitását teszteltem. Az egyik ilyen régió az Eif3E (eukarióta tranaszláció iniciációs faktor 3-as komplex E alkotóelemének génje) amely a konzervált ortológ gének közé (conserved ortholog genes, COS) származik. Ennek a génnek a konzervatív régióira tervezett primerek rendszertanilag szélesebb körben is amplifikálhatónak bizonyultak, és a régió nagy variabilitásának köszönhetően alacsony filogenetikai szinten akár fajon belül is megfelelően variábilisnak bizonyult (Li et al. 2008). A másik régió a nia-i3 (nitrát-reduktáz enzim génjének 3-as intronja), amelynek primerjeit az Olea europaea-ra tervezték, és a gén kellően variábilisnak bizonyult O. europaea fajták elkülönítésére és jellemzésére (Hamman-Khalifa 2007).

A riboszomális RNS-t kódoló gén három szakaszának szekvencia variabilitását teszteltem. A Li et al. (2001) által Syringa-knál sikeresen alkalmazott primer párral amplifikáltam a teljes ITS 
régiót (ITS1, 5,8S RNS kódoló szakasz, ITS2). Az ugyanezen szerzők által tervezett ETS primerekkel amplifikáltam az ETS régiónak a 18S RNS-t kódoló szakaszt határoló szakaszát. Ezt kiegészítettem az ETS régió egy további, az ETS előbb említett szakaszát határoló, tőle 5' (upstream) irányban levő szakaszával (ETS 5'). A második ETS régiót a Baldwin és Markos (1998) által ETS primerek tervezéséhez ajánlott módszer alapján amplifikáltam és szekvenáltam; a teljes riboszomális intergenic spacer szakaszt (IGS) felszaporítottam, és ennek egy szakaszát szekvenáltam meg egy szekvenáló primerrel, amelynek szekvenciája a Li et al. (2001) által tervezett ETS primer pár 5' irány felőli tagjának (STT-ETS) reverse complementje volt. Mivel a megszekvenált példányokban e szakasz szekvenciája nem volt variábilis, ezért a szakasz direkt amplifikációjához primereket nem terveztem. A riboszomális RNS-t kódoló DNS szakaszok és a primerek elhelyezkedését az F4. ábra szemlélteti.

A PCR reakciókat $20 \mu \mathrm{l}$ össztérfogatban készítettem, melyek a következő összetevőket tartalmazták: $1,2 \mathrm{mM} \mathrm{MgCl}{ }_{2}, 0,2 \mathrm{mM}$ dNTPs, $0,8 \mu \mathrm{M}$ forward és reverse primer, $10^{-2} \mathrm{mg} / \mathrm{ml} \mathrm{BSA}$, 0,8 u Taq DNS polimeráz (New England Biolabs, Frankfurt aM, Németország) és neki megfelelő $1 \times$ Taq reakció puffer és $1,5 \mu \mathrm{l}(\mathrm{kb} .20 \mathrm{ng})$ templát DNS. A PCR reakciók egy Biometra T (Biometra, Göttingen, Németország) készülékben futottak le. A PCR reakciók 1 perc kezdeti denaturációval indultak $94{ }^{\circ} \mathrm{C}$-on, ezt 35 darab $94{ }^{\circ} \mathrm{C}$-os 30 s-os dentaurációból, lókuszonként változó hőmérsékletű (lásd 5. táblázat) 30 s-os tapadási lépésből, $72{ }^{\circ} \mathrm{C}$-os 1 perces elongációs lépésből álló ciklus követte, végső elongációs lépéssel $72{ }^{\circ} \mathrm{C}$-on 8 percig. A PCR reakciók sikerességét 0,8\%-os etidium-bromid festésű agaróz gélen ellenőriztem, majd a PCR termékek tisztítási reakciójaként $16 \mu \mathrm{l}$ PCR termékhez 6,4 $\mu$ l exoSAP enzim-elegyet (USB, Cleveland, OH, USA) adtam, és alapos keverés után $37{ }^{\circ} \mathrm{C}$-on inkubáltam 15 percig, majd a reakciót $85{ }^{\circ} \mathrm{C}$-ra melegítve állítottam le. A szekvenálási reakciót ABI BigDye terminátor 3.1 (Applied Biosystems) rendszerrel végeztem a gyártó ajánlásainak megfelelően. A terméket tisztítottam Sephadex G-50 (GE Healthcare Europe, Solingen, Németország) multi-screen-HV platen (96-well filtration plate; Millipore Corporation, Billerica, MA, USA) és a szekvenálás egy ABI 3130x1 (Applied Biosystems) készüléken történt mindkét DNS-szálon. Egyes lókuszoknál az itt leírtaktól való eltéréseket az 5. táblázatban külön jeleztem. 
5. táblázat: A Syringa josikaea populációi közti szekvencia variabilitásra vizsgált DNS régiók amplifikációjához használt primerek jellemzői.

\begin{tabular}{|c|c|c|c|c|}
\hline$\overline{\text { Lókusz név }}$ & Primer név & $5^{\prime}-3^{\prime}$ primer szekvencia & Hivatkozás & $\mathrm{T}_{\mathrm{a}}\left({ }^{\circ} \mathrm{C}\right)$ \\
\hline \multicolumn{5}{|c|}{ Kloroplasztisz nem kódoló DNS szakasz } \\
\hline \multirow{2}{*}{ atpI-atpH } & F: atpI & TATTTACAAGYG GTATTCAAGCT & \multirow{2}{*}{ Shaw et al. 2007} & \multirow{2}{*}{$\varnothing$} \\
\hline & $\mathrm{R}: \operatorname{atpH}$ & CCAAYCCAGCAGCAATAAC & & \\
\hline \multirow{2}{*}{ ndhF-rpl32 } & F: ndhF & CСAATATCССТTYYTTTTCCAA & \multirow{2}{*}{ Shaw et al. 2007} & \multirow{2}{*}{52} \\
\hline & $\mathrm{R}: \operatorname{rlp} 32-\mathrm{R}$ & GAAAGGTATKATCCAYGMATATT & & \\
\hline \multirow{2}{*}{ psbA-trnH } & $\mathrm{F}: \mathrm{psbAF}$ & GTTATGCATGAACGTAATGCTC & \multirow{2}{*}{ Sang et al. 1997} & \multirow{2}{*}{$\varnothing$} \\
\hline & $\mathrm{R}: \operatorname{trnHR}$ & CGCGCATGGTGGATTCACAAATC & & \\
\hline \multirow{2}{*}{ psbD-trnT } & $\mathrm{F}: \mathrm{psbD}$ & CTCCGTARCCAGTCATCCATA & \multirow{2}{*}{ Shaw et al. 2007} & \multirow{2}{*}{54} \\
\hline & R: $\operatorname{trnT}(\mathrm{GUU})-\mathrm{R}$ & СССТTTTAACTCAGTGGTAG & & \\
\hline \multirow{2}{*}{ psbJ-petA } & $\mathrm{F}: \mathrm{psbJ}$ & ATAGGTACTGTARCYGGTATT & \multirow{2}{*}{ Shaw et al. 2007} & \multirow{2}{*}{54} \\
\hline & $\mathrm{R}: \operatorname{pet} \mathrm{A}$ & AACARTTYGARAAGGTTCAAT T & & \\
\hline \multirow{2}{*}{ rpl16 } & F: Rpl16F71 & GCTATGCTTAGTGTGTGACTCGTTG & \multirow{2}{*}{ Small et al. 1998} & \multirow{2}{*}{54} \\
\hline & R: Rp116R1516 & СССТTCATTCTT CCT CTA TGTTG & & \\
\hline \multirow{2}{*}{$\operatorname{rps} 16$} & $\mathrm{~F}: \mathrm{rpS} 16 \mathrm{~F}$ & AAACGATGTGGTARAAAGCAAC & \multirow{2}{*}{ Shaw et al. 2005} & \multirow{2}{*}{54} \\
\hline & $\mathrm{R}: \mathrm{rpS} 16 \mathrm{R}$ & AACATCWATTGCAASGATTCGATA & & \\
\hline \multirow{2}{*}{ trnC-rpoB } & $\mathrm{F}: \operatorname{trnC}{ }^{\mathrm{GCA}} \mathrm{R}$ & CACCCRGATTYGAACTGGGG & \multirow{2}{*}{ Shaw et al. 2005} & \multirow{2}{*}{54} \\
\hline & $\mathrm{R}: \mathrm{rpoB}$ & CKACAAAAYCCYTCRAATTG & & \\
\hline
\end{tabular}


5. táblázat (folytatás): A Syringa josikaea populációi közti szekvencia variabilitásra vizsgált DNS régiól jellemzői.

\begin{tabular}{|c|c|c|c|}
\hline Lókusz név & Primer név & 5' $-3^{\prime}$ primer szekvencia & Hivatkozás \\
\hline \multicolumn{4}{|c|}{ Kloroplasztisz nem kódoló DNS szakasz } \\
\hline \multirow{2}{*}{$\operatorname{trnD}-\mathrm{psbM}$} & $\mathrm{F}: \operatorname{trn}^{\mathrm{GUC}} \mathrm{R}$ & GGGATTGTAGYTCAATTGGT & \multirow{2}{*}{ Shaw et al. } \\
\hline & $\mathrm{R}: \mathrm{psbMF}$ & AGCAATAAATGCRAGAATATTTACTTCCAT & \\
\hline \multirow{2}{*}{ 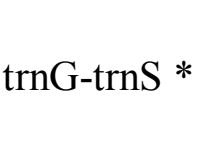 } & $\mathrm{F}: 3^{\prime} \operatorname{trnG} \mathrm{UUC}^{\mathrm{UC}}$ & GTAGCGGGAATCGAA CCC GCATC & \multirow{2}{*}{ Shaw et al. } \\
\hline & $\mathrm{R}: 5^{\prime} \operatorname{trn} \mathrm{S}^{\mathrm{GCU}}$ & AGATAGGGATTCGAACCCTCGGT & \\
\hline \multirow{2}{*}{ rps16-trnK } & $\mathrm{F}: \operatorname{rps} 16 \times 2 \mathrm{~F} 2$ & AAAGTGGGTTTTTATGATCC & \multirow{2}{*}{ Shaw et al. } \\
\hline & $\mathrm{R}: \operatorname{trnK}(\mathrm{UUU}) \times 1$ & TTAAAAGCCGAGTACTCTACC & \\
\hline \multirow{2}{*}{$\operatorname{trnL}$} & $\mathrm{F}: 3^{\prime} \operatorname{trnL} \mathrm{UAA}^{\mathrm{U}} \mathrm{R}(\mathrm{TabD})$ & GGGGATAGAGGGACTTGAAC & \multirow{2}{*}{ Taberlet et } \\
\hline & $\mathrm{R}: 5^{\prime} \operatorname{trnL}{ }^{\mathrm{UAA}} \mathrm{F}(\mathrm{TabC})$ & CGAAATCGGTAGACGCTACG & \\
\hline \multirow{2}{*}{ rpl32-trnL } & F: rpl32-F & CAGTTCCAAAAAAACGTACTTC & \multirow{2}{*}{ Shaw et al. } \\
\hline & $\mathrm{R}: \operatorname{trnL} \mathrm{L}^{(\mathrm{UAG})}$ & CTGCTTCCTAAGAGCAGCGT & \\
\hline \multirow{2}{*}{$\operatorname{trnQ-rps16}$} & F: trnQ(UUG) & GCGTGGCCAAGYGGTAAGGC & \multirow{2}{*}{ Shaw et al. } \\
\hline & $\mathrm{R}: \operatorname{rps} 16 \mathrm{x} 1$ & GTTGCTTTYTACCACATCGTTT & \\
\hline \multirow{2}{*}{$\operatorname{trnT}-\operatorname{trnL}$} & F: trnT ucp-a & CATTACAAATGCGATGCTCT & \multirow{2}{*}{ Taberlet et } \\
\hline & $\mathrm{R}: \operatorname{trnL}$ ucp-b & TCTACCGATTTCGCCATATC & \\
\hline \multirow{2}{*}{$\operatorname{trnT}-\operatorname{trn} \mathrm{D}$} & $\mathrm{F}: \operatorname{trn} \mathrm{T}^{\mathrm{GGU}}$ & CTACCACTGAGTTAAAAGGG & \multirow{2}{*}{ Demesure $\epsilon$} \\
\hline & $\mathrm{R}: \operatorname{trn}^{\mathrm{GUC}} \mathrm{F}$ & GGGATTGTAGTTCAATTGGT & \\
\hline
\end{tabular}


5. táblázat (folytatás): A Syringa josikaea populációi közti szekvencia variabilitásra vizsgált DNS régiók jellemzői.

\begin{tabular}{|c|c|c|c|}
\hline Lókusz név & Primer név & $5^{\prime}-3^{\prime}$ primer szekvencia & Hivatkozás \\
\hline \multicolumn{4}{|c|}{ Alacsony kópiaszámú nukleáris gén intron } \\
\hline \multirow{2}{*}{ Eif3E } & F: Eif3E-F & TTTGAATGTGGCAACTAYTCTRGTGCTGC & \multirow{2}{*}{ Li et al. 200} \\
\hline & R: Eif3E-R & АССТСТТСАСАСТСYҮТСАТСТТ & \\
\hline \multirow{2}{*}{ Nia-i3 ** } & F: Nia-i3-F & CGGAACCAGCARTTRTTCATCAT & \multirow{2}{*}{ Hamman-K } \\
\hline & R: Nia-i3-R & CAATTACTGGTGTTGGTGYTTYTGGTC & \\
\hline \multicolumn{4}{|c|}{ Nukleáris riboszomális gén nem kódoló DNS szakasz } \\
\hline \multirow{2}{*}{ ETS } & F: 18S-ETS & ACTTACACATGCATGGCTTAATCT & Baldwin és \\
\hline & R: STT-ETS & GGCWTGTKTGGGTATGTTGGAT & Li et al. 200 \\
\hline \multirow{2}{*}{$\operatorname{ETS} 5 * * *$} & F: 18S-ETS & ACTTACACATGCATGGCTTAATCT & \multirow{2}{*}{ Baldwin és } \\
\hline & R: 26S-IGS & GGATTGTTCACCCACCAATAGGGAACGTGAGCTG & \\
\hline \multirow{2}{*}{ ITS } & F: ITS-Leu & GTCCACTGAACCTTATCATTTAG & Baum et al. \\
\hline & R: ITS4 & TCCTTCCGCTTATTGATATGC & White et al. \\
\hline
\end{tabular}

Ta: optimális primer tapadási hőmérséklet

*: Shaw et al. 2005 alapján a két különböző hosszúságú PCR termék közül a nagyobb méretüt izoláltam gélb tisztítottam majd szekvenáltam

**: Hamman-Khalifa et al. (2007) alapján a két különböző hosszúságú PCR termék közül a nagyobb méretüt i után, és azt tisztítottam majd szekvenáltam

***: A PCR reakcióban az elongációs lépés 6 percig tartott, a szekvenálás csak egy irányban (5’ upstream, IGS 2001) oligonukleotid reverse complementerjének megfelelő szekvenciájú szekvenáló primerrel

Ø: a reakciót nem sikerült megfelelően optimalizálni tiszta szekvenciakromatogramok eléréséhez, Ta érték ninc 
A szekvenciákat a forward és reverse irányból a SEQUENCHER 4.8 (GENECODES, Ann Arbor, MI, USA) programban illesztettem össze, és a szekvenálási hibákat kijavítottam. Az azonos lókuszhoz tartozó mintákat ezután egymáshoz illesztettem, és a variábilis pozíciókat azonosítottam.

A tesztelt 21 lókuszból mindössze kettő, az ETS és az ITS bizonyult variábilisnak. Ezeket megszekvenáltam mind a 25 populáció összesen 62 egyedén. A nagyobb populációkból négy, a kisebbekből egy vagy két egyedet szekvenáltam meg (10. táblázat).

\subsubsection{Nukleáris mikroszatellit markerek tesztelése és fejlesztése}

\subsubsection{Olea és Ligustrum mikroszatellit markerek használhatósága a Syringa josikaea esetében}

A rokon fajokra tervezett markerekból összesen tizenkettőnek a hasznosíthatóságát teszteltem. Ezek közül kettő (Emo13, Emo90) származott a de la Rosa et al. (2002) által Olea europaea-ra tervezett mikroszatellit markerekből, melyeket e kutatók a $S$. vulgaris-ban is amplifikálhatónak és variábilisnak találtak, a további tíz marker a Kodama et al. (2008) által a Ligustrum ovalifolium-ra tervezett primer pár volt (Lig2, Lig8, Lig11, Lig14, Lig15, Lig18, Lig20, Lig21, Lig22, Lig101).

A S. josikaea DNS PCR amplifikálását mind a tizenkettő primer pár esetében először a leírásuknak megfelelö reakciókörülmények között kíséreltem meg, azokban az esetekben amikor ez nem járt sikerrel, megpróbálkoztam a PCR tapadási hőmérséklet $45^{\circ} \mathrm{C}$-ra való leszállításával, a $\mathrm{MgCl}_{2}$ koncentrációjának növelésével $4 \mathrm{mM}$-ig illetve különbözö DNS polimeráz enzimek használatával. Polimerázok közül próbálkoztam a recombinant Taq és DreamTaq (Thermo Scientific, Burlington, Kanada), valamint egy új-generációs polimeráz, a KAPAHiFi (Kapabiosystems, Boston, MA, USA) alkalmazásával.

Végül minden primer párt, amely sikeresen amplifikálta a $S$. josikaea DNS-ét, a következőkben leírt azonos körülmények között alkalmaztam. A PCR reakciókat az egyreakciós M13-tailed nested PCR technikával végeztem (Schuelke 2000), amelynek során a forward mikroszatellit primerek 5' vége egy M13(-21)F szekvenciájú oligonukleotiddal (5'GTAAAACGACGGCCAGT-3') van meghosszabbítva, és 5' 6-FAM fluoreszcens jelölésű M13(21)F oligonukleotidot adunk a reakció elegyhez harmadik primerként. Ezzel a módszerrel az összes tesztelendő primer pár egy-egy tagjának fluoreszcens jelölése helyett csupán egyetlen fluoreszcens jelölésű M13(-21)F primerre van szükségünk. Ez költségkímélő megoldást jelenthet ahhoz képest, mintha minden egyes tesztelendő primer párt fluoreszcens jelöléssel kell beszerezni, így ez a technika ideális markerek teszteléséhez. 
Minden egyes PCR reakcióelegy $20 \mu 1$ térfogatban készült $1 \times\left(\mathrm{NH}_{4}\right)_{2} \mathrm{SO}_{4}$-t tartalmazó Taq DNS polimeráz reakció pufferral (Thermo Scientific), 2,5 $\mathrm{mM} \mathrm{MgCl}_{2}, 0,2 \mathrm{mM}$ dNTPs, $0,25 \mu \mathrm{M} 5$, M13(-21)F meghosszabbítású forward primer, 0,75 $\mu \mathrm{M}$ reverse primer, 0,5 $\mu \mathrm{M}$ 5' 6-FAM fluoreszcens jelölésű M13(-21)F primer és 0,5 U recombinant Taq DNS polimeráz (Thermo Scientific) jelenlétében. A reakcióelegyhez kb. 15 ng templát DNS-t adtam. A PCR reakciók PTC 200 PCR (MJ Research, Waltham, MA, USA) készülékben készültek 5 perc kezdeti denaturációval indítva, melyet 30 ciklus $94{ }^{\circ} \mathrm{C}$-os denaturáció, $52{ }^{\circ} \mathrm{C}$-os tapadás és $72{ }^{\circ} \mathrm{C}$-os elongáció követett, minden egyes lépést 30 másodpercig tartva, végül egy utolsó elongációs lépés történt $72{ }^{\circ} \mathrm{C}$-on 30 percig. A hosszú végső elongációs időt a PCR fragmentumok hossz-dadogásának (lenght stuttering) lehetőség szerinti csökkentésére alkamaztam; a csupán két bázispáros ismétlődések esetében a nem teljes PCR termékek (amelyek akár csak egy bp hosszal rövidebbek, a PCR termék 3' végén hiányzó extra timin miatt) a kiértékelésnél zavart okozhatnak (Dewoody et al. 2006).

A sikeresen amplifikált lókuszok variabilitását és a markerek S. josikaea-ra való karakterizálását 20-20 DNS mintán végeztem, amelyek a S. josikaea elterjedésének két eltérő részéről származtak; a Pidpolozzya (Ukrajnai-Kárpátok) környéki erdőkből és Remeţi (Erdélyi-szigethegység) környékéről. A két mintát közeli populációk összevonásával hoztam létre, hogy méretük megfelelő nagyságú legyen populációgenetikai analízisek elvégezéséhez. A PCR fragmentumokat ABI 3100 (Applied Biosystems, Foster City, CA, USA) készülék kapilláris elektroforézis rendszerén kerültek elválasztásra, GenScan - 500 ROX belső méret standard (Applied Biosystems) használatával. A PCR fragmentumok pontos hosszát a GeneMapper szoftver (Applied Biosystems) 3.7-es verziójával értékeltem ki.

\subsubsection{De novo mikroszatellit marker fejlesztés}

Mikroszatellit markerek fejlesztésére több egészen különböző elven alapuló technika létezik. A figyelembe vehető megoldások közül egy olyan módszert alkalmaztam, amely viszonylag kis költségigényü és hatékony, nem utolsó sorban pedig a laboratóriumi lépések jelentős részéhez rendelkezésre állt felszerelés és tapasztalat a BCE Genetika és Növénynemesítés Tanszékének molekuláris laboratóriumában. A módszer fő lépéseinek összefoglalását az 9. ábra mutatja.

Egy mikroszatellit-dúsított könyvtár (microsatellite enriched library) létrehozásán alapuló módszert választottam, amelynek alapját két hasonló, sokat idézett megoldás, a Bloor et al. (2001) által leírt és a FIASCO protokoll (Zane et al. 2002) szolgáltatta. 

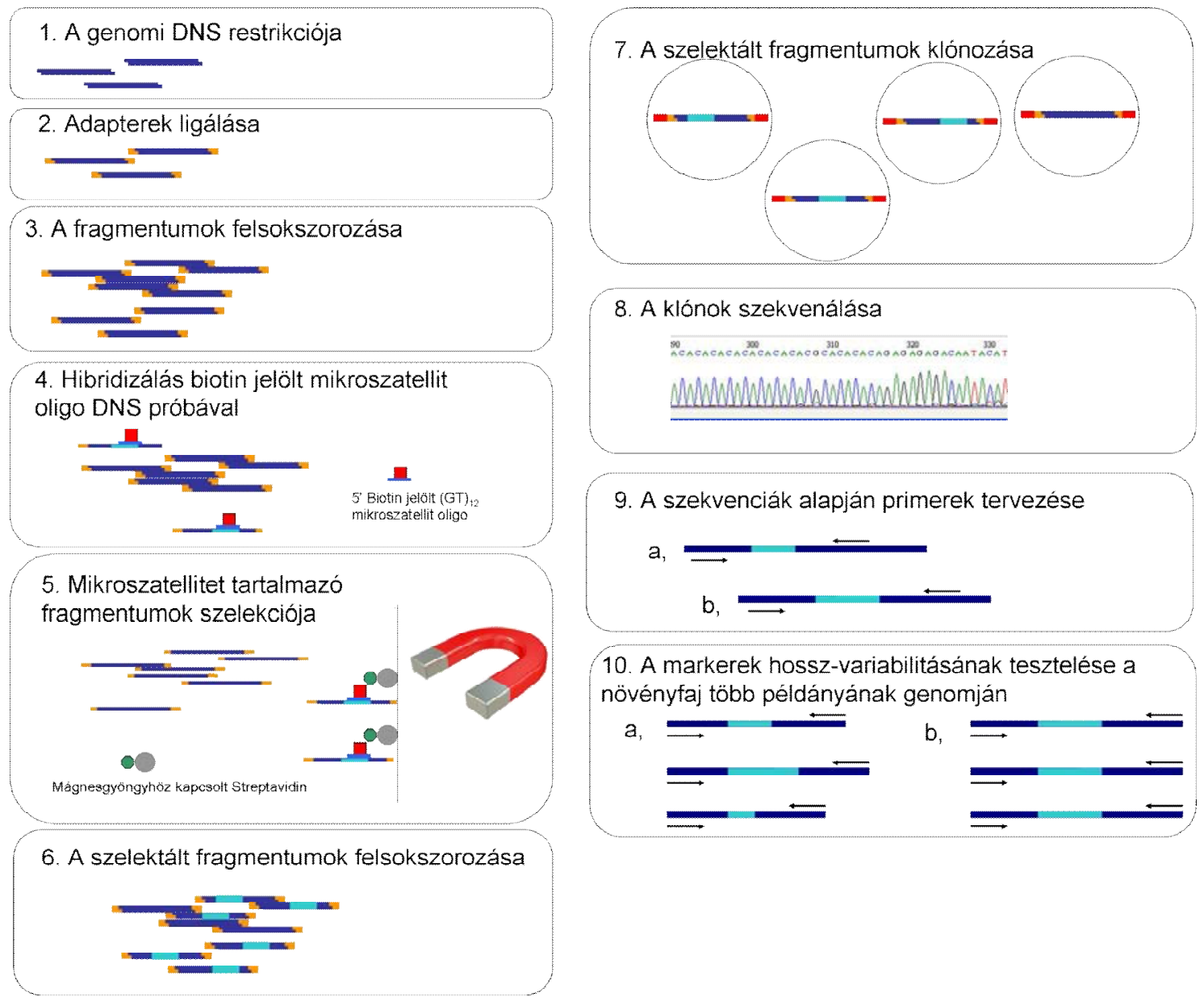

9. A szekvenciák alapján primerek tervezése

a,

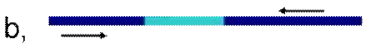

10. A markerek hossz-variabilitásának tesztelése a növényfaj több példányának genomján
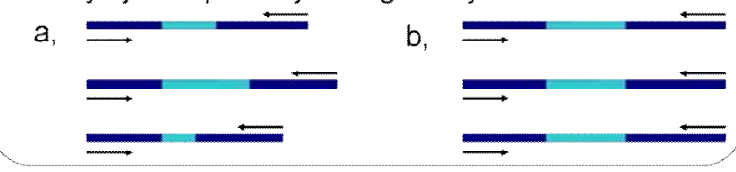

9. ábra: A mikroszatellit fejlesztés protokolljának sematikus rajza tíz lépésben (saját ábra; csak a főbb lépéseket mutatja be, a részleteket és magyarázatot lásd a szövegben).

A módszerhez kiindulásként nagy koncentrációjú fragmentálódás-mentes DNS-re van

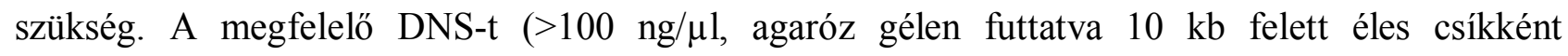
mutatkozik) a fentebb leírt módon friss rügy mintából izoláltam egy Jad populációból (Erdélyiszigethegység) származó példányból. A könyvtár létrehozásának első lépéseként a DNS-t teljesen emésztettem a négybázisos (TTAA) felismerőhelyü Tru1I restrikciós enzimmel (Thermo Scientific) a gyártó leírása alapján. A reakció leállítását kloroformos tisztítással végeztem: az enzim kloroformos kioldása után a DNS-t izopropanlollal kicsaptam és centrifugáltam, majd a kapott csapadékot $70 \%-20{ }^{\circ} \mathrm{C}$-os alkohollal mostam és szárítás után desztillált vízben feloldottam. A feldarabolt DNS szakaszokat hozzáligáltam egy megfelelő ragadós végű adaptorhoz „Top/Bottom” 5'-CTCGTAGACTGCGTACC-3'/3'-CATCTCTGACGCATGGATT-5' T4 DNS ligáz (Promega, Madison, WI, USA) alkalmazásával. Ezt követően PCR reakciót készítettem a „Top" oligonukleotidot használva primerként $20 \mu \mathrm{l}$ végtérfogatban $1 \times\left(\mathrm{NH}_{4}\right)_{2} \mathrm{SO}_{4}$-t tartalamazó Taq DNS polimeráz reakció puffer (Thermo Scientific), 1,2 $\mathrm{mM} \mathrm{MgCl}_{2}, 0,2 \mathrm{mM} \mathrm{dNTPs}, 25 \mu \mathrm{g} / \mathrm{ml} \mathrm{BSA,} \mathrm{1,6}$ $\mu \mathrm{M}$ “Top” primer, 0,5 U recombinant Taq DNS polimeráz (Thermo Scientific) és 1,5 $\mu$ ligált DNS templátként. A PCR reakció 5 perc $94{ }^{\circ} \mathrm{C}$ denaturációval kezdődött, melyet 30 darab $30 \mathrm{~s} 94{ }^{\circ} \mathrm{C}$-os 
denaturációból, 30 s-os $52{ }^{\circ} \mathrm{C}$-os primer-kötésből és 1 perc $72{ }^{\circ} \mathrm{C}$-os extenziós lépésből álló ciklus, valamint egy 30 perces $72^{\circ} \mathrm{C}$-os extenziós lépés követett.

A mikroszatellitet tartalmazó fragmentumok feldúsításához $6 \mu 1$ PCR terméket $75 \mu$ mol 5' biotint tartalmazó $(\mathrm{CT})_{12}$ oligonukleotiddal elegyítettem $30 \mu l$ végtérfogatban. A $(\mathrm{CT})_{12}$ oligonukleotidot hozzáhibridizáltattam a PCR fragmentumok mikroszatellit szakaszaihoz a keveréket 7 percig $94^{\circ} \mathrm{C}$-on tartva, majd $0,1{ }^{\circ} \mathrm{C} / \mathrm{s}$ sebességgel szobahőmérsékletre hütve. Az így biotin fragmentum jelölést kapott fragmentumokat streptavidin-konjugált mágnesgyöngyökkel (Dynabeads M-280 Streptavidin; Invitrogen, Carlsbad, CA, USA) szelektáltam mágnes segítségével a gyártó utasításait követve. A gyöngyök felszínét előre lekötöttem egy indifferens PCR-termékkel (pre-blocking), melynek célja az volt, hogy később ki lehessen szelektálni a nem kívánt módon biotin molekulán keresztül mikroszatellitet-fragmentumot nem tartalmazó, de a Sterptavidinborítású gyöngyökre kapcsolódott DNS molekulákat. Ezzel a megoldással azt próbáltam elérni, hogy ezek az aspecifikus DNS fragmentumok lehetőség szerint ne tartalmazzák a „TOP” oligonukleotid szekvenciáját, és így később egy „TOP” primerrel végzett PCR reakció során az arányukat le lehessen csökkenteni. Az aspecifikus DNS szakaszok kiszürésével a későbbi szekvenálás hatékonyságát próbáltam megnövelni.

A lekötött felszínű Streptavidin-konjugált mágnesgyöngyökhöz hozzáadtam a biotin-jelölésű oligonukleotidokhoz hibridizált DNS-t, majd háromszor öblítettem $1 \times$ Binding and Washing pufferrel, és a DNS-t felszuszpendáltam $100 \mu 1$ vízben. A felszuszpendált DNS fragmentumokra PCR reakciót végeztem a „TOP” oligonukleotidnek mint primenek a felhasználásával a fentebb leírttal azonos módon. A hosszabb DNS fragmentumok szelektálásának céljából a PCR terméket 1 \%-os etidium-bromid festésű TAE agaróz gélen elektroforetikusan futtattam 1 órán keresztül $60 \mathrm{~V}$ tal. A 200 bp-nál hosszabb PCR-termékeket tartalmazó géldarabot kivágtam, és a DNS-t kitisztítottam EZ-10 Spin Column DNA Gel Extraction Kit (Bio Basic, Markham, Canada) használatával $25 \mu$ l végtérfogatban. A méret-szelektált mikroszatellit-dúsított DNS-szakaszokat T4 DNS ligázzal plazmid vektorba ligáltam (pGEM T-easy Vector System, Promega). A ligált plazmid vektorokat ezt követően DH5 $\alpha$ E. coli kompetens sejtekbe transzformáltam Z-Competent E. coli Transformation Kit (Zymo Research, Irvine, CA, USA) segítségével. 48 pozitív klónból tisztítottam ki a plazmidot EZ-10 Spin Column Plasmid DNA Kit (Bio Basic) használatával. Ezek a plazmidok ABI BigDye Terminator 3.1 kit (Applied Biosystems) szekvenáló reakciót követően ABI 3100 (Applied Biosystems) kapilláris elektroforézis készüléken kerültek szekvenálásra.

A 48 szekvencából 18 tartalmazott >10 mikroszatellit ismétlődést, ebből hatnak a végén nem volt primer tervezéshez elég hosszú mikroszatellit-határoló régió. A maradék 12 szekvenciára 
manuálisan terveztem forward és reverse primereket. A tervezett primerekkel a PCR reakciók és a fragmenshossz-analízis a rokon fajokból átvett markerekkel azonos módon történt.

A S. josikaea-ban megfelelően használható mikroszatellit lókuszokat 179 mintán amplifikáltam. A PCR amplifikációkat a következő összetevőkkel készítettem $20 \quad \mu 1$ rakciótérfogatban: $1 \times\left(\mathrm{NH}_{4}\right)_{2} \mathrm{SO}_{4}$-t tartalmazó Taq DNS polimeráz puffer (Thermo Scientific), $2 \mathrm{mM} \mathrm{MgCl} 2,0,2 \mathrm{mM}$ dNTPs, 1,0 $\mu \mathrm{M}$ 5' 6-FAM fluoreszcens jelölésü forward primer, 1,0 $\mu \mathrm{M}$ reverse primer, 0,5 U recombinant Taq DNS polimeráz (Thermo Scientific) és 1,5 $\mu 1$ templát DNS egy PTC 200 (MJ Research) készülékben. A PCR reakciók 5 perc kezdeti denaturációval indultak $94{ }^{\circ} \mathrm{C}$-on, ezt 30 darab $94{ }^{\circ} \mathrm{C}$-os dentaurációból, $52{ }^{\circ} \mathrm{C}$-os tapadási lépésből, $72{ }^{\circ} \mathrm{C}$-os elongációs lépésből álló ciklus követte, melyekben minden lépés $30 \mathrm{~s}$ ideig tartott. A végső elongációs lépés 72 ${ }^{\circ} \mathrm{C}$-on történt 30 percig. A PCR termékek egy ABI 3100 (Applied Biosystems) készüléken kerültek elektroforetikus elválasztásra GenScan - 500 ROX (Applied Biosystems) belső méret standard használatával.

\subsection{Az adatelemzés módszerei}

\subsubsection{A Syringa josikaea divergencia idejének kiszámítása molekuláris óra analízissel}

Fosszilis lelet alapon időkalibrált filogenetikai törzsfa készítésével számítottam ki a $S$. josikaea elválását a rokon fajoktól. Az analízist ETS és ITS szekvenciák alapján készítettem, és a törzsfát a Syringa és Fraxinus genus elválásának minimális korát bizonyító fosszilis leletek alapján datáltam.

Az analízis a $S$. josikaea 4.3.1. fejezetben leírt módon generált ETS-ITS szekvenciáival készült, a fajon belül variábilis három nukleotid pozíció a $S$. josikaea-ból származó egy mintában konszenzus szekvenciaként szerepelt. Az analízis a $S$. josikaea mellett tartalmazta az összes Syringa és Ligustrum egyedet, amelyeknek az ETS és ITS szekvenciái is megtalálhatók a GenBank adatbázisban, továbbá négy Fraxinus faj ETS-ITS szekvenciáit és külcsoportként a Jasminum nudiflorum Lindl. ETS-ITS szekvenciáit. Az analízis így a S. josikaea mintáján kívül összesen 29 faj szekvenciáit tartalmazta (F5. táblázat).

Az ETS és ITS szekvenciákat külön-külön illesztettem egymáshoz a Gblocks v0.91b szoftverrel a phylogeny.fr online felületén keresztül (Castresana 2000; Dereeper et al. 2008). A szoftver a szekvenciák illesztése mellett a bizonytalanul illeszthető szakaszokat is automatikusan eltávolította. Az ETS és ITS illesztések filogenetikai egyezőségét incongruence lenght difference test (ILD; Farris et al. 1995) segítségével vizsgáltam a PAUP 4.0b10 (Swofford 2002) szoftverben 
partition homogeneity test használatával 1000 ismétléses heurisztikus kereséssel és parszimónia feltétellel.

Az ETS és ITS illesztésekre külön-külön megállapítottam az őket legjobban leíró nukleotid szubsztitúciós modellt a JModelTest v.0.1.1 (Posada 2008) használatával Akaike Information Criterion alapján 88 lehetséges modell közül.

A molekuláris óra analízist a BEAST 1.7.5 Markov-lánc Monte Carlo (MCMC) alapon müködő filogenetikai szoftverrel végeztem (Drummond et al. 2012). A program beviteli fájlját a BEAST programcsomagjához tartozó BEAUti 1.7.5 szoftveren keresztül készítettem el. Az ETS és ITS szekvencia illesztéseket két elkülönített adat alegységként (data subset) vittem a programba külön-külön a nekik legmegfelelöbb szubsztitúciós modellel, a két adatalegységre számított törzsfákat egyesítve. A Jasminum nudiflorum mintát állítottam be külcsoportnak a FraxinusSyringa-Ligustrum fajok monofiletikussá kényszerítésével, amely leszármazási kapcsolatot korábbi tanulmányok állapítottak meg (Wallander és Albert 2000; Li et al. 2002). Kezdö törzsfaként random fát állítottam be Yule-folyamat prior törzsfa evolúciós modellel (Gernhard 2008), melyet olyan esetekre ajánlanak, amikor a vizsgált minták külön fajokból származnak. Az MCMC lánc hosszát előzetes próbafutás alapján $10^{7}$ generációnak állítottam be, elmentve minden $10^{3}$ generáció eredményét. A próbafutást követően a generációk számát úgy növeltem, hogy a log-fájban található posterior effektív minta méret (effective sample size, ESS) 200 kritikus érték fölötti számot érjen el, ezt a Tracer 1.5 szoftverben (Rambaut és Drummond 2009) ellenőriztem. Ez az érték az MCMClánc generációi során kapott független értékeket határozza meg (ha túl alacsony, akkor a lánchossz növelésére van szükség megbízható eredmények eléréséhez).

A szoftver kézikönyve által ajánlott módszer szerint először molekuláris óra típusként korrelálatlan lognormál relaxált órát (uncorrelated lognormal relaxed clock) állítottam be molekuláris óra kalibráció nélkül, 1,0-ra állított szubsztitúciós rátával. Ez a molekuláris óra beállítás alkalmas annak felmérésére, hogy a leszármazási ágak között mekkora a szubsztitúciós ráta eltérése. Ha a törzsfa ágak szubsztitúciós rátáinak (uncorrelated lognormal relaxed clock rate, ucld értékek) eltérése alacsony (konfidencia intervallumukat mérve a ucld.stdev/ucld.mean 0-hoz közelít), akkor nincs szubsztitúciós ráta eltérés az adatokban, ha ez 0-nál jelentősen magasabb, akkor az adatok nem felelnek meg a szigorú molekuláris óra (strict molecular clock) feltételeinek. Utóbbi esetben relaxált molekuláris óra használata ajánlott, amely modell megengedőbb a szubsztitúciós ráta heterogenitására nézve (Lemey és Posada 2010). A szubsztitúciós ráták eltérését a Tracer 1.5 szoftverben vizsgáltam.

A molekuláris óra kalibrációs pontjaként a legidősebb ismert Fraxinus fosszilis leletet használtam (Call és Dilcher 1992; Suzuki és Watari 1994). Ezzel a fosszíliával azt az időpontot 
határoztam meg, amikor a Fraxinus és Syringa nemzetségek már bizonyosan kialakultak és elváltak egymástól. A fosszília kora alapján a Fraxinus és Syringa-Ligustrum fajok legalább 40 millió éve elváltak. A programban négy Fraxinus fajnak a Syringa-Ligustrum fajoktól való elválását, a legközelebbi közös ős létezésének időpontját (time of most recent common ancestor; tmrca) normál eloszlású $40 \pm 3$ millió év standard deviációval állapítottam meg Besnard et al. (2009) illetve Hong-Wa és Besnard (2013) munkáját követve.

A kalibrált molekuláris óra analízist háromszor futtattam le azonos beállításokkal, és az eredmény log fájlokat LogCombiner 1.7.5 szoftverrel (Drummond et al. 2012) egyesítettem $20 \%$-os burnin-period alkalmazásával $\left(6 \times 10^{6}\right.$ generáció), majd TreeAnnotator 1.7.5-ben (Drummond et al. 2012) szerkesztettem Maximum Clade Credibility törzsfát a leszármazási csomópontok magasságára keep target height módot választva $50 \%$ posterior probability limittel. A kapott törzsfát FigTree 1.4 (Rambaut 2012) progamban ábrázoltam a kládok posterior probability értékeivel, a leszármazási vonalak elágazási pontjainak korát mint átlagos magasságot (mean node heights) és ezek $95 \%$ posterior density eloszlását feltüntetve.

\subsubsection{Szekvencia variabilitás a Syringa josikaea populációk közt}

A S. josikaea populációi között variábilis ETS és ITS régiók szekvenciáit egyedenként összefüztem. Ezt azért tehettem, mert az ETS és ITS szekvenciákat mindössze a 18S RNS-t kódoló DNS szakasz választja el a genomban, és így ezek egy lókusznak foghatóak fel. A szekvenciák variábilis pozíciói alapján riboszomális genotípusokat, ún. ribotípusokat határoztam meg. Mind a 62 egyed ribotípusát meghatároztam az egyedenként összevont ETS és ITS szekvenciáik alapján a GenAlEx 6.5 (Peakall és Smouse 2012) szoftverrel. Külcsoportként meghatároztam a két legközelebbi Syringa faj, a $S$. villosa és $S$. wolfii ribotípusát is, melyek ETS és ITS szekvenciái Li et al. (2002) munkájából származtak. Minimum-spanning haplotípus hálózatot készítettem a ribotípusok alapján az Arlequin 3.5 (Excoffier és Lischer 2010) szoftverrel. Ezzel az volt a célom, hogy megállapítható legyen a $S$. josikaea esetében a legősibb ribotípus. A haplotípus hálózatot a HapStar (Teacher és Griffiths 2011) szoftverrel ábrázoltam.

A példányok egy részében a szekvenciák elektroforetogramján egy-egy variábilis pozíción dupla-csúcsok jelentek meg azt jelezve, hogy ezekben a példányokban két különböző ribotípus is jelen van. Ezeket az egyedeket úgy kezeltem, hogy bennük fele részben egyik illetve másik ribotípus van jelen. A populációkban jelenlevő ribotípusokat összesítettem, és térképre vetítettem a ribotípusok térbeli eloszlását. 


\subsubsection{Mikroszatellit markerek tesztelése és fejlesztése}

Megállapítottam a variábilis lókuszok teljes mérettartományát, megszámoltam lókuszonként a jelenlevő alléleket és genotípusokat. Kiszámoltam az megfigyelt (Ho) és várt (He) heterozigótaság értékét, valamint ezekből a beltenyésztési együtthatót $\left(F_{I S}\right)$ az Arlequin 3.5. szoftverrel. Szintén ezzel a szoftverrel a 20-20 ukrajnai és romániai mintára külön-külön kiszámítottam a Hardy-Weinberg egyensúlytól való eltérést Markov chain exact test (Guo és Thompson 1992) segítségével $10^{6}$ generációval, melyből az első $10^{5}$ generáció nem került figyelembevételre (dememorization steps).

A 40 egyed genotipizálását követően a rokon fajokból átvett és a saját tervezésü markerekkel meghatároztam az azonos multilókusz genotípusú (azonos MLG) egyedeket (exact match of multilocus genotypes) és az egyes genotípusok ismételt előfordulásának valószínűségét DNS profil valószínüségi teszttel (DNA profile probability test, Parks és Werth 1993 alapján) a GenAlEx szoftverrel.

\subsubsection{A mikroszatellit adatok kiértékelése és adatelemzése}

\subsubsection{Az egy klónhoz tartozó minták összevonása}

Mivel az élőhelyén összefüggő klonális állományokat alkotó S. josikaea populációkban a mintavételkor sok esetben nem lehetett biztosan eldönteni az egyedek határait, ezért valószínü volt, hogy egyes szomszédos minták valójában genetikailag azonos egyedektől származnak. A populációgenetikai analízisekben egy-egy egyed felülreprezentáltsága az allél és a genotípus gyakoriságok valóságtól való eltérését okozná, és torzítaná az eredményeket. Ezért az egy MLG-ú szomszédos mintákat azonos genetből származónak tekintettem, hogy az adattáblában minden egyes egyed csak egy tételként szerepeljen. A gyakorlatban ez úgy történt, hogy minden populációnál meghatároztam az egyező MLG-ú egyedeket a GenAlEx programmal, és a szomszédos azonos MLG-ú mintákat összevontam. A továbbiakban minden analízist az összevont adatokkal végeztem, amelyben minden egyes egyedet egy minta reprezentált.

A mikroszatellitek PCR fragmentumait a GeneMapper szoftver (Applied Biosystems) 3.7-es verziójával értékeltem $\mathrm{ki}$ az összes fragmenscsúcsot egyenként áttekintve. A mikroszatellit markerek használata során a PCR fragmentumokban esetlegesen megjelenő dadogó csúcsok az allélek helytelen meghatározását eredményezhetik, illetve a primer kitapadási szakaszain végbemenő mutációk nem amplifikált alléleket (null-alléleket) okozhatnak, amelyek homozigóta túlsúlyként jelentkeznek a populációkban. A dadogó csúcsok okozta genotípus félrehatározásokat és null-allélek jelenlétét a MICRO-CHECKER 2.2.3 (Van Oosterhout et al. 2004) szoftverrel ellenőriztem. 
Vizsgálatom csupán négy mikroszatellit marker analízisén alapul. Kevés marker alacsony felbontóképességhez vezethet, amellyel kisebb genetikai különbségek nem válhatnak kimutathatóvá. A markerek megfelelő száma azonban nem határozható meg előre, hiszen ez függ a mintaszámtól, a markerek variabilitásától és az adott faj populációinak történetétől. Ezért megvizsgáltam, hogy (1) a markerek mennyire képesek a populációk azonosítására; az egyedek mekkora része kerül genetikailag a valós saját populációjába population assignment teszt (Paetkau et al. 1995) alapján, illetve (2) mekkora a felbontóképessége a markereknek; az összes minta mekkora hányada rendelkezik egyedi MLG-sal.

A population assignment tesztet a GenAlEx programmal végeztem az összes egyed figyelembe vételével. A szoftver leírása alapján javasolt populációnként egy minta kihagyását (leave one out option) nem tudtam alkalmazni, mivel több populáció is csupán egy egyedből állt.

A markerek egyedi felbontóképességének teszteléséhez a teljes populáció mintán meghatároztam az azonos MLG-okat. Minél kevesebb azonos MLG-ú egyed jelenléte a markerek megfelelő felbontóképességét jelenti, míg azonos MLG-ú egyedek nagy számú előfordulása azt jelentené, hogy a markerek felbontóképessége alacsony.

\subsubsection{A populációk genetikai diverzitása}

A populációgenetikai analízisek nagy (populációnként 20-30 egyed) mintaszámokat követelnek meg, populációnként lehetőleg egyenletesen elosztva. Esetünkben a kívánt mintaszámok csak kevés esetben teljesültek az általánosan kicsi, több esetben csupán egy vagy néhány egyedszámú populációknak köszönhetően. A változó populáció méretek miatt a mintaszámok nagyfokú egyenetlensége mellett az egyes populációk mintáinak a gyüjtési módja is különbözött az esetünkben; a kisebb $(<10)$ egyedszámú populációknál teljes, míg a nagyobb populációknál random mintavétel készült. Ezek következtében az olyan egyedszám-standardizációs módszerek, mint az ismételt random részmintázás (repeated random subsampling) vagy a hozzá hasonló rarefaction módszer, melyben a nagyobb mintaszámú populációk jellemzőit egy kisebb részpopuláció méretére kalkulálják vissza, nem lennének megoldhatóak (Petit et al. 1998; Leberg 2002). A hagyományos populációgenetikai számítások (pl. F-statisztika, Nei-féle genetikai távolság) nem is végezhetők el az egy genotípusból álló populációkra, amellett, hogy az egészen kis populációk esetében az ilyen számítások eredményét nagymértékben sztochasztikus folyamatok befolyásolnák. A populációk kicsi és egyenetlen mintaszámai miatt a populációk diverzitására és különbözőségére közvetlenül nem készítettem analízist, ehelyett minden analízis elsődlegesen az egyedi vagy regionális genetikai jellemzőkre épült.

Az egyes egyedeket bayesi nemhierarchikus klaszterozó (Bayesian nonhierarchical clustering) eljárással rendeltem különböző genetikai csoportokhoz a STRUCTURE 2.3.4 (Hubisz et 
al. 2009) szoftver felhasználásával. A módszer lényege, hogy a program genetikai csoportokhoz rendel hozzá minden egyes egyedet úgy, hogy a genetikai csoportokon belüli Hardy-Weinbergegyenlőség és kapcsoltsági-egyensúly maximalizálva legyen. Az egyedek klaszterekhez való hozzárendelése többféle elöre beállított csoport számnál történik. A módszer előnye, hogy a kapott eredmények függetlenek az egyes egyedek származási helyétől és a populációk méretétől (a jelen dolgozatban alkalmazott beállítások esetén). Az egyedek genetikai klaszterekhez való hozzárendelése mellett a klaszterek legvalószínübb számának meghatározása is az analízis során történik. Az analízis során admixture modellt, korrelált allél frekvenciákat (correlated allele frequencies) alkalmaztam. Az analízist 2-15 számú klaszterrel (K) végeztem, minden számítást 20szor ismételve $2 \times 10^{5}$ burnin és $10^{6} \mathrm{MCMC}$ generációt alkalmazva. Ezek a beállítások és az adatok interpretációja megfelelnek a Gilbert et al. (2012) által ajánlottnak. Az adatokra legjobban illő klaszterszámot a STRUCTURE HARVESTER (Earl és vonHoldt 2012) alkalmazásával a STRUCTURE használati útmutatója (Hubisz et al. 2009) által ajánlott $\ln \mathrm{P}(\mathrm{D}) / \mathrm{K}$ módszerrel és az Evanno-módszerrel (Evanno et al. 2005) határoztam meg (a módszerek müködési elvének leírását lásd az idézett szakirodalmakban). Az azonos K klaszterszámmal végzett 20 ismétlés eredményében az egyes klaszterek felcserélődését (label switching) és az egyes ismétlések közti véletlen különbségeket (multimodality) a CLUMPP szoftver Greedy opciójával küszöböltem ki illetve átlagoltam (Jacobsson és Rosenberg 2007).

Az egyes egyedek klaszterekhez való hozzárendelését ábrázoltam kettőtől az optimális klaszterszám plusz egy klaszterszámig. A grafikonon szerepeltettem minden egyes egyed különböző klaszterhez való tartozásának valószínüségét (biplot). Az optimális klaszterszám esetében a populációkra átlagolt klaszterbesorolásokat térképen ábrázoltam kördiagramokkal.

\subsubsection{A populációk genetikai különbségei földrajzi helyzetük figyelembevételével}

A populációk STRUCTURE analízis alapján meghatározott genetikai jellege alapján határoztam meg a genetikai típusok választóvonalait és határait. Ehhez a Barrier 2.2 szoftvert alkalmaztam (Manni et al. 2004), amely egy egyszerủ algoritmust használ földrajzi választóvonalak (barriers) meghatározására a populációk közti különbségértékek alapján. Müködésének lényege, hogy a populációk földrajzi elhelyezkedése alapján köztük Delaunay háromszögelést végez, és Voronoï-poligonokat számít (Voronoï 1908), majd a populációk közti határvonalak mentén rajzolja ki a földrajzi választóvonalakat a szomszédos populációk genetikai távolság értékei alapján. A szoftver a müködési elvét egy konkrét példán keresztül az F6. ábrán mutatom be A Barrier szoftverrel populációk közti genetikai választóvonalakat többféle populációk közti genetikai távolságot jellemző mérőszámokkal lehet használni, a módszert a STRUCTURE analízis eredményeiből kiszámított populáció genetikai távolságokkal először Thiel-Egenter et al. 
alkalmazták (2009). Ezt követve a populációk átlagos klaszterbesorolásai alapján kiszámítottam a távolságmátrixukat euklideszi távolságok alapján a SYN-TAX 2000 szoftverrel (Podani 2001). A szoftverrel az első öt genetikai választóvonalat határoztam meg. A választóvonalak számát tovább növelve nem jött létre a populációk további földrajzilag értelmezhető elkülönülése.

Az Erdélyi-Szigethegységre és Ukrajnai-Kárpátokra kiszámítottam a mikrosztellit allélok számát, az unikális allélok számát és az allél diverzitást (uHe) GenAlEx programban.

\subsubsection{A genetikai és földrajzi távolságok korrelációja}

Annak vizsgálatát, hogy a genetikai távolságok és földrajzi távolságok között milyen kapcsolat van, Mantel-teszttel (Mantel 1967) végeztem egyedek szintjén. Az egyedek közötti genetikai és földrajzi távolságából távolság mátrixot állítottam elö GenAlEx-ben. Azokhoz az egyedekhez, amelynek nem volt a terepen rögzített önálló földrajzi koordinátája, a legközelebbi ismert GPS pontokból interpolálva generáltam egy önálló földrajzi pozíciót, amely a valós pozíciójukhoz képest maximum néhány 10 méteres eltérést jelenthet. Ezzel minden egyednek önálló pozíciója lett, viszont a számítás szempontjából csupán elhanyagolható mértékű hiba keletkezett. Az egyedi szinten mért földrajzi és genetikai távolságok mátrixának korreláció-vizsgálatát 9999 randomizációs lépéssel végeztem a GenAlEx programmal. A számítást elvégeztem a teljes elterjedési területre és külön-külön az ukrajnai és romániai areára is. 


\section{Eredmények}

\subsection{A Syringa josikaea szakirodalomban jelzett állományainak felkutatása az Erdélyi-szigethegységben}

Az összes felkeresett 13 folyó- vagy patakszakaszon hét természetes populációt, továbbá egy fel nem lelt populációból származó kerti példányt találtam. A fellelt állományok helyzetét teréképen a 10. ábra mutatja. Az állományok felsorolásában megadom a földrajzi jellemzőket, a populáció méretét, élőhelyét, fontos irodalmi hivatkozásait és az esetleges egyéb információkat. Az adatokat egybegyüjtve az F7. táblázat tartalmazza.

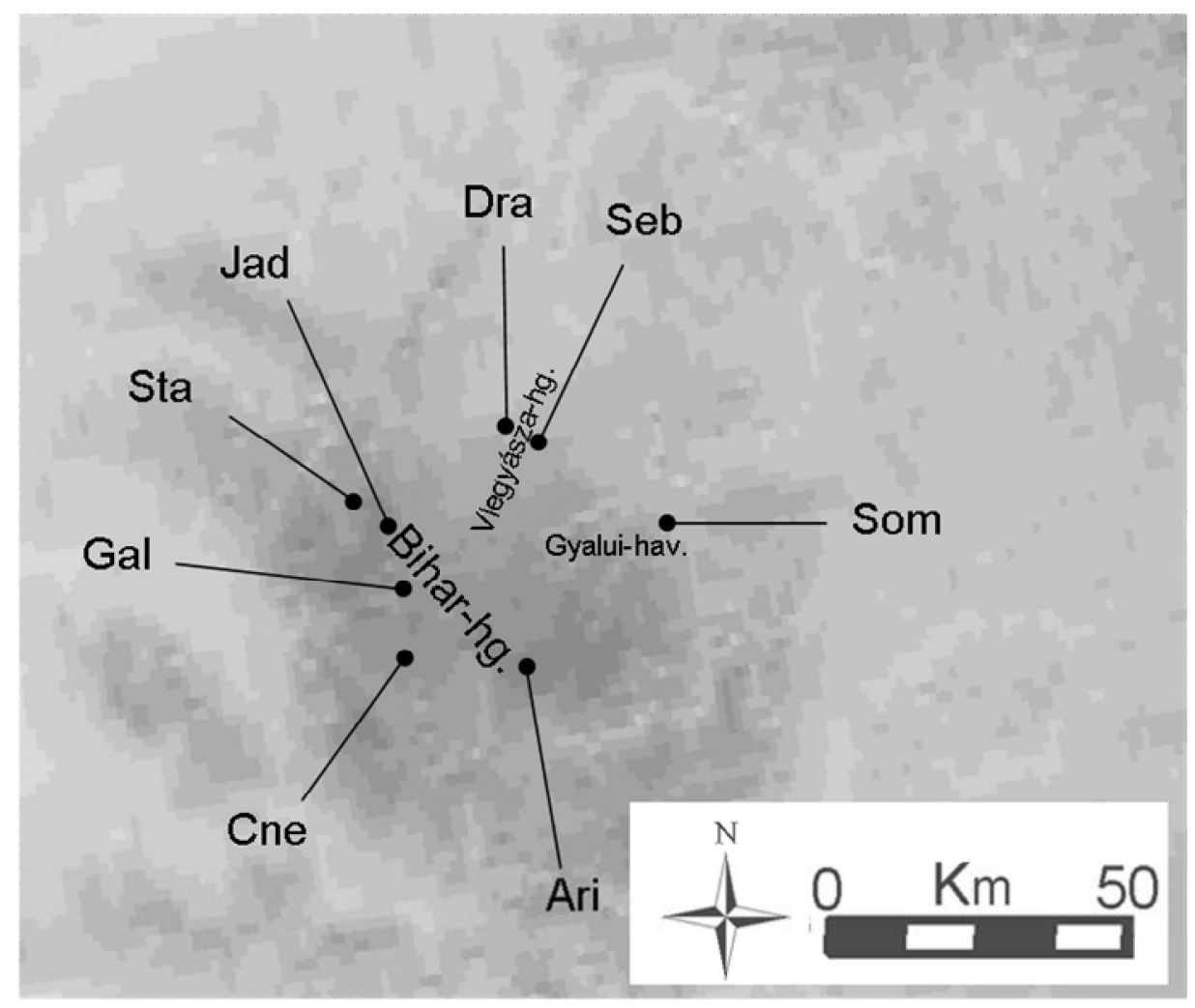

10. ábra: A Syringa josikaea általam fellelt állományai az Erdélyi-szigethegységben a hegységneveikkel. A populációk teljes nevét és leírását lásd a szövegben.

1. Valea Iadului (Jad, 11. ábra A)

Földrajzi helyzet: Bihor (Bihar) megye, Bihor megye, Remeți (Jádremete) közigazgatási határa, a Munții Bihor (Bihar-hegység) területén, a Valea Iadului (Jád-völgy) mentén a település fölött; $46,73^{\circ} \mathrm{N} 22,56^{\circ} \mathrm{E}$

Tengerszint feletti magasság, kitettség: kb. 700-900 m, keleti irányú völgy

Populáció méret: több tucat példány a patak kilométer hosszú szakaszán 
Élőhely: üde montán jellegű elegyes lomberdő övezte patak partján, kristályos pala kőzeten Hivatkozás: Flatt $(1886,1887)$

Megjegyzés: a Jád-patak folyásán Remeți-től lejjebb a Crișul Repede-be (Sebes-Körösbe) torkollásáig nem találtam a fajt

2. Stâna de Vale (Sta)

Földrajzi helyzet: Bihor (Bihar) megye, Stâna de Vale (Biharfüred) közigazgatási határa, a Munții Bihor (Bihar-hegység) területén, az üdülőtelep területén dísznövényként is és a Valea Jadului felső szakaszán; $46,69^{\circ} \mathrm{N} 22,61^{\circ} \mathrm{E}$

Tengerszint feletti magasság, kitettség: kb. 1100 m, keleti irányú völgy

Populáció méret: a patak kilométer hosszú szakaszán nagy számban

Élőhely: üde montán jellegü luc-elegyes égeres erdő és rét mozaik, a patak partján és a településen ültetve is

Hivatkozás: Borza (1936), Borza és Borza (1939)

3. Valea Drăganului (Dra, 11. ábra B)

Földrajzi helyzet: Cluj (Kolozs) megye, Tranișu (Tarányos) közigazgatási határa, a Masivul Vlădeasa (Kalota-hegység vagy Vlegyásza-hegység) területén, Valea Drăganului (Dregán-völgy), a településen természetes élőhelyéről származó kerti példány; $46,87^{\circ} \mathrm{N} 22,81^{\circ} \mathrm{E}$

Populáció méret: egy példány

Élőhely: kert

Hivatkozás: Dihoru és Negrean (2009, valószínűleg tévesen!)

Megjegyzés: A kerti példány tulajdonosa szerint a példány a település határában elterülő erdőből származik. A Valea Drăganului-ban előforduló populációt több helyi lakos is megerősítette. Nem sikerült azonban fellelni vad $S$. josikaea példányokat az elbeszélésük alapján azonosított élőhelyen. Nem találtam S. josikaea populációt Dregán-patak mentén sem, Crișul Repede-be (Sebes-Körösbe) torkollásától kb. 1000 m tszf. magasságig végigmenve.

4. Valea Sebeşului (Seb, 11. ábra C)

Földrajzi helyzet: Cluj (Kolozs) megye, Sâcueu (Székelyó) közigazgatási határa, a Masivul Vlădeasa (Kalota-hegység vagy Vlegyásza-hegység) területén, Valea Sebeşului (Sebes-völgy) település alatt; $46,84^{\circ} \mathrm{N} 22,86^{\circ} \mathrm{E}$

Tengerszint feletti magasság, kitettség: kb. 550 m, andezit, kristályos pala kőzeten

Populáció méret: néhány példány egy foltban

Élőhely: patakparti magaskórós, bükkerdő aljában

Hivatkozás: Fuss (1846), Soó (1944a) 
Megjegyzés: Sâcueu és Bologa (Sebesvár) között másutt nem került elő, ahogy a Sebeş (Sebes) folyásán feljebb egészen Răchiţele-ig (Havasrekkettyésig) sem.

5. Valea Galbenei (Gal, 11. ábra D)

Földrajzi helyzet: Bihor (Bihar) megye, Pietroasa (Vasaskőfalva) közigazgatási határa, a Munţii Bihor (Bihar-hegység) területén, Valea Galbenei (Galbena-völgy); 46,58N 22,64 $\mathrm{E}$

Tengerszint feletti magasság, kitettség: kb. 440m, nyugati irányú völgy alján, mészkő és kristályos pala kőzeten

Populáció méret: két egyed

Élőhely: üde, párás bükkerdő aljában közvetlenül a patak köves partján

Hivatkozás: Michalus (1887), Fekete és Blattny (1913)

Megjegyzés: a Cheile Galbenei (Galbena-szurdok) alsó szakaszát bejárva több egyed nem került elö

6. Valea Arieșului (Ari, 11. ábra E-F)

Földrajzi helyzet: Alba (Fehér) megye, Arieşeni és Albac (Lepus és Albák) közigazgatási határain és ezek között, a Munții Bihor (Bihar-hegység) területén, a Râul Arieș (Nagy-Aranyos) mentén; $46,46^{\circ} \mathrm{N} 22,85^{\circ} \mathrm{E}$

Tengerszint feletti magasság, kitettség: kb. 750-850 m között, keletre futó völgy alján Populáció méret: mindössze öt példány a patak tizenöt kilométer hosszú szakasza mentén elszórva Élőhely: közvetlenül az Aranyos-folyó partján, lucfenyves szélén, csillámpala kőzeten Hivatkozás: Csató (1886), Fekete és Blattny (1913)

Megjegyzés: a Riu Alba mentén nem találtam orgonát.

7. Valea Crișul Negru (Cne, 11. ábra G-H)

Földrajzi helyzet: Bihor (Bihar) megye, Poiana (Biharmező) közigazgatási határában, a Munţii Bihor (Bihar-hegység) területén, a Crișul Negru (Fekete-Körös) mentén; $46,46^{\circ} \mathrm{N} 22,63^{\circ} \mathrm{E}$

Kitettség: mészkövön, kristályos palán, nyugati irányú völgyben

Populáció méret: több tucat példány a patak kilométer hosszú szakaszán

Élőhely: üde montán jellegű elegyes lomberdő övezte patak sziklás partján, magaskórós vegetációban

Hivatkozás: Fekete és Blattny (1913)

\section{Valea Someșul Cald (Som)}

Földrajzi helyzet: Cluj (Kolozs) megye, Beliş (Jósikafalva) és Ruseşti között, a Munţii Gilăului

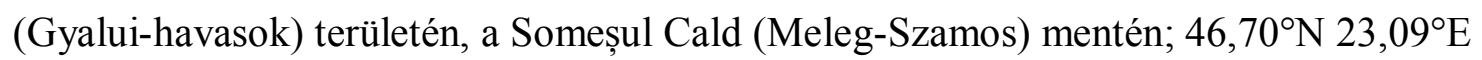

Tengerszint feletti magasság, kitettség: kb. 900m, észak-keletre, keletre futó völgy alján Populáció méret: 100-200 példány a patak mentén 
Élőhely: patakparton, zárt fenyőelegyes bükkösben, lucfenyves alján. kristályos pala kőzeten Hivatkozás: Landoz (1844), Gulyás (1907), Fekete és Blattny (1913)

Megjegyzés: rendkívül nehezen megközelíthető élőhelyek, az egykori kiterjedt area nagy részén ma duzzasztó művek vannak

Eredménytelenül kerestem a következő állományokat:

Valea Obîrșia (Obersia-völgy): az egykori élőhely helyén ma legelők vannak (F8. ábra).

Ciucea (Csucsa) és a szomszédos település Negreni (Körösfeketetó): a Crișul Repede (Sebes-Körös) mentén nem találtam, a folyó part erős antropogén hatás alatt állt (legelők, sóderbányászat).

Lorâu (Remetelórév): sem a Sebes-Kőrös mentén, sem Valea Calulujból (Ló-völgyből) nem került elö a S. josikaea.

Valea Aleu, Pietroasa (Aleu-völgy, Vaskőfalva): az irodalmi leírások helyszínén nem találtam $S$. josikaea példányokat, annak ellenyére, hogy jelentősebb élőhely átalakítások nyoma nem volt felfedezhető. 

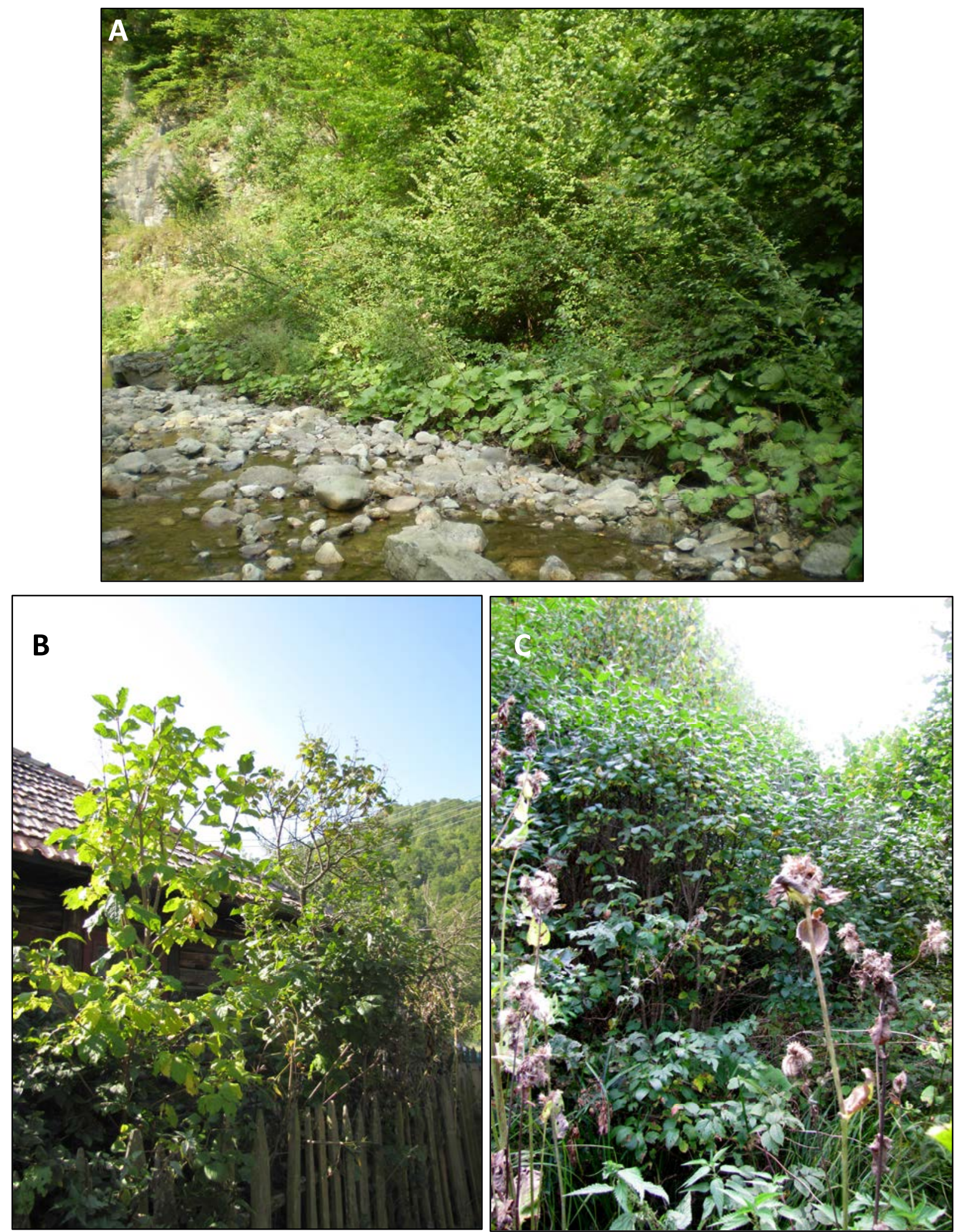

11. ábra: Syringa josikaea példányok az Erdélyi-szigethegységben: (A) patakmenti növényzetben a Jád-patak felső folyása mentén (saját felvétel, 2009.08.27.); (B) a Dregán-völgyben ház kertjében (saját felvétel, 2011.09.27.), (C) a Sebes-patak mentén patakparti magaskórós növényzetben (saját felvétel, 2011.09.27.). 

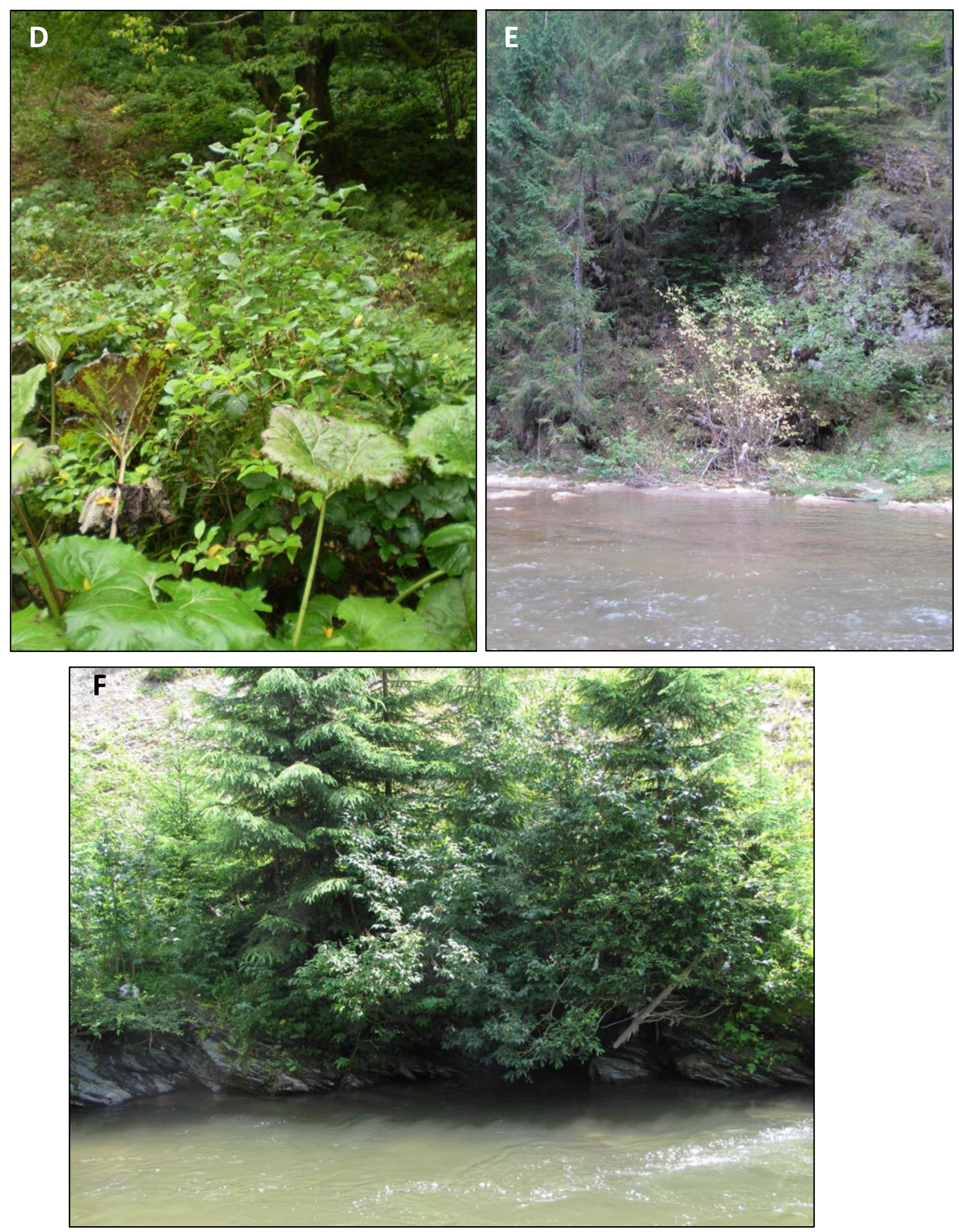

11. ábra (folytatás): Syringa josikaea példányok az Erdélyi-szigethegységben: (D) a Galbena-patak partján (saját felvétel, 2009.09.21.); (E, F) az Aranyos-völgyben ősszel sárgulva és nyáron (saját felvételek, 2012.09.27., 2010.07.05). 

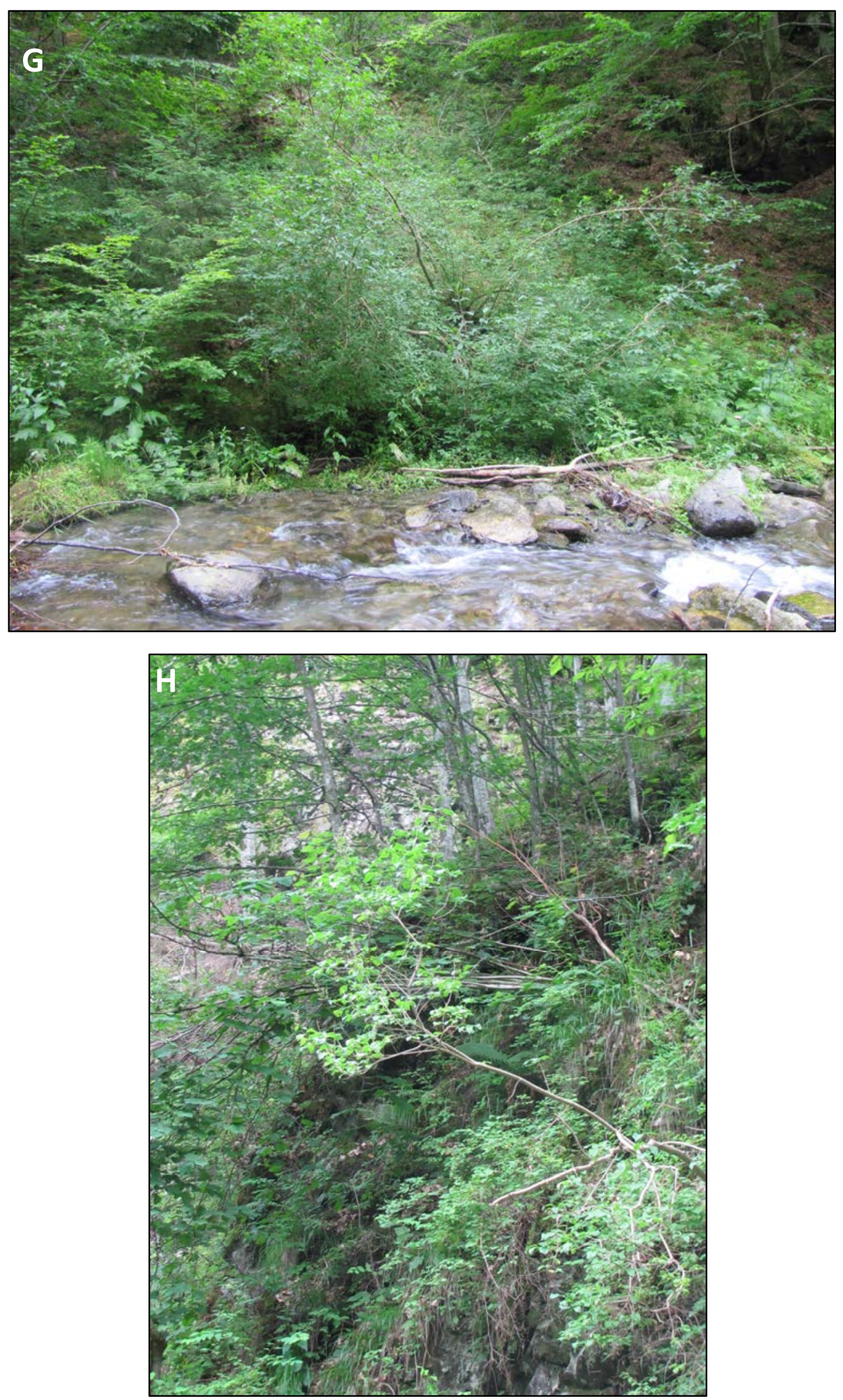

11. ábra (folytatás): Syringa josikaea példányok az Erdélyi-szigethegységben: $(\mathrm{G}, \mathrm{H}) \mathrm{a}$ Fekete-Körös-mentén, utóbbi képen nem szokványos módon, sziklafalon nőve (saját felvételek, 2010.07.04.). 


\subsection{Divergencia idő meghatározása}

A filogenetikai analízishez használt szekvencia illesztések hossza az ETS szekvenciák esetében 352 bp, az ITS szekvenciák esetében pedig 495 bp, a szekvenciák együttes hossza pedig 847 bp volt. Az illesztésekben az ETS bázis pozíciói közül 104, az ITS bázis pozíciói közül pedig 106 volt filogenetikailag informatív. Az ETS és ITS illesztések filogenetikai egyezőségét vizsgáló incongruence lenght difference test eredménye szerint nincs filogenetikai ellentmondás a két adatsor között $(\mathrm{p}=0,399)$. Az adatsorokra legjobban illeszkedő szubsztitúciós modellnek Akaike Information Criterion alapján az ETS illetve ITS szekvenciák esetében is a Tamura-Nei modell gamma eloszlással ( $\mathrm{TrN}+\mathrm{G}$, Tamura és Nei 1993) adódott. A törzsfa ágai közti szubsztitúciós ráták konfidencia intervalluma 48\%-nak adódott (ucld.stdev/ucld.mean = 0,611/1,254), ezért nem szigorú molekuláris óra beállitással, hanem uncorrelated lognormal relaxed clock modellel készítettem a időkalibrált analízist.

A bayesi filogenetikai törzsfán a $S$. josikaea erős támogatottságú kládot alkot a $S$. villosa-val és $S$. wolfii-val, melyben a $S$. josikaea leválása megelőzi az utóbbi két faj szétválását (12. ábra, F9. ábra). Az e három faj alkotta kládhoz képest a $S$. emodi kívül helyezkedik, pontos helyzete bizonytalan az alacsony támogatottságú csoportosítás miatt. Megállapítottam, hogy a $S$. josikaea divergencia ideje a $S$. villosa - S. wolfii fajpártól 1,88 millió év (konfidencia intervalluma: 0,30-4,04 millió év $95 \%$ highest posterior density confidence interval, HPD). 


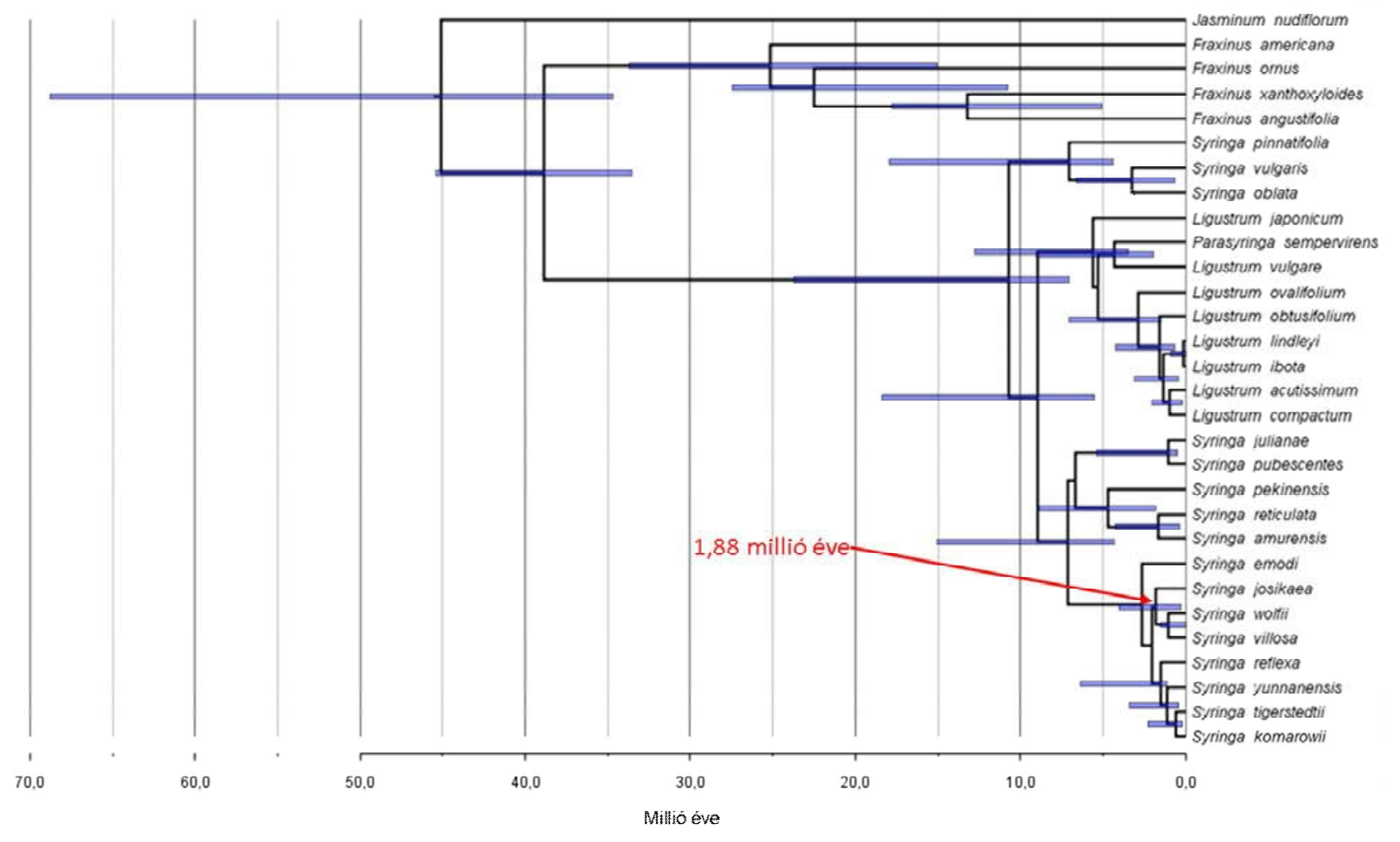

12. ábra: Bayesi filogenetikai törzsfa és divergencia idők a riboszomális ETS és ITS szekvenciák alapján BEAST 1.7.5 szoftverrel. A csomópontok korának $95 \%$-os posteriori sürüség eloszlását kék sáv jelöli a 0,8-nál magasabb posterior valószínüséggel támogatott csoportoknál. A vízszintes tengely az evolúciós ágak szétválási idejét mutatja. A Syringa josikaea divergencia ideje a legközelebbi rokon Syringa villosa és Syringa wolfii fajoktól 1,88 millió év.

\subsection{DNS szekvenciák változékonyságának tesztelése a Syringa josikaea}

\section{populációi közt}

A S. josikaea elterjedési területének szélső pontjairól származó mintákon 21 lókusz szekvenciájának fajon belüli variabilitását teszteltem (5. táblázat). Ezek között 16 kloroplasztisz intron vagy intergénikus szakasz volt, két alacsony kópiaszámú nukleáris gén intron és három riboszomális RNS-t kódoló DNS lókusz nem kódoló régiója. A PCR és szekvenálási rekació 18 lókusz esetében sikeres volt, csupán három kloroplasztisz lókusz reakcióit nem sikerült megfelelően optimalizálni. A sikeresen megszekvenált 13 kloroplasztisz lókusz hossza összesen 11135 bp, az alacsony kópiaszámú gének összesen 525 bp (Eif3E) és 555 bp (Nia-i3), míg a nukláris riboszomális gén megszekvenált szakaszai 1524 bp hosszúak voltak. Együttesen a 18 lókusz 13739 bp szekvenciát eredményezett (F10. ábra; Kiegészítés a függelékhez).

A megszekvenált 18 lókuszból csupán kettőben találtam szekvencia variabilitást, a többi 15 régióban a megszekvenált egyedek teljes szekvencia egyezőséget mutattak. A két variábilis régió az ETS és az ITS voltak, melyek a riboszomális RNS-t kódoló gének nem kódoló szakaszai közül 
valók. Az ETS 5' szakaszban egy variábilis pozíciót találtam, ahol egy báziscsere történt, míg az ITS régióban két variábilis pozíciót; mindkettő esetén báziscserével (F10. ábra).

\subsection{A variábilis DNS szakaszok fajon belüli variabilitása és eloszlása}

A két variábilis lókuszt az összes 25 S. josikaea populáció összesen 62 egyedén szekvenáltam meg. A három variábilis pozíció egyedeken belüli előfordulása alapján a S. josikaea négy ribotípusát határoztam meg (6. táblázat). A ribotípusok minimum-spanning hálózata alapján egy ribotípus (13. ábra, A) egy-egy szubsztitúciós lépésre áll a másik három ribotípustól (13. ábra, B, C, D), melyek egymástól két-két szubsztitúciós lépésre állnak. Ebben a hálózatban a S. josikaea ribotípusai közül az (A) a leghasonlóbb a legközelebbi rokon fajok, a S. villosa és S. wolfii ribotípusaihoz, amelyektől öt illetve hét szubsztitúciós lépés választja el. Az Ukrajnai-Kárpátokban mind a négy, míg az Erdélyi-szigethegységben három ribotípus (A, B, C) van jelen (14. ábra). 
6. táblázat: A Syringa josikaea ribotípusai a megszekvenált 62 egyed ETS és ITS szekvenciáinak variábilis pozíciói alapján kiegészítve a Syringa villosa és Syringa wolfii ribotípusaival.

\begin{tabular}{|c|c|c|c|c|c|c|c|c|c|c|c|}
\hline Ribotípus & \multicolumn{3}{|c|}{$5^{\prime}-\mathrm{ETS}-3^{\prime}$} & \multicolumn{8}{|c|}{$5^{\prime}-$ ITS $-3^{\prime}$} \\
\hline $\mathrm{A}$ & $\mathrm{C}$ & $\mathrm{C}$ & $\mathrm{C}$ & $\mathrm{G}$ & $\mathrm{G}$ & $\mathrm{T}$ & $\mathrm{T}$ & - & $\mathrm{T}$ & $\mathrm{T}$ & $\mathrm{C}$ \\
\hline $\mathrm{C}$ & $\mathrm{C}$ & $\mathrm{C}$ & $\mathrm{C}$ & $\mathrm{G}$ & G & $\mathrm{T}$ & $\mathrm{T}$ & - & $\mathrm{T}$ & $\mathrm{T}$ & A \\
\hline B & $\mathrm{C}$ & $\mathrm{T}$ & $\mathrm{C}$ & $\mathrm{G}$ & $\mathrm{G}$ & $\mathrm{T}$ & $\mathrm{T}$ & - & $\mathrm{T}$ & $\mathrm{T}$ & $\mathrm{C}$ \\
\hline $\mathrm{D}$ & $\mathrm{C}$ & $\mathrm{C}$ & $\mathrm{C}$ & $\mathrm{G}$ & $\mathrm{T}$ & $\mathrm{T}$ & $\mathrm{T}$ & - & $\mathrm{T}$ & $\mathrm{T}$ & $\mathrm{C}$ \\
\hline S. villosa & $\mathrm{C}$ & $\mathrm{C}$ & $\mathrm{T}$ & A & G & $\mathrm{C}$ & $\mathrm{T}$ & - & $\mathrm{C}$ & $\mathrm{C}$ & $\mathrm{C}$ \\
\hline S. wolfii & - & $\mathrm{C}$ & $\mathrm{T}$ & $\mathrm{G}$ & G & $\mathrm{C}$ & A & $\mathrm{G}$ & $\mathrm{C}$ & $\mathrm{C}$ & $\mathrm{C}$ \\
\hline
\end{tabular}

A ribotípusok meghatározása a szekvenciák illesztésével történt MEGA5 (Tamura et al. 2011) szoftverben. A S. villosa és $S$. wolfii szekvenciák Li et al. (2002) munkájából származnak; GenBank azonosító számaik: $S$. villosa ETS/ITS: AF361257/AF361283, S. wolfii ETS/ITS: AF361258/AF361284. Az S. josikaea populációi között variábilis három nukleotid pontos pozícióit az F10. ábra mutatja

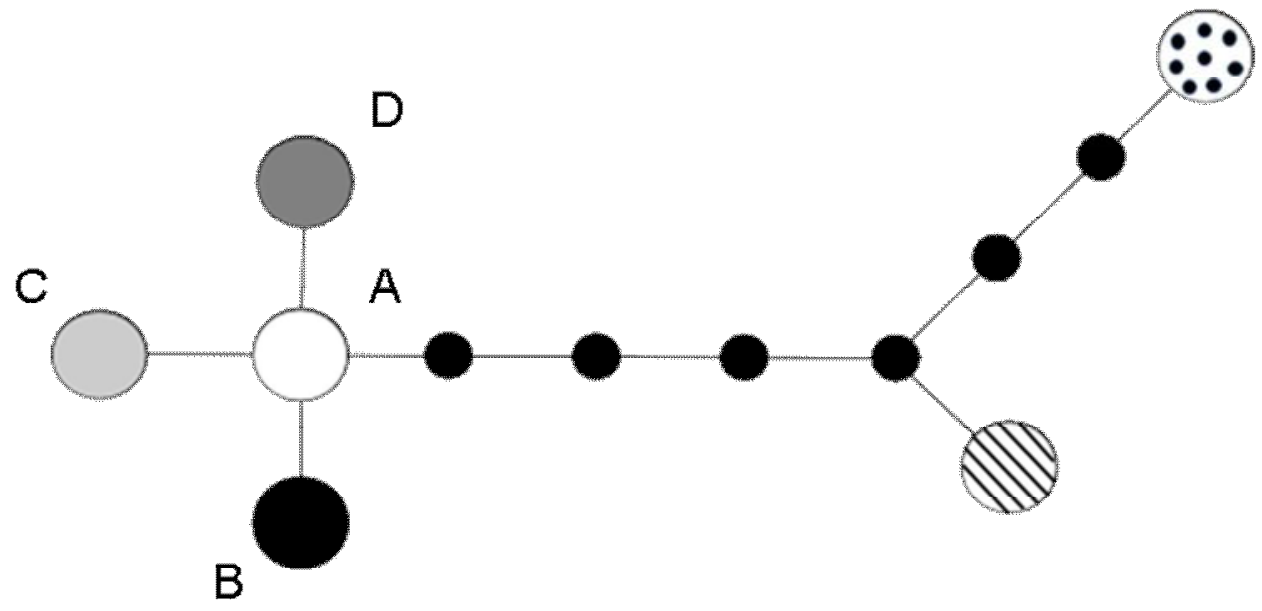

13. ábra: A Syringa josikaea ribotípusainak minimum-spanning hálózat ábrája. A S. josikaea-ban található négy ribotípust A-D betük jelzik, míg a Syringa villosa és Syringa wolfii ribotípusai csíkozva illetve pöttyözve szerepelnek. A hipotetikus ribotípusokat a kisebb fekete pontok reprezentálják. 


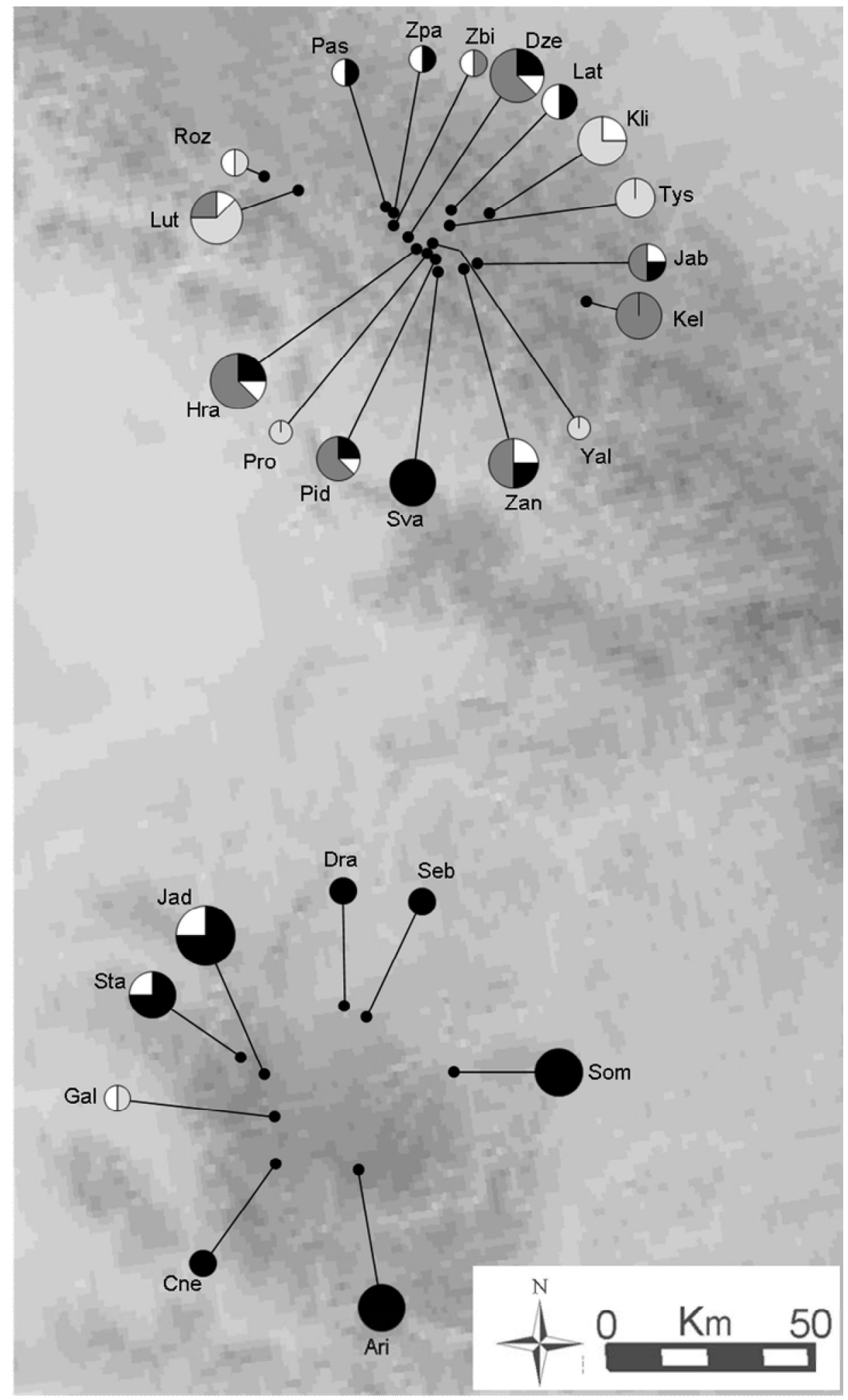

14. ábra: A Syringa josikaea ribotípusainak földrajzi eloszlása. A ribotípusok színezése megfelel a 13. ábrának. A populációkhoz tartozó kördiagramok mérete arányos a populációkban vizsgált minták számával. 


\subsection{Mikroszatellit markerek tesztelése és tervezése}

\subsubsection{Olea és Ligustrum mikroszatellit markerek használhatósága a Syringa josikaea esetében}

A tesztelt két Olea europaea és tíz Ligustrum ovalifolium mikroszatellit marker közül mindössze hatot sikerült megbízhatóan amplifikálni a S. josikaea mintáin (7. táblázat). A sikeresen amplifikált markerek közül kettő (Emo90 és Lig11) monomorfnak bizonyult az összes tesztelt mintán. A maradék három lókusz közül kettő alléljai hosszukban variábilisak voltak ugyan (Lig21, Lig101), de ezek mintázata inkonzisztens volt, több mintában is kettőnél több különböző hosszúságú PCR fragmens jelent meg. Ugyan a tesztelt 40 mintán még megfelelönek tünt a Lig21 lókusz mintázata, azonban a későbbiekben további állományok bevonásával ennek kiértékelése is problémássá vált az elektroforetikus csúcsok rendszertelen megjelenése miatt.

7. táblázat: A tesztelt Olea europaea és Ligustrum ovalifolium mikroszatellit lókuszok listája, amplifikációjuk, variabilitásuk és allél-megjelenésük jellemzői a Syringa josikaea-ban.

\begin{tabular}{|c|c|c|c|}
\hline & Amplifikáció & Polimorfizmus & $\begin{array}{c}\text { Konzekvens } \\
\text { allél-megjelenés }\end{array}$ \\
\hline \multicolumn{4}{|l|}{ Olea europaea } \\
\hline Emo13 & - & - & - \\
\hline Emo90 & + & - & - \\
\hline \multicolumn{4}{|c|}{ Ligustrum ovalifolium } \\
\hline Lig2 & - & - & - \\
\hline Lig8 & - & - & - \\
\hline Lig11 & + & - & - \\
\hline Lig14 & + & - & - \\
\hline $\operatorname{Lig} 15$ & + & + & + \\
\hline Lig18 & - & - & - \\
\hline Lig20 & - & - & - \\
\hline $\operatorname{Lig} 21$ & + & + & - \\
\hline Lig22 & - & - & - \\
\hline Lig101 & + & + & - \\
\hline
\end{tabular}

Amplifikáció: PCR reakciók sikeressége optimalizációt követően. Polimorfizmus: lókuszok hosszvariabilitása. Konzekvens allél-megjelenés: minden esetben egy vagy két allél jelenik meg, melyek hossza következetesen ismétlődik a minták között. + jelentése pozitív eredmény, - jelentése negativ eredmény. 


\subsubsection{De novo mikroszatellit markertervezés}

A tervezett 12 primer pár közül hármat vagy egyáltalán nem sikerült amplifikálni, vagy az amplifikáció eredményeként elektroforézist követően agaróz gélen egy elmosódott sáv (smear) jelent meg, viszont kilenc primer pár terméke éles csíkként jelent meg agarózon. Ez utóbbiak közül 6 lókusz egy allélt hordozott az összes vizsgált mintán, három volt hossz-variábilis. A három variábilis lókusz szekvenciája megtalálható az NCBI GenBank adatbázisában (azonosító számaik: Syr4: KC540699; Syr5: KC540700; Syr9: KC540701, Lendvay et al. 2013). Ez a három újonnan tervezett marker 36, 36 és 3+31+6 tandem ismétlődést tartalmaz (8. táblázat). Amíg a Syr4 és Syr5 markerek esetében nem jelentek meg kifejezett dadogó csúcsok az elektroforetogramon, addig a Syr9 lókusz kifejezett dadogó csúcsokat képezett, oly mértékben, hogy első pillantásra úgy tűnt, a pontos allélkiértékelést is megakadályozzák (15. ábra). Az elektroforetikus csúcsok teljes mintán való áttekintése után azonban nyilvánvalóvá vált, hogy a dadogó csúcsok mintázata minden egyes allél körül azonos, és még a két bázispár hosszkülönbségü allélek azonosítása is problémamentes.

\subsubsection{A mikroszatellit markerek jellemzése}

Az összesen négy lókusz egyenként 12-21 alléllal és 10-34 genotípussal rendelkezett a tesztelt két mintában (8. táblázat). Összesen 64 allélt hordozott a 40 minta, amely 39 egyedi MLG-t határozott meg. Csupán egy ismétlődő MLG volt a mintában, amely két szomszédos pidpolozzyai egyedhez tartozott. Ezekről azt feltételezem, hogy valójában egy klónhoz tartoznak. Ezt a feltételezést megerősíti a DNS profil valószínűségi teszt eredménye is, amely szerint ennek a bizonyos MLG-nak az ismételt előfordulási valószínűsége az adott mintán csupán a véletlennek köszönhetően $1,26 \times 10^{-8}$ lenne.

A megfigyelt heterozigótaság 0,4 és 1 , a várt heterozigótaság értéke 0,573 and 0,926 között változott (9. táblázat). A Hardy-Weinberg egyensúlytól való szignifikáns eltérést csupán egy esetben mértem a Syr9 remeţi mintájában. 
8. táblázat: A sikeresen amplifikált mikroszatellit lókuszok primerjeinek jellemzői és méret variabilitása.

\begin{tabular}{|c|c|c|c|c|c|c|c|}
\hline Lókusz név & PCR primer szekvencia $\left(5^{\prime}-3^{\prime}\right)$ & $\begin{array}{l}\text { Tandem ismétlődések } \\
\text { motívuma }\end{array}$ & $\mathrm{T}_{\mathrm{a}}\left({ }^{\circ} \mathrm{C}\right)$ & $\mathrm{N}$ & $\begin{array}{l}\text { Allél hossz } \\
\text { tartomány (bp) }\end{array}$ & $\mathrm{N}_{\mathrm{A}}$ & $\mathrm{N}_{\mathrm{G}}$ \\
\hline Lig15 & $\begin{array}{l}\text { F: AGTCTCAGGCAGATTCAAAT } \\
\text { R: GAGAATTAGTCAAATCAAATC }\end{array}$ & $(\mathrm{CT})_{25}(\mathrm{CA})_{10} *$ & 52 & 40 & $167-205$ & 14 & 10 \\
\hline Syr4 & $\begin{array}{l}\text { F: GGGTGTGTCCAA AAATTCTG } \\
\text { R: TCGAACCATTGCTTATTTCAAC }\end{array}$ & $(\mathrm{AG})_{36}$ & 52 & 40 & $201-240$ & 17 & 21 \\
\hline Syr9 & $\begin{array}{l}\text { F: GGAAATCTGCTTGTTGATACC } \\
\text { R: CACACACACACAGAGAGAGAG }\end{array}$ & $(\mathrm{TGC})_{3}(\mathrm{TC})_{31}(\mathrm{TG})_{6}$ & 52 & 40 & $234-272$ & 12 & 17 \\
\hline
\end{tabular}

$\mathrm{F}$, forward primer; $\mathrm{R}$, reverse primer, $\mathrm{T}_{\mathrm{a}}$, tapadási hőmérséklet; $\mathrm{N}$, vizsgált egyedek száma; $\mathrm{N}_{\mathrm{A}}$, allélek száma; $\mathrm{N}_{\mathrm{G}}$, genotípusok száma.

* S. josikaea-ra vonatkozó adat nem áll rendelkezésre, a táblázat adatai Ligustrum ovalifolium-ra vonatkoznak Kodama et al. munkájából (2008). 
9. táblázat: Genetikai diverzitás jellemzők a két vizsgált populációban.

\begin{tabular}{|c|c|c|c|c|c|c|c|c|}
\hline & \multicolumn{4}{|c|}{ Remeţi } & \multicolumn{4}{|c|}{ Pidpolozzya } \\
\hline Lókusz név & $\mathrm{H}_{\mathrm{O}}$ & $\mathrm{H}_{\mathrm{E}}$ & p HWE & $\mathrm{F}_{\text {IS }}$ & $\mathrm{H}_{\mathrm{O}}$ & $\mathrm{H}_{\mathrm{E}}$ & p HWE & $\mathrm{F}_{\text {IS }}$ \\
\hline Lig15 & 0,900 & 0,839 & 0,566 & $-0,062$ & 0,650 & 0,823 & 0,087 & 0,210 \\
\hline Syr4 & 1,000 & 0,887 & 0,109 & $-0,113$ & 0,650 & 0,728 & 0,121 & 0,107 \\
\hline Syr5 & 0,950 & 0,940 & 0,224 & $-0,046$ & 0,750 & 0,926 & 0,055 & 0,193 \\
\hline Syr9 & 0,550 & 0,871 & $<0,001$ & 0,321 & 0,500 & 0,650 & 0,121 & 0,231 \\
\hline
\end{tabular}

$\mathrm{H}_{\mathrm{O}}$, megfigyelt heterozigótaság, $\mathrm{H}_{\mathrm{E}}$, várt heterozigótaság; $\mathrm{p}$ HWE, Hardy-Weinberg-egyensúlytól való eltérés valószínűsége, $<0,05$ a szignifikáns érték vastagon szedve; $F_{\text {IS }}$, beltenyésztési koefficiens.

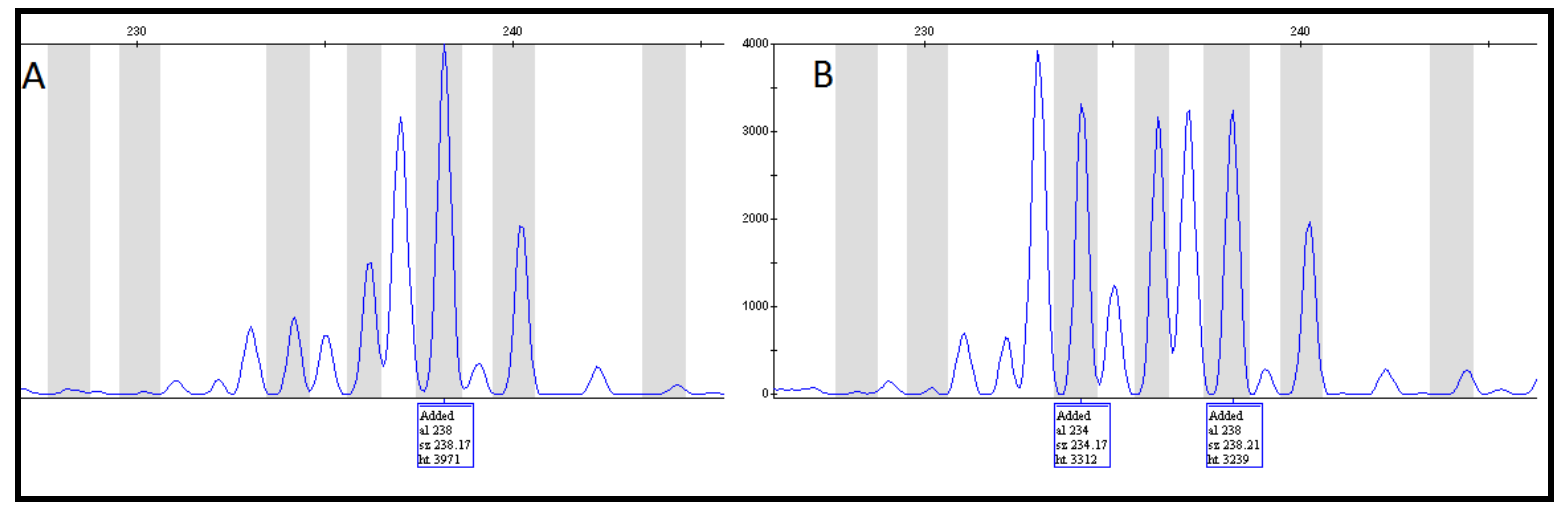

15. ábra: Két Syringa josikaea minta Syr9 lókusz alléljainak megjelenése a GeneMapper v3.7 szoftverben. A valódi allélek elektroforetikus csúcsa kijelölve, ezeket jellegzetes mintázatban dadogó csúcsok veszik körül. A dadogó csúcsok mintázata konzekvensen jelenik meg minden mintánál, amely lehetővé teszi a két bázispár hossz-különbségü allélek könnyü azonosítását is. Az (A) rész egy Syr9 lókuszra homozigóta egyedet mutat, ahol mindkét allél 238 bp hosszú, a (B) rész egy heterozigóta egyedet mutat, amelynek alléljai 234 és 238 bp hosszúságúak.

\subsection{A populációk mikroszatellit elemzése}

A MICRO-CHECKER szoftverrel végzett analízis eredménye szerint dadogó csúcsok miatt félrehatározott allélek egy populációban sem fordulnak elö, null-allélek jelenléte pedig csupán a Syr9 marker esetében három populációban (Jad, Som, Hra), a Lig15 marker esetében pedig egy populációban (Lut) valószínüsíthető.

A 179 analizált minta közül 44 egyednek a MLG-a azonos lett legalább egy szomszédos minta MLG-ával. Az Erdélyi-szigethegységből 57 mintából 8, míg az Ukrajnai-Kárpátokban 122 mintából 36 ismétlődött ily módon (10. táblázat). 
10. táblázat: Az ETS és ITS régiókon szekvenált és mikroszatellitek alapján analizált Syringa josikaea minták száma populációnként. Populációkon belül a szomszédos azonos MLG-ú mintákat azonos genethez tartozónak ítéltem.

\begin{tabular}{|c|c|c|c|c|c|}
\hline Pop & & $\begin{array}{l}\text { Szekvenált } \\
\text { eovedek }\end{array}$ & $\begin{array}{l}\text { Mikroszatellitek } \\
\text { alapján analizált }\end{array}$ & $\begin{array}{l}\text { Azonos } \\
\text { genethez }\end{array}$ & $\begin{array}{l}\text { Önálló } \\
\text { genetek }\end{array}$ \\
\hline Erdélyi- & $\mathrm{Jad}$ & 4 & 13 & 0 & 13 \\
\hline -szigethegység & Sta & 4 & 8 & 2 & 6 \\
\hline & Dra & 1 & 1 & 0 & 1 \\
\hline & Seb & 1 & 3 & 2 & 1 \\
\hline & Gal & 1 & 2 & 1 & 1 \\
\hline & Ari & 4 & 5 & 0 & 5 \\
\hline & Cne & 2 & 5 & 1 & 4 \\
\hline & Som & 4 & 20 & 2 & 18 \\
\hline & $\Sigma$ & 21 & 57 & 8 & 49 \\
\hline Ukrajnai- & Sva & 2 & 5 & 2 & 3 \\
\hline -Kárpátok & Pid & 4 & 12 & 2 & 10 \\
\hline & Pro & 1 & 5 & 1 & 4 \\
\hline & Hra & 4 & 8 & 0 & 8 \\
\hline & Yal & 1 & 6 & 1 & 5 \\
\hline & Dze & 4 & 16 & 6 & 10 \\
\hline & Zbi & 1 & 2 & 0 & 2 \\
\hline & $\mathrm{Zpa}$ & 1 & 3 & 1 & 2 \\
\hline & Pas & 1 & 2 & 1 & 1 \\
\hline & Tys & 4 & 6 & 2 & 4 \\
\hline & Lat & 1 & 2 & 1 & 1 \\
\hline & Kli & 4 & 10 & 3 & 7 \\
\hline & $\mathrm{Jab}$ & 4 & 10 & 2 & 8 \\
\hline & Zan & 2 & 3 & 0 & 3 \\
\hline & Lut & 4 & 15 & 0 & 15 \\
\hline & Roz & 1 & 7 & 6 & 1 \\
\hline & Kel & 2 & 10 & 8 & 2 \\
\hline & $\Sigma$ & 41 & 122 & 36 & 86 \\
\hline$\Sigma$ & & 62 & 179 & 44 & 135 \\
\hline
\end{tabular}

Az azonos MLG-ú szomszédos példányok összevonása után összesen 135 egyed közül mindössze három párnak lett azonos a MLG-a. Az azonos MLG-ú minta párok a Yal-Hra, Zbi-Pas valamint a Som két nem szomszédos egyede közül kerültek ki. A population assignment teszt eredménye szerint az egyedek $96 \%$-a valós populációjába lett besorolva, csupán a minták $4 \%$-a került idegen populációba. 
A STRUCTURE analízis eredményei alapján két populációnál $(\mathrm{K}=2)$ világos elválás látszik az Ukrajnai-Kárpátok és az Erdélyi-szigethegység mintái között (16. ábra $\mathrm{C}$ része). Az Erdélyi-szigethegység mintái szinte egyöntetűen az egyik populációhoz tartoznak, míg az UkrajnaiKárpátok mintái a másik populációhoz tartoznak, és utóbbiak közül csupán néhányban jelenik meg jelentősebb arányban a romániai minták klaszterja. A populációk számának eggyel való növelésével $(\mathrm{K}=3)$ megjelenő új klaszterbe kerülnek az Erdélyi-szigethegységből teljes mértékben a melegszamosi (Som), részben pedig fekete-kőrösi (Cne) és aranyos-völgyi (Ari) populációk mintái. Ez a klaszter csak elvétve és kis mértékben jelenik meg az Ukrajnai-Kárpátokban. Négyre növelve a csoportok számát $(\mathrm{K}=4)$ az Ukrajnai-Kárpátok addig domináns genetikai csoportja válik ketté, majd ugyanez ismétlődik eggyel tovább növelve a csoportok számát $(K=5)$. Hat csoportnál $(K=6)$ a romániai mintákban domináns genetikai csoport válik ketté.

A genetikai csoportok legvalószínübb számát kétféle módon határoztam meg. A STRUCTURE szoftver leírása által ajánlott módszer (Hubisz et al. 2009) alapján készült lnP(D)/K grafikonon (16. ábra A része) a legnagyobb valószínűségű K-érték (a genetikai csoportok száma) az, amelyet növelve nem nő jelentősen az $\ln \mathrm{P}(\mathrm{D})$ érték, és még kicsi a szórása. Az Evanno módszer (Evanno et al. 2005) alapján készült DeltaK/K grafikonon (16. ábra $\mathrm{B}$ része) a legnagyobb valószínűségű K-értéket ott találjuk, ahol a DeltaK-értéke csúcsot ad. Mindkét módszer alapján egyértelműen 5 genetikai klaszter léte a legvalószínűbb. 

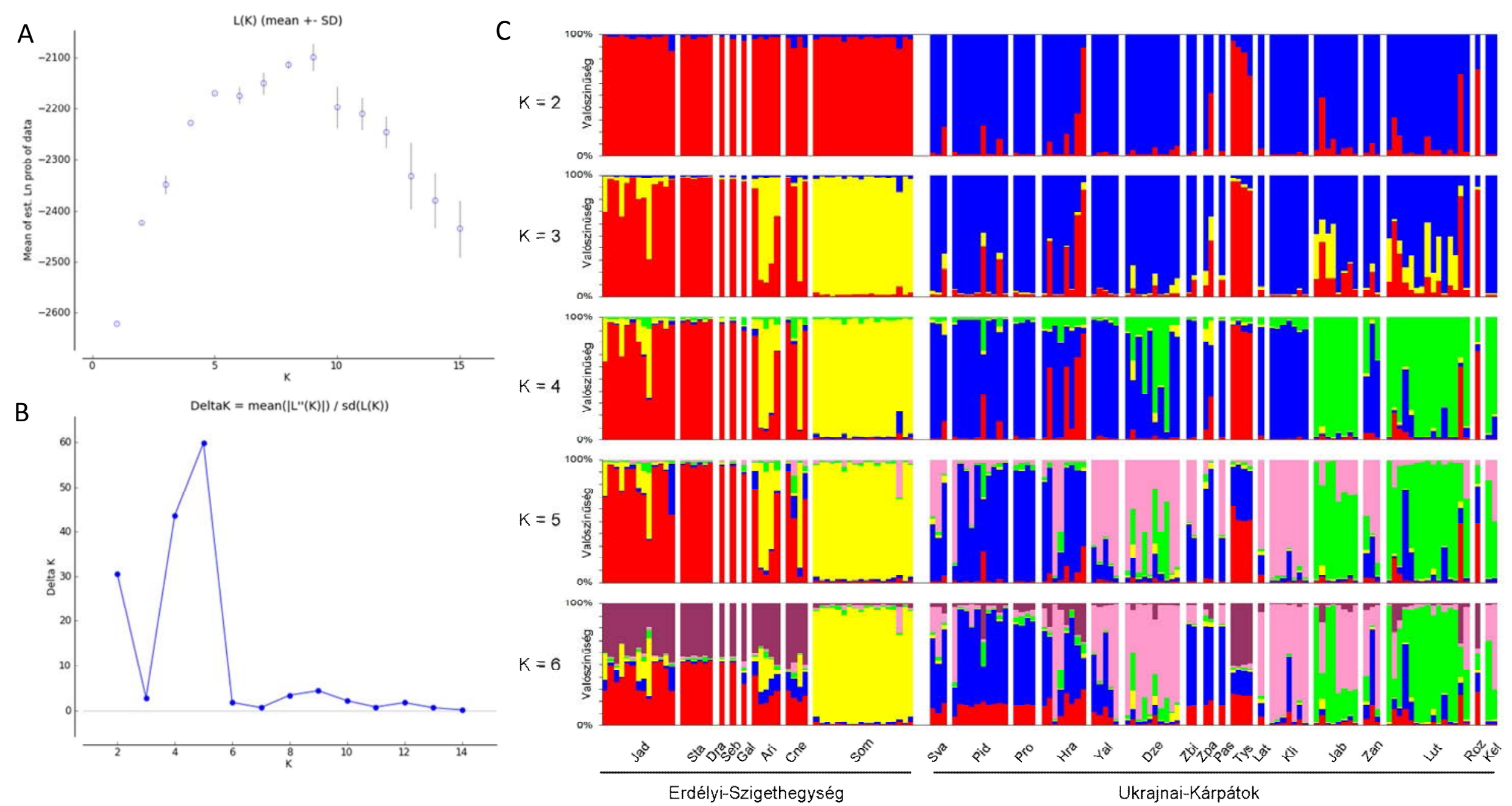

16. ábra: A STRUCTURE 2.3.4 (Hubisz et al. 2009) analízis eredményei a STRUCTURE HARVESTER (Earl és vonHoldt 2012) szoftverrel való kiértékelés alapján. $\mathrm{Az} \ln \mathrm{P}(\mathrm{D}) / \mathrm{K}$ grafikon (az ábra $\mathrm{A}$ része) és DeltaK/K grafikon (az ábra $\mathrm{B}$ része) alapján is 5 genetikai csoport $(\mathrm{K}$-érték $=5$ ) léte a legvalószínübb (az ábrák értelmezését lásd a szövegben). Az ábra (C) része a 25 populációból származó összesen 135 Syringa josikaea egyed genetikai besorolását mutatja $\mathrm{K}=2-6$ genetikai csoport alapján. 
Öt genetikai csoport feltételezésekor két genetikai klaszter jellemző az Erdélyi-szigethegységre és három az Ukrajnai-Kárpátokra. A két Erdélyi-szigethegységi csoport közül az egyik (a 16. és 17. ábrán pirossal) nagy arányban van jelen a Bihar-hegységi Sta, Dra, Seb, Gal populációkban, míg a Gyalui-havasoki Som populáció egy ettől eltérő csoportot tartalmaz (sárgával). A két genetikai típus keverékét tartalmazza az aranyos-völgyi Ari és Cne. A Jad populáció nagyobb részben a Bihar-hegységre jellemző típust tartalmazza, de kisrészben megtalálható benne a Gyalui-havasok genetikai klaszterje.

Az Ukrajnai-Kárpátokban a Latorca vízgyüjtőjében található 11 populációban két genetikai típus egyidejű jelenléte a jellemző. Az Ukrajnai-Kárpátok egyetlen nem kárpátaljai populációja, a Sztrij-patak mentén fekvő klimeci (Kli) szintén, a Latorca-völgyi populációkhoz hasonlít genetikailag.

Egy, a romániai populációkra jellemző genetikai típus (pirossal) két populációban jelenik meg jelentősebb arányban: az Ung-völgyi roztokai (Roz) és Latorca-völgyi tyshivi (Tys).

A Barrier analízis eredménye szerint a populációk közötti legjelentősebb földrajzi választóvonal (A-val jelölve az 17. ábrán) az Erdélyi-szigethegységen belül a Seb-Som populációk között indul, és a hegység három déli, délkeleti populációját választja el a többitől. A második földrajzi akadály (B) csupán kis különbséggel (lásd F11. táblázat) az Erdélyi-szigethegység és az Ukrajnai-Kárpátok kött húzódik. A harmadik, negyedik és ötödik választóvonalak az UkrajnaiKárpátokon belülre esnek. A harmadik $(C)$ a Tys populációt válaszja el körben az összes többitől. A negyedik (D) a Sztrij-völgyi Kli és Vicsa-völgyi Jab populációk közt ered, az ötödik (E) pedig a két Ung-völgyi populációt (Lut, Roz) és a Latorca-völgyi populációk egy részét (Hra, Pro, Pid, Sva) választja el a többitől.

Az Erdélyi-szigethegységben 69 allél volt jelen, melyek közül 30 csak ezen a területen volt megtalálható, és a genetikai diverzitás értéke 2,45 volt. Ezzel szemben az Ukrajnai-Kárpátokra 53 allél volt jellemző, amelyek közül 14 nem volt jelen az Erdélyi-szigethegységben. Az UkrajaniKárpátok genetikai diverzitása 1,93 volt.

A genetikai és földrajzi távolságok korrelációjára végzett Mantel-tesztek eredménye szerint a teljes elterjedési területet tekintve gyenge a korreláció $\left(r_{x, y}=0,325, p=0,001\right)$. A két különböző földrajzi léptéket vizsgálva az Erdélyi-szigethegység populációit tekintve szintén gyenge $\left(\mathrm{r}_{\mathrm{x}, \mathrm{y}}=\right.$ 0,394, $\mathrm{p}=0,001)$, az Ukrajnai-Kárpátok populációit figyelembe véve pedig elhanyagolhatóan alacsony a genetikai és földrajzi távolságok korrelációja $\left(\mathrm{r}_{\mathrm{x}, \mathrm{y}}=0,099, \mathrm{p}=0,017\right)$. 


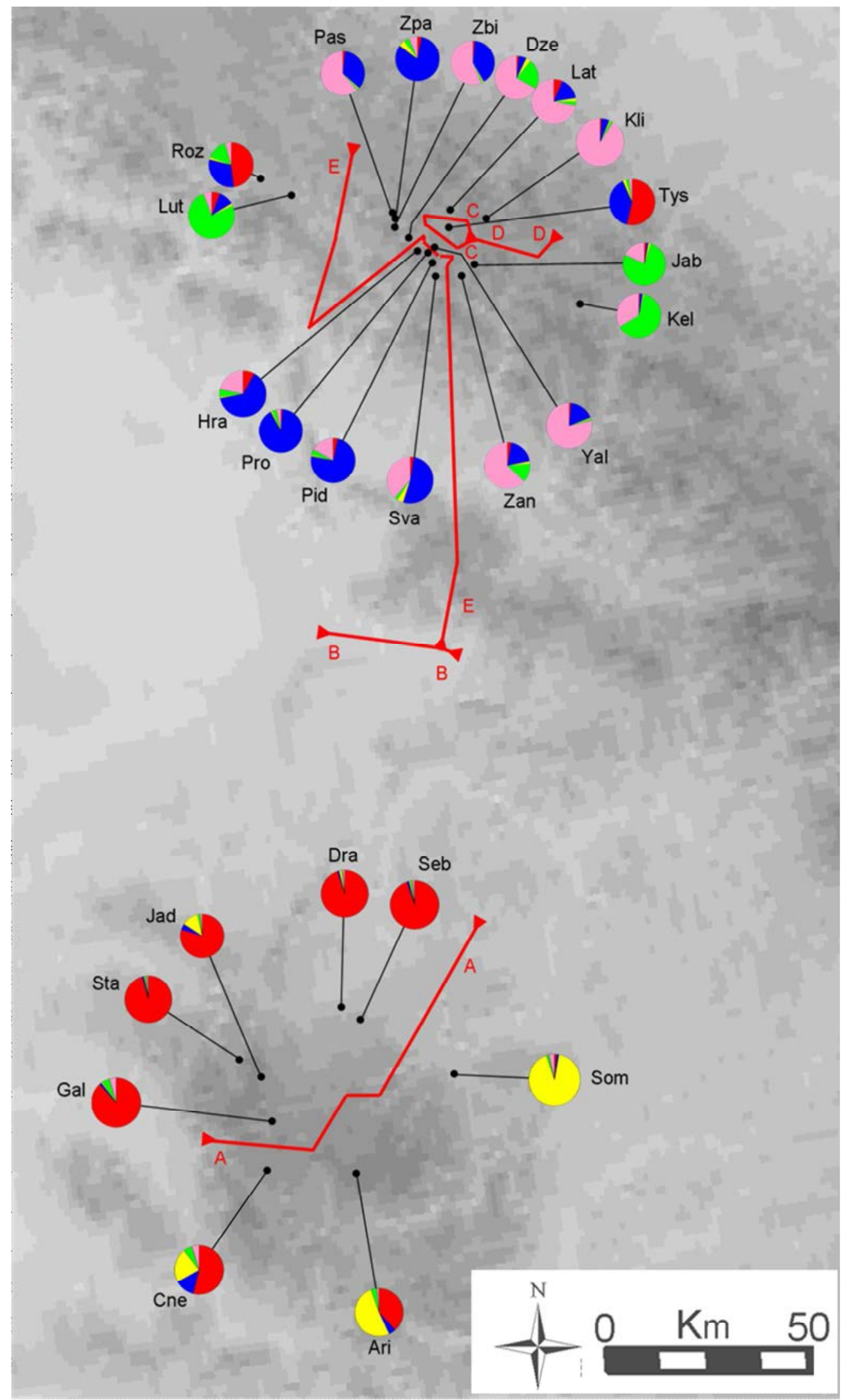

17. ábra A Syringa josikaea populációk átlagos besorolása genetikai csoportokba STRUCTURE 2.3.4 (Hubisz et al. 2009) analízis eredménye alapján, és a populációk közti földrajzi választóvonalak a Barrier 2.2 (Manni et al. 2004) analízissel a genetikai csoportok alapján. 


\section{Következtetések}

\subsection{A Syringa josikaea aktuális elterjedése az Erdélyi-szigethegységben}

Az Erdélyi-szigethegységben $S$. josikaea hét természetes állományát valamint egy nyolcadik természetes állományból származó kerti példányt sikerült megtalálni. Ez kevesebb, mint a munkám kezdete előtt számon tartott tizenegy populáció (Dihoru és Negrean 2009). Az állományok általánosan kisméretűek, négy esetben csupán néhány példányból állnak. A terepen a $S$. josikaea példányait nagy magabiztossággal tudtam azonosítani, az átkutatott területeken a megtalált példányokon kívül jelentősebb számú további egyed jelenlétének valószínűsége csekély.

A megtalált példányok populációkba sorolásánál a korábbi irodalmi elnevezéseket vettem alapul, az egy völgyben elszórt példányokat egy populációként határoztam meg (i.e. Ari). Bár populációként tartom számon őket, a csupán egy-két példányos állományok önállóan nem alkothatnak valódi szaporodási közösségeket, így ezek biológiai értelemben valódi populációknak sem tekinthetők.

\subsection{A Syringa josikaea populációk veszélyeztető tényezői az}

\section{Erdélyi-szigethegységben}

A S. josikaea jelenlegi és egykori élöhelyeinek bejárásával képet kaphattam róla, hogy milyen természeti állapotban vannak ezek a területek, milyen folyamatok befolyásolhatták negatívan a $S$. josikaea állományokat az utóbbi évtizedekben. Ennek ismerete elengedhetetlen a faj megfelelő természetvédelmi kezeléséhez. Három pontban foglalom össze tapasztalataimat olyan emberi tevékenységnek, mint az erdőgazdálkodásnak és legeltetésnek, a mütárgyak építésének és a dísznövénynek való gyüjtésnek a $S$. josikaea populációira gyakorolt hatásairól:

- Erdőgazdálkodás és legeltetés:

A populációkat körülvevő erdőkben rendszerint erdőgazdasági tevékenység folyik. A patakot kísérő állományokat több esetben is veszélyezteti az erdészeti véghasználat. Ennek során a cserjék teljes kipusztítása is bekövetkezhet. Ilyen hatás érhette a Seb és Ari populációkat, és valószínüleg ez vezetett az Aleu-völgyi és Obersia-völgyi populációk eltünéséhez. Utóbbinak az irodalomban pontosan megjelölt élőhelyén a fás patakparti vegetáció helyett maradvány fák és legeltetett gyep maradt (F8. ábra).

- Mütárgyak építése:

Az utóbbi évtizedekben a patakmenti útépítések az élőhelyek drasztikus átalakítása által jelentős hatással lehettek a S. josikaea populációira. Igazán nagy pusztítást a patakmenti támfalak építése 
végzett, ennek a tevékenységnek a Seb és Ari populációk kipusztulás-közeli állapotba jutásában jelentős szerepe lehet. Ezeket a populációkat a völgyben síturizmus céljából megindult jelentős számú építkezés továbbra is veszélyezteti. A Meleg-Szamos mentén húzódó egykori populáció egy nagy területét ma a Béli-víztározó borítja, szerencsére a patak alsóbb folyása mentén még nagyobb egyedszámú populáció él (Som).

- Gyüjtés dísznövénynek:

A S. josikaea dísznövényként is ismert, és a helyi lakosság virágzáskor gyüjti. Ez azonban csak a legkisebb populációknál pl. Seb jelenthet természetvédelmi problémát, ahol néhány virágzó hajtás leszedése is a populáció éves maghozamának jelentős csökkenését okozza. Az állományokhoz közeli falvak kertjeiben helyenként a S. josikaea vadon gyüjtött példányait is tartják (Seb, Dra, Jad). A sarjhajtások kiásása nem okozza a növények pusztulását, sőt, kedvező hatása is lehet azáltal, hogy a populációk méretét megnövelhetik a közelbe ültetett példányok. Mivel a S. josikaea természetes populációihoz közeli településeken is a látványosabb virágú $S$. vulgaris különböző fajtáit tartják, a dísznövénynek való gyüjtés valószínűleg a jövőben nem válik jelentősebbé. A kertben élő példányok növelik a kis populációk genetikai konnektivitását és reprodukciós képességét, így létük természetvédelmi szempontból is elfogadható.

A fent említett antropogén hatásokon kívül a populációk veszélyeztetettségét fokozza kis méretük, mely miatt alacsony termékenységüek, és a kis kiterjedésü állományokban nagy egy esetlegesen bekövetkező természetes katasztrófa veszélye (fakidőlés, földcsuszamlás, erdőtűz, árvíz) vagy egy valamilyen emberi tevékenység hatása.

A fenti megállapítások - az itt részletesen nem tárgyalt - Ukrajnai-Kárpátok állományaival a faj teljes elterjedési területére érvényesek. A későbbiekben maghozam és csíraképességi vizsgálatok hozzájárulhatnak a populációk állapotának és életképességének részletesebb megismeréséhez.

\subsection{A Syringa josikaea divergencia ideje}

A S. josikaea legközelebbi rokonaitól leszármazási idejét a BEAST 1.7.5 szoftver bayesi statisztikai alapon müködő filogenetikai analízisével végeztem, amelyben a törzsfa elágazási pontjaihoz időpontok lesznek hozzárendelve fosszilis kalibrációs pontok alapján. A jelen dolgozatban alkalmazott kalibrációs pont a Syringa-Fraxinus szétválási idejének felső határát meghatározó legősibb Fraxinus fosszilis maradványok 40 millió éves ( \pm 3 millió év standard deviáció) kora volt (Call és Dilcher 1992; Suzuki és Watari 1994). Habár a Syringa genuson belül is ismertek fosszilis leletek, ezek pozíciója a ma létező fajok törzsfáján bizonytalan lenne. Ezeket a Fraxinus fosszilis leleteket az Oleaceae család más nemzetségeiben is sikerrel alkalmazták molekuláris óra kalibrációs pontjaként (Olea: Besnard et al 2009; Chionanthus és Noronhia: HongWa és Besnard 2013). 
A törzsfa topológiája megfelel a morfológiai alapon és a kloroplasztisz genom filogenetikai analízise alapján tapasztaltaknak: a $S$. josikaea a series Villosae fajai közül a $S$. villosa-val és S. wolfii-val mutatja a legnagyobb fokú rokonságot (Kim és Jansen 1998; Chen 2008). Az ismert leszármazást tehát megerősíti a nukleáris riboszomális DNS szekvenciák variabilitása is. Részletesebb filogenetikai következtetésekre az itt végzett analízis nem ad lehetőséget, mivel fajonként csak egy példányt tartalmazott, és csupán két, a genomban közel elhelyezkedő, egy lókuszként felfogható DNS régió alapján készült.

Az általam végzett molekuláris óra analízis eredménye szerint (1,88 millió év 0,30-4,04 millió év HPD intervallummal) a $S$. josikaea kelet-ázsiai rokonaitól a $S$. villosa és $S$. wolfii fajpártól a Pliocén korban vagy a Pleisztocén elején vált el. Az 1,88 évet jelentő legvalószínübb időpont a Pleisztocén legkorábbi szakaszára, a 2,588-1,806 millió évek közötti Gelasi időszakra esik (International Commission on Stratigraphy 2013). Ez az időszak pedig egybe esik a Pleisztocén elején az európai Tercier flóra jelentős részének kihalásával (Járai-Komlódi 2000; Willis és Niklas 2004; Magri 2010; Postigo-Mijarra et al. 2010). Ez alapján feltételezhetjük, hogy a S. josikaea és a S. villosa - S. wolfii fajok közös öse egy eurázsiai elterjedési területtel rendelkezett, amely a Pleisztocén elején bekövetkezett lehülésekkel és szárazodással az elterjedési területe nagy részéről kipusztult (Huntley 1993; Svenning 2003). Az elterjedési terület feldarabolásával kialakulhatott egy diszjunkt elterjedési terület Eurázsia keleti és nyugati részei között, amelyen azóta a sekély morfológiai különbségekkel a ma létező három faj kialakult. Zhang et al. (2007) a lomboserdei Epimedium fajok Neogén végén vagy Pleisztocén során létrejött eurázsiai diszjunkt elterjedésének kialakulását egy Eurázsián átívelő erdős vegetációnak a klímaváltozások által kiváltott feldarabolódásával magyarázta. Ez egy lehetséges magyarázata lenne a Syringa series Villosae fajok diszjunkt elterjedésének is.

A S. josikaea nagyfokú morfológiai hasonlóságot mutat kelet-ázsiai rokonságával, és ezzel együtt ezektől a fajoktól való elválása nem ítélhető idősnek összehasonlítva a többi ismert divergencia idejű eurázsiai diszjunkt elterjedésű rokonsággal (3. táblázat). Érdekes jelenség, hogy a S. josikaea-hoz hasonlóan a szintén Oleaceae családba tartozó Forsythia europaea elválását keletázsiai rokonaitól a szintén a Pleisztocénre (mintegy 0,5 millió évvel ezelőttre) datálta Kim (1999). Ez a faj a Balkán-félszigeten fordul elő, és a vizsgált taxonok közül filogenetikailag a legközelebb áll a $S$. josikaea-hoz (Wallender és Albert 2000). Azonban éles ellentétben avval, mint amit a Syringa-nál fosszilis maradványok alapján is feltételezhetünk, e szerző a $F$. europaea származását nem egy összefüggő area feldarabolódásával, hanem egy hosszú távú diszperziós eseménnyel magyarázta. 


\subsection{Kismértékü szekvencia variabilitás a Syringa josikaea populációi közt}

A kloroplasztisz genom 13 szakaszát sikerült felszaporítanom és megszekvenálnom, melyek a kloroplasztisz genom változékony szakaszai közül származtak (Shaw et al. 2005, 2007). A kloroplasztisz szekvenciák teljes egyezését találtam a $S$. josikaea elterjedési területének szélső pontjairól származó mintákban a kloroplasztisz genom hosszú - összesen 11135 bp megszekvenált szakaszának ellenére. Más cserje és fa fajokban is ismert a kloroplasztisz genom kismértékü diverzitása vagy teljes uniformitása (Daneck et al. 2011; Worth et al. 2011 és lásd a referenciáikat is), ám a teljes szekvencia azonosság a $S$. josikaea biogeográfiailag szük elterjedési területe valamint kisméretű populációi ellenére is meglepő.

A megszekvenált két nukleáris gén intront korábbi vizsgálatokban filogenetikailag informatívnak találták (Hamman-Khalifa et al. 2007; Li et al. 2008; Calonje et al. 2009), ezzel szemben egyik sem mutatott egyetlen variábilis pozíciót sem.

A riboszomális gének nem kódoló szakaszai, így az ETS és ITS is alacsony evolúciós szinten is variábilisak lehetnek (Baldwin és Markos 1998; Poczai és Hyvönen 2010), és ezek a szakaszok, még ha összesen csupán három bázis pozícióban is, de változékonynak mutatkoztak a S. josikaea különböző mintái között.

Összességében a három nukleotid eltérés 13739 bp-ból egy rendkívül alacsony szekvencia változatosságot takar.

\subsection{A riboszomális lókuszok típusai és leszármazása}

Az összesen három variábilis pozíció négy riboszomális genotípust, úgynevezett ribotípust határozott meg. A ribotípusok minimum-spanning hálózat ábrája szerint csillag alakban egy középen álló ribotípus (a 13. ábrán A-val jelölve) egy-egy mutációs lépésen keresztül kapcsolódik a másik három ribotípushoz (B, C és D), és a központban levő ribotípus áll legközelebbi kapcsolatban a legközelebbi rokon $S$. villosa és $S$. wolfii ribotípusaival.

A parszimónia-elv alapján a $S$. josikaea-ban talált ribotípusok esetében a $S$. josikaea jelenleg létező legősibb típusa a rokon fajokhoz leginkább hasonlító (A) ribotípus, és ebből egy-egy mutációs lépéssel alakult ki a $S$. josikaea három másik ribotípusa (B, C és D). Egy csillag alakú haplotípus hálózat (jelen esetben ribotípus hálózat) olyan evolúciós jelenségre utal, amelyben egy korábban létező, egykor gyakori egyetlen genotípusból alakulhattak ki „fiatal” leszármazott típusok, ezek további mutálódására pedig nem állt még rendelkezésre elegendő idő (O’Corry-Crowe 1997; Cassens et al. 2003; Goropashnaya et al. 2004). A S. josikaea esetében tehát az (A) ribotípus egy 
korábbi palacknyak-effektust egyedüliként túlélt reliktum típus lehet, amelyből később létrejött három új ribotípus. E feltételezett egykori palacknyak-effektust követően a tesztelt kloroplasztisz és nukleáris génekben még nem alakult ki változatosság.

Térben vizsgálva a ribotípusok eloszlását azt tapasztaljuk, hogy az Ukrajnai-Kárpátokban mind a négy, míg az Erdélyi-szigethegységben három ribotípus van jelen. A ribotípusok földrajzi megoszlása mellett azt fontos vizsgálnunk, hogy a $S$. josikaea két diszjunkt areája közül melyikben fordul elő az ősi (A) ribotípus, és esetleg hol vannak jelen csupán leszármazott ribotípusok. Ha találunk ilyen különbséget, választ adhat a kérdésre, hogy a diszjunkt areák kialakulásának melyik kialakulási módja lehet érvényes; tekinthetjük-e az egyiket ősibbnek, amelyből a másik keletkezett akár egyetlen nagy távolságú diszperziós esemény során? Vagy ennek alternatívájaként a két area egy vikarizmust takar-e, és a két area egy egykori közös elterjedési terület maradványának tekinthetö-e?

Az (A) ribotípus mindkét areában jelen van. Ez alapján, és abból következően, hogy mindkét területen találunk több ribotípust is, nem valószínű, hogy valamelyik area a másikból származó propagulumból jött volna létre egy diszperziós esemény során. Valószínűbb, hogy egy egykori közös area maradványaiként kell tekinteni az elterjedési terület két külön részére.

\subsection{Mikroszatellit diverzitás}

\subsubsection{Mikroszatellit markerek tesztelése és fejlesztése}

Csupán csekély hatékonysággal sikerült a $S$. josikaea-ra alkalmazni a rokon fajokra tervezett nukleáris mikroszatellit primereket. Kimerítő optimalizálási kísérletek ellenére a tizenkét tesztelt markerből csak egy olyat sikerült a $S$. josikaea-nál alkalmazni, amely megbízhatóan amplifikálható volt, és az alléljei is konzekvens mintázatot mutattak. A mikroszatellit markerek alacsony átvihetősége nemzetségek között mindazonáltal nem meglepő.

A S. josikaea-ra tervezett primer párok közül három lett megbízhatóan alkalmazható. A három újonnan tervezett valamint az egy Ligustrum ovalifoliumra tervezett mikroszatellit marker is nagy allél és genotípus számmal rendelkeznek, könnyen amplifikálhatóak és kiértékelhetőek.

Két távoli területről származó 20-20 mintán vizsgálva a markereket, semleges evolúciójukat feltételezhetjük; csak az egyik területen egy marker esetében (Syr9) adódott szignifikáns eltérés a Hardy-Weinberg-egyensúlytól, és ezzel együtt itt a beltenyésztési koefficiens is magas volt, ami a heterozigóták lecsökkent számát jelenti. A fajból származó teljes mintán végzett null-allél analízis 
szerint egyes populációkban null-allélek is jelen lehetnek ennél a markernél, amelyek előidézhetik a heterozigóták lecsökkent számát a Hardy-Weinberg egyensúlyban várthoz képest.

A négy marker nagy variabilitásából fakadóan a $S$. josikaea példányok teljes elterjedési területén (a vélhetően egy klónból származó minták összevonását követően) csupán három egymáshoz földrajzilag közeli egyedpárnak lett azonos MLG-a, a többi példány egyedi genetikai jellemzőkkel bírt. A populációhoz rendelési (population assignment) teszt bizonyítja, hogy ezek a markerek a populációk genetikai alapon történő azonosításában is jó hatékonysággal müködnek.

A négy alkalmazott marker az azonos PCR-körülményeinek és a közel átfedő allélhosszaiknak köszönhetően multiplex-PCR-ekhez is alkalmas lehet. Ezek a markerek kiegészíthetők - alkalmazhatóságuk tesztelést követően - a Syringa vulgaris-ra újonnan tervezett mikroszatellitekkel (Juntheikki-Palovaara et al. 2013), melyekkel együtt a jövőben hibrideknél, esetleg rokon fajoknál is alkalmazhatóak lehetnek genetikai vizsgálatokhoz.

\subsubsection{A Syringa josikaea mikroszatellit diverzitása}

A S. josikaea 25 állományából származó 179 minta közül 44-ről állapítottam meg, hogy nagy valószínűséggel egy, a szomszédos minták között már reprezentált példánnyal azonos genetből származik. Ez azt jelenti, hogy, bár a mintagyüjtés egyedenként egy minta gyüjtését célozta, átlagban közel minden harmadik példány egynél többször lett mintázva, mert a szomszédos S. josikaea egyedek közötti határokat nehéz megállapítani. Tehát attól függetlenül, hogy térben nagyobb egy populációnak a kiterjedése, még lehet, hogy csupán néhány klonálisan kiterjedt példány alkotja. Ennek a természetvédelmi jelentősége lehet nagy: egyes populációkat nagyobbnak ítélhetnek, mint amekkorák valójában. Két szélsőséges példa erre az Ukrajnai-Kárpátok két populációja, a 0,15 ha kiterjedésü Kel és 0,5 ha kiterjedésü Roz populációk (Kohut 2013), amelyek csupán két illetve egy genotípust tartalmaztak.

A STRUCTURE analízis eredménye jelentős genetikai elkülönülést mutat az Erdélyiszigethegység és az Ukrajnai-Kárpátok között, amely elkülönülés már két genetikai csoportnál jelentkezik (16. ábra C). Három genetikai csoportnál megjelenik az Erdélyi-szigethegységen belül egy éles genetikai elkülönülés: a meleg-szamosi (Som) populáció gyakorlatilag teljesen az újonnan megjelenő genetikai csoportba kerül, és ez a populáció erre a genetikai csoportra homogén marad a csoportok számát tovább növelve is. A többi populáció közül az Ari és Cne populációk is jelentős mértékben, és a Jad populáció kis mértékben részesülnek ebből a genetikai csoportból. E két genetikai csoport földrajzilag is elkülönül: az egyik a Vlegyásza-hegységre és a Bihar-hegység északi részére jellemző (Seb, Dra, Jad, Gal, Sta populációk), a másik az ezektől keletre fekvő Gyalui-havasokban található meleg-szamosi populációra jellemző. E két genetikai csoport a 
Bihar-hegység déli részén keveredik egymással (Cne, Ari). Feltételezhető a Som populáció hosszú ideje tartó izolációja a Bihar-hegység északi részén és Vlegyásza-hegységben élő populációktól. A genetikai típusoknak a fent vázolt földrajzi elválását jeleníti meg a Barrier analízis. A riboszomális DNS szekvenciákból azonban nem jelent még meg a Som elkülönése, vélhetően az izoláció nem volt kellően hosszú idejü a lassabb mutációs rátájú egyszerü nukleotid polimorfizmusok kialakulásához.

A STRUCTURE eredményeiben a legvalószínübb öt csoportnál a Barrier által kijelölt válaszvonalak közül a legerősebb az Erdélyi-szigethegységen belül van (a 17. ábrán A), csupán a második válaszvonal esik az Erdélyi-szigethegység és az Ukrajnai-Kárpátok közé.

Az Ukrajnai-Kárpátokon belül sokkal kevésbé látható genetikai típusoknak geográfiai struktúrája. A STRUCTURE analízisben két genetikai csoportnál az Ukrajnai-Kárpátokra jellemző genetikai klaszter a csoportszám növelésével tovább bomlik, de ez nem jár földrajzi helyzet szerinti feloszlással. Az adatokra optimálisan illö öt genetikai csoport esetében három genetikai klaszter jellemző az Ukrajnai-Kárpátok populációira. Ezek közül egy (a 16. ábrán zöld) csupán kevesebb egyedre jellemző, ám megjelenik a földrajzilag legtávolabbi Ung-völgyi (Roz és Lut) valamint nagyág-völgyi (Kel) populációkban is. A Latorca vízgyüjtőjében ez a genetikai típus jelentősebben csupán a Vicsa-völgyi Jab populációban fordul elő. A Latorca-völgyi populációkra a másik két genetikai típus jellemző (a 16. ábrán rózsaszín és kék). A Latorca-völgyi állományok közé illik a Kárpátok vízválasztójától Észak-Keletre fekvő egyetlen, Sztrij-völgyi állomány is (Kli). Ez nem meglepő, lévén, hogy a Kli populáció csupán néhány kilométerre fekszik azoktól a populációktól, amelyek a Vereckei-hágó közelében már Kárpátalján, az Ukrajnai-Kárpátok dél-keleti irányba futó lejtőin terülnek el (Lat, Tys, Yal). Ez utóbbiak közül azonban különös a Latorca-menti Tys populáció genetikai besorolása: mind a négy különböző MLG-ú egyedében megjelenik a Bihar és Vlegyásza-hegységekre jellemző genetikai típus, amely egyébként csupán elvétve jelenik meg az ukrajnai mintákban. A Barrier analízis szerint a Tys populáció genetikailag egy önálló szigetet alkot (a 17. ábrán C). E kis populáció néhány kilométeres körzetében elterülö többi populáció (Yal, Lat, Kli) nem tartalmaz genetikailag rendkívüli típusokat. Az erdélyi genetikai típus jelenléte viszont lehetséges, hogy a csupán négy mikroszatellit marker következménye: ilyen kevés markerrel elemzve egy-egy allél is másik genetikai típusba való besorolást eredményezhet, és több marker az Ukrajnai-Kárpátok mintái közé csoportosítaná e mintákat is. A Barrier analízis további negyedik és ötödik válaszvonala az Ukrajnai-Kárpátokban földrajzilag kevéssé magyarázható (D, E), jórészt már csupán jelentéktelenebb populációk közti különbségek mentén alakulnak ki.

Az egy vagy csupán néhány genotípusból álló populációk esetleges elkülönülését nehéz megállapítani a STRUCTURE analízissel, hiszen itt a genetikai csoportok kialakításának feltétele, 
hogy Hardy-Weinberg-egyensúlyra maximalizált csoportok jöjjenek létre, azaz egy vagy csupán néhány egyed, még ha az allélek típusában vagy összetételében különbözik is a környező populációktól, nem fognak önálló csoportokat adni, hanem a létező csoportokhoz lesz hozzárendelve.

A genetikai és geográfiai távolságok korrelációjára végzett Mantel-tesztek a génáramlás limitáltságára utalnak a teljes elterjedési területet és az Erdélyi-szigethegységi areát vizsgálva, míg az Ukrajnai-Kárpátokban a genetikai és geográfiai távolságok közötti korreláció elhanyagolható. Az Erdélyi-szigethegységen belüli erősebb korreláció a STRUCTURE és Barrier analízisek eredményeivel egybevág. Az Ukrajnai-Kárpátokban recens génáramlás a Latorca-völgy egymáshoz küzel eső populációiban feltételezhető, hiszen a néhány kilométeres távolságok a populációk között a megporzó rovarok számára átjárhatók (Zurbuchen et al. 2010). A távolabbi populációk (Kel, Roz, Lut) mintáiban önálló genetikai típusoknak a hiánya, és az egyébütt meglevő csoportok jelenlétének magyarázata lehet esetlegesen jelenlevő, génáramlást biztosító további nem ismert populációk léte, vagy egykor létezett köztes populációk genetikai hatása.

Az Erdélyi-szigethegység mikroszatellit allélszáma és diverzitása magasabb volt, mint az Ukrajnai-Kárpátokban. Ez különösen az Erdélyi-szigethegység jelentősen alacsonyabb mintaszámának fényében meglepő. A $S$. josikaea két elterjedési területének genetikai jellemzői a mikroszatellit-diverzitás alapján jelentően eltérnek, ami mind az ukrajnai, mind a romániai kis méretü populációk megőrzésének fontosságát jelenti.

\subsection{A Syringa josikaea két diszjunkt areajának lehetséges flóratörténeti viszonya}

A mai mérséklelt-övi európai növényzetet alapvetően határozta meg az utólsó eljegesedést követően a lomboserdei-tülevelü vegetáció visszatérése (Hewitt 2000). A hagyományos nézetet, amely szerint az eljegesedéseket a mérsékelt-övi növényzet csupán a dél-európai félszigeteken élte túl, az utóbbi évtized paleobotanikai és genetikai vizsgálatai alapjában kérdőjelezték meg; egyes kutatások a Közép-, sőt Észak-Európában is találtak fás növényzetet még az utolsó eljegesedés idejéből is (Willis et al. 2000, Stewart és Lister 2001; Willis és van Andel 2004; Magri et al. 2006; Provan és Bennett 2008; Parducci et al. 2012). A jégkorszakokat helyben átvészelt populációk jórészt olyan extra-refugiális mikrorefúgiumokban maradtak fenn, ahol a lokális klíma ezt lehetővé tette (Rull 2009).

Az utóbbi évek paleobotanikai eredményei szerint a Nyugati-Kárpátokban az utolsó eljegesedés maximumának idején olyannyira létezett fás vegetáció, hogy az a mai szibériai tajgák növényzetéhez hasonlíthatott (Jankovská és Pokorný 2008; Kuneš et al. 2008). Fosszilis 
maradványok bizonyítják, hogy más fafajok (Picea, Betula) mellett a S. josikaea jellemző élőhelyeinek domináns nemzetsége, az Alnus is fennmaradhatott a Kárpátokban az utolsó jégkorszak legnagyobb lehülései alatt, vélhetően védett, jó vízellátottságú völgyekben (Willis és Van Andel 2004, Feurdean et al. 2007; Ronikier 2011; Stachurska-Swakoń 2012; Douda et al. 2014). A Kárpátokban az utolsó eljegesedés alatt legalább foltokban helyben fennmaradt erdős vegetáció nyomait erdei növényfajok genetikai mintázata is megerősíti (Kramp et al. 2009; Daneck et al. 2011; Slovák et al. 2012).

A mai napig kevés, a Kárpátok különböző területeit részletesen mintázó genetikai vizsgálat született, és a Kárpátokon belül is alulreprezentáltnak számítanak az Ukrajnai-Kárpátok és az Erdélyi-szigethegység területei (Ronikier 2011). A Kárpátok növényfajainak genetikai mintázatát részletesen vizsgáló filogeográfiai tanulmányokban azt mutatták ki, hogy mind magashegyi fajokban (Ehrich et al. 2007; Puşcaş et al. 2008; Ronikier et al. 2008; Thiel-Egenter et al. 2009; Wachowiak et al. 2013), mind szubalpin lágyszárúakban (Mráz et al. 2007; Stachurska-Swakoń et al. 2012) vagy erdei fásszárú fajokban (Gömöry et al. 2004; Heuertz et al. 2004; Fér et al. 2007; Tollefsrud et al. 2008; Höhn et al. 2009; Daneck et al. 2011) az Ukrajnai-Kárpátokban és az Erdélyi-szigethegységben előforduló genetikai típusok is azonosak a Keleti-Kárpátok környező területeinek típusaival. Nem rajzolódik ki tehát a kettő közül egyik területnek a képe sem mint reliktum genotípusokat örző egykori önálló refugiális terület; az Erdélyi-szigethegység és az Ukrajnai-Kárpátok mai növényzete a környező területekről vándorolt be a legutóbbi eljegesedést követően.

Ezzel szemben a $S$. josikaea mikroszatelliteken alapuló genotípusai két eltérő genetikai forrásra utalnak, amelyek külön-külön jellemzőek a két elrejedési területre. Az Ukrajnai-Kárpátok és Erdélyi-szigethegység éles eltérése arra utal, hogy e két terület az utolsó eljegesedés ideje óta vagy egy közös elterjedési terület posztglaciális szétválása óta nem állt genetikai kapcsolatban. A két area különválásának idejére nehéz konkrét becslést adni a mikroszatellit markerekre vonatkozó datálási módszer híján. Valószínütlennek látszik viszont, hogy a S. josikaea az eljegesedést egy déli (Balkán-félszigeten levő) refugiumban vészelte volna át, ahogy az a harmadkori reliktum fajoknál általános (Magri 2010), és azt a hipotézist is elvethetjük, hogy az északabbra fekvő UkrajnaiKárpátok areája a délebbi Erdélyi-szigethegységből származna, utóbbinak az utólsó eljegesedést követő area-expanziója és a közös area posztglaciális szétválásának során.

Az utolsó eljegesedés járt a Pleisztocén eljegesedések közül a legjelentősebb lehüléssel, amely faj ezt helyben túlélte, az vélhetően a korábbi eljegesedések alatt is ugyanezeken a területeken fennmaradhatott (Magri 2010). A ribotípusok megoszlása alapján - több azonos ribotípus, köztük az ősi ribotípus megléte mindkét területen - feltételezhetjük, az Ukrajnai- 
Kárpátok és az Erdélyi-szigethegység $S$. josikaea állományai egy közös areát alkottak, melynek reliktumai a mai elterjedési területek. A kloroplasztisz genomban talált variabilitás hiánya viszont arra enged következtetni, hogy ribotípusok kialakulását megelőzően egy erős palacknyak-hatáson ment keresztül a faj, és erre utal a ribotípusok leszármazási hálózata is.

Összességében a $S$. josikaea-nak egy komplex fajtörténete rajzolódik ki az ázsiai rokonságtól való Kora-Pleisztocén elválással, ezt követő palacknyak-effektussal, majd az Erdélyi-szigethegységet és az Ukrajnai-Kárpátokat is magába foglaló elterjedési terület kialakulásával, végül ennek feldarabolódásával. 


\section{7. Új tudományos eredmények}

1. Aktualizáltam a Syringa josikaea Erdélyi-szigethegységi elterjedését; összesen nyolc állományt találtam, több korábban ismertnek vélt állományról megállapítottam, hogy hibás adat, vagy kihalt populáció. Megállapítottam, hogy a Syringa josikaea populációi az Erdélyi-szigethegységben általánosan kisméretűek, és veszélyeztetettek emberi tevékenységek, elsősorban útépítések és erdészeti munkák kövezkeztében.

2. Molekuláris óra eljárással meghatároztam a Syringa josikaea és legközelebbi rokonai közti divergencia időt, eszerint a Syringa josikaea és Syringa villosa - Syringa wolfii fajok közti elválás ideje 1,88 (0,30-4,04 HPD) millió év. Ez az időszak a Kora Pleisztocén idején a klímaváltozás következtében bekövetkezett kihalási hullámmal hozható összefüggésbe.

3. Megállapítottam, hogy a Syringa josikaea populációi között a DNS szekvenciák variabilitása rendkívül alacsony, amely egy ősi palacknyak-hatás következménye lehet.

4. DNS szekvenciák variabilitása alapján megállapítottam, hogy a Syringa josikaea két diszjunkt areája az Erdélyi-szigethegységben és Ukrajanai-Kárpátokban egy korábban létezett elterjedési terület feldarabolódásával keletkezhetett.

5. Mikroszatellit markereket fejlesztettem ki, amelyek alkalmasak Syringa josikaea populációk populációgenetikai vizsgálatára.

6. Mikroszatellit markerek alapján megállapítottam, hogy az Erdélyi-szigethegységben két földrajzilag elkülönülő genetikai típus létezik, míg az Ukrajnai-Kárpátokban a genetikai típusok nagymértékü keveredése tapasztalható. 


\section{8. Összefoglalás}

A Tercier reliktum fajok széles elterjedési területtel rendelkeztek a Pleisztocén időszakot megelőzően, jelenleg viszont szük refúgium területekre szorítkozik az elterjedésük. A kelet-ázsiai rokonsággal rendelkező Syringa josikaea a Kárpátok endemikus cserjefaja, melynek kisméretü populációi az Erdélyi-szigethegység és az Ukrajnai-Kárpátok diszjunkt területein találhatóak. Pleisztocén és Miocén fosszíliák bizonyítják a $S$. josikaea ősének jelenlétét Közép-Európában, emiatt a $S$. josikaea-t Tercier reliktum fajnak tartják. Az Erdélyi-szigethegységböl a $S$. josikaea előfordulása közel két évszázada ismert, viszont a faj jelenlegi előfordulásai pontatlanul ismertek, ami megakadályozza e törvény által védett faj megfelelő természetvédelmi kezelési stratégiájának létrehozását.

Munkám célja volt, hogy hozzájáruljak a $S$. josikaea aktuális és történeti biogeográfiájának ismeretéhez. Fel szándékoztam tárni a $S$. josikaea pontos elterjedését az Erdélyi-szigethegységben. Tisztázni kívántam a $S$. josikaea történeti biogeográfiáját a $S$. josikaea és legközelebbi ázsiai rokonai közti divergencia idő kiszámításával, és a faj diszjunkt areái közti rokonsági viszonyok felmérésével DNS szekvenciák és nukleáris mikroszatellitek segítségével.

A szakirodalom és herbáriumi példányok áttanulmányozását követően felkerestem a S. josikaea összes jelzett Erdélyi-szigethegységi állományait. Nyolc állományát találtam a fajnak, amelyek közül több is csupán néhány példányból áll. Az elmúlt évtizedekben a populációk mérete lecsökkenhetett, és populációk halhattak ki föképpen erdészeti kezelés és utak építésének következtében. Így az Ukrajnai-Kárpátok 17 populációjával együtt a S. josikaea összesen 25 populációja ismert.

Molekuláris óra analízissel meghatároztam a $S$. josikaea és legközelebbi kelet-ázsiai rokonainak divergencia idejét. Az analízis fosszília-kalibrált Bayesi törzsfán alapult nukleáris riboszomális external és internal transcribed spacer szekvenciákkal. A kalkulált divergencia idő a $S$. josikaea és $S$. villosa - S. wolfii fajok között 1,8 millió évnek adódott (0,30-4,04 millió év HPD), amely más ismert eurázsiai diszjunkciókhoz képest a közös elterjedési területnek egy viszonylag fiatal feldarabolódását jelenti. Ez az időszak a Kora-Pleisztocén kihalásokkal esik egybe, amikor a Tercier fajok jelentős része kihalt Európa mérsékelt övéből.

A fajon belüli DNS szekvenica variabilitást több lókuszban vizsgáltam, köztük tizenhárom kloroplasztisz régiót, két alacsony kópiaszámú nukleáris gént, és a nukleáris riboszomális gének három fragmentumát. Csupán nagyon csekély szekvencia variabilitást találtam a kloroplasztisz régiók teljes egyezésével, amely egy ősi palacknyak-hatást tükröz. A S. josikaea minden 
populációjából vizsgált egyedek riboszomális szekvenciáiban talált összesen három variábilis bázis pozíció nem mutatott jelentős földrajzi elkülönülést, amely Ukrajnai-Kárpátok és az Erdélyi-szigethegység elterjedési területeinek kialakulására egy korábban létezett közös elterjedési terület feloszlását valószínüsíti.

Rokon nemzetségek fajaira tervezett mikroszatellit markerek átvihetőségét teszteltem, és új mikroszatellit markereket fejlesztettem ki a $S$. josikaea-ra egy mikroszatellit-dúsított könyvtár technika alkalmazásával. A négy nagy variabilitású marker lehetővé tette közel az összes vizsgált példány egyedi azonosítását. Bayesi csoportosító eljárással jelentős különbséget találtam az Erdélyiszigethegység és az Ukrajnai-Kárpátok között, amely alapján feltételezhető, hogy az utolsó eljegesedés óta egymástól elszigetelten létezik e két terület. Az Erdélyi-szigethegységben két földrajzilag elkülönülő genetikai csoport van jelen, míg az Ukrajnai-Kárpátok három genetikai csoportja populációkon belül is nagymérétékben keveredett, nagyobb mértékü génáramlásra utalva ezen a területen. Az Erdélyi-szigethegységre és Ukrajnai-Kárpátokra önállóan jellemző genetikai típusok és a két terület jelentős genetikai eltérése felhívja a figyelmet faj megőrzésének fontosságára mind a két elterjedési területen. 


\section{Summary}

Tertiary relict plant species had a large distribution before the Pleistocene but are recently confined to small refugial areas. The eastern Asian related Syringa josikaea is an endemic shrub of temperate forests of the Carpathians, restricted to small populations in disjunct areas of the Apuseni mountains and the Ukrainian Carpathians. Pleistocene and Miocene fossil remains indicate the presence of its ancestors in Central Europe, hence $S$. josikaea has been considered to be a Tertiary relict. Within the Romanian Apuseni mountains $S$. josikaea populations have been known for nearly two centuries, however the species' recent distribution was poorly known impeding the establishment of proper conservation management policies for this legally protected plant species.

My aim was to contribute to the understanding of the current and historical biogeography of S. josikaea. I attempted to elucidate the current distribution of $S$. josikaea in the Apuseni Mountains. I aimed at clarifying the historical biogeography of $S$. josikaea by calculating divergence time between $S$. josikaea and its Asian relatives, and by estimating relation of its two disjunct areas with testing variation of multiple DNA sequences and nuclear microsatellite markers.

Following a thorough examination of the literature and herbarium specimens of $S$. josikaea in the Apuseni mountains, I accomplished a field survey to find remnant populations. The species was found only on eight sites, with several populations comprising only very few individuals. Population sizes may have decreased and populations may have gone extinct predominantly due to forest management and road constructions during the past decades. Hence, together with the seventeen populations known from the Ukrainian Carpathians, S. josikaea is confirmed at altogether twenty-five locations of the Carpathians.

A molecular clock analysis was performed to estimate the divergence time between S. josikaea and the most closely related East Asian species. The analysis was based on a fossil calibrated Bayesian phylogeny using nuclear ribosomal external and internal transcribed spacer sequence data. The divergence time between S. josikaea and the Syringa villosa - Syringa wolfii species was found to be 1.88 million years [0.30-4.04 Mya HPD], suggesting relatively recent disruption of a former common distribution area compared to other Eurasian disjunctions. This time corresponds to the period of Early Pleistocene extinctions, when most Tertiary plant taxa have disappeared from temperate Europe.

Intraspecific DNA sequence variation was assessed at multiple loci including thirteen chloroplast regions, two low-copy nuclear genes and three fragments of the nuclear ribosomal gene. Only very low sequence variability was found among populations of $S$. josikaea - with a complete 
identity in chloroplasts - indicating a possible ancient bottleneck. The altogether three variable base positions found in the ribosomal sequences of the 62 sequenced individuals presented lack of considerable geographic differentiation, implying a vicariance event separating the distribution areas of the Apuseni mountains and the Ukrainian Carpathians.

I tested the transferability of microsatellite primers designed for species of neighboring genera and developed microsatellites for S. josikaea based on a microsatellite enriched library technique. The four highly variable markers held discriminatory power to individually identify nearly all specimens. Bayesian clustering found a pronounced distinction between the Apuseni mountains and the Ukrainian Carpathians, which may be explained by their isolated survival since the last glaciation. Two geographically separated gene pools were recognized in the Apuseni mountains, while higher admixture was found in the Ukrainian Carpathians implying higher gene flow in this area. The unique genetic characteristics of these two areas and their significant differentiation highlight the importance of conserving the small populations in both the Apuseni mountains and the Ukrainian Carpathians. 


\section{Köszönetnyilvánítás}

Köszönettel tartozom témavezetőimnek, Dr. Höhn Mária egyetemi docensnek, a Növénytani Tanszék és Soroksári Botanikus Kert vezetőjének és Dr. Pedryc Andrzej egyetemi tanárnak, a Genetika és Növénynemesítés Tanszék vezetőjének, a messzemenő támogatásért, melyet doktori éveim alatt nyújtottak. Dr. Höhn Máriának külön köszönöm, hogy osztozott velem a terepmunka kihívásaiban.

Benyóné Dr. György Zsuzsanna, Szabadiné Dr. Szikriszt Bernadett és Dr. Gutermuth Ádám nagyon nagy segítséget nyújtottak a laboratóriumi munkák nehezebb pillanataiban, rajtuk kívül a BCE KTK Genetika és Növénynemesítés Tanszék összes munkatársának is ki szeretném fejezni köszönetemet az ötletekért, hasznos tanácsokért, támogatásért.

A terepi munkában és mintagyüjtésben való részvételéért hálás vagyok Dr. Kohut Erzsébetnek (KMF, Beregszász), aki pótolhatatlan segítséget nyújtott az ukrajnai minták begyüjtésében. Rajta kívül a terepi munkában való részvétért köszönettel tartozom Dr. Csergő Annamáriának, Dr. Pócs Tamásnak, Gécse Mátyásnak, Tiponucz Tibornak és Kohut Attilának. Köszönet illeti Öllerer Kingát (BUCA, Bukarest), Dr. Barina Zoltánt, Pifkó Dánielt, Papp Gábort (MTM Növénytár) és Okos-Rigó Ilonát (CL, Kolozsvár), amiért a herbáriumi anyagokat és szakirodalmat a rendelkezésemre bocsájtották. A genetikai vizsgálatokhoz és adatelemzéshez nyújtott nélkülözhetetlen segítségért szeretném köszönetemet kifejezni Prof. Joachim W. Kadereitnek és Dr. Erik Westbergnek (Institut für Spezielle Botanik, Johannes Gutenberg-Universität, Mainz) és Dr. Carolina Cornejonak (Eidgenössische Forschungsanstalt WSL, Birmensdorf). 


\section{Irodalomjegyzék}

Allendorf FW, Luikart G, Aitken SN (2013) Conservation and the genetics of populations. 2nd ed. Wiley-Blackwell, Chichester

Álvarez I, Wendel JF (2003) Ribosomal ITS sequences and plant phylogenetic inference. Molecular Phylogenetics and Evolution 29:417-434

Andreánszky G (1968) Reste d'un lilas du Sarmatien Hongrois. Acta Botanica Academiae Scientiarum Hungaricae 14:1-4

APG III (2009) An update of the Angiosperm Phylogeny Group classification for the orders and families of flowering plants: APG III. Botanical Journal of the Linnean Society 161:105-121 Ardelean A (1999) Flora si Vegetatia din Valea Crisului Alb. Vasile Goldis University Press, Arad

Avise JC (2000) Phylogeography: The history and formation of species. Harward University Press, Cambridge

Baldwin BG, Markos S (1998) Phylogenetic utility of the external transcribed spacer (ETS) of 18S26S rDNA: congruence of ETS and ITS trees of Calycadenia. Molecular Phylogenetics and Evolution 10:449-463

Bartha D (szerk.) (2012) Magyarország ritka fa- és cserjefajainak atlasza. Kossuth Kiadó, Budapest

Baum DA, Small RL, Wendel JF (1998) Biogeography and floral evolution of baobabs (Adansonia, Bombacaceae) as inferred from multiple data sets. Systematic Biology 47:181-207

Beldie A (1979) Flora României. Determinator ilustrat al plantelor vasculare. Edit. Academiei R.S.R., Bucureşti

Besnard G, de Casas RR, Christin P-A, Vargas P (2009) Phylogenetics of Olea (Oleaceae) based on plastid and nuclear ribosomal DNA sequences: Tertiary climatic shifts and lineage differentiation times. Annals of Botany 104:143-160

Bielz EA (1886) Die in Siebenbürgen wildwachsenden Arten der Syringa. Verhandlungen und Mittheilungen des Siebenbürgischen Vereins für Naturwissenschaften 36:51-54

Bilz M (2011) Syringa josikaea. In: IUCN 2011: IUCN Red List of Threatened Species. Version 2011.2. http://www.iucnredlist.org

Blattny T (1910) A Syringa josikaea Jacq. elterjedéséhez. Botanikai közlemények 9:163 
Blattny T (1912a) Megjegyzések Pax „Grundzüge der Pflanzenverbreitung in den Karpathen” (I. és II. kötet) czímű munkájához. Botanikai közlemények 11:185-193

Blattny T (1912b) Újabb adatok a Syringa josikaea elterjedéséhez in: Szakosztályi ügyek. Botanikai közlemények 11:225

Blattny T (1913) Újabb adatok a Syringa josikaea Jacq. fil. elterjedéséhez. Botanikai közlemények $12: 12-14$

Bloor PA, Barker FS, Watts PC, Noyes HA, Kemp SJ (2001) Microsatellite libraries by enrichment, Version 1.0. http://www.genomics.liv.ac.uk/anima1/MICROSAT.PDF

Borbás V (1882) A hazai orgonafa-fajokról. Erdészeti lapok 21:880-887

Borbás V (1887) A Syringa Josikaea Jacqu. fil. magyar földi (endemicus) orgonafa sorsa. Erdészeti lapok 26:251-252

Borza A (1936) Liliacul romansc. Notite dela Grădina Botanica din Cluj 1:1-3

Borza A és Borza V (1939) Flora Stânei de Vale. Buletinul Grădinii Botanice şi al Muzeului Botanic de la Universitatea din Cluj 19:21-54

Burjachs F, Julià R (1994) Abrupt climatic changes during the Last Glaciation based on pollen analysis of the Abric Romaní, Catalonia, Spain. Quaternary Research 42:308-315

Call VB, Dilcher DL (1992) Investigations of angiosperms from the Eocene of southeastern North America: samaras of Fraxinus wilcoxiana Berry. Review of Palaeobotany and Palynology $74: 249-266$

Calleja JA, Benito Garzón M, Sainz Ollero H (2008) A Quaternary perspective on the conservation prospects of the Tertiary relict tree Prunus lusitanica L. Journal of Biogeography $36: 487-498$

Calonje M, Martín-Bravo S, Dobeš C, Gong W, Jordon-Thaden I, Kiefer C, Kiefer M, Paule J, Schmick1 R, Koch MA (2009) Non-coding nuclear DNA marker sin phylogenetic reconstruction. Plant Systematics and Evolution 282:257-280

Carlson SE, Linder HP, Donoghue MJ (2012) The historical biogeography of Scabiosa (Dipsacaceae): implications for Old World plant disjunctions. Journal of Biogeography 39:1086-1100

Cassens I, Van Waerebeek K, Best PB, Crespo EA, Reyes J, Milinkovitch MC (2003) The phylogeography of dusky dolphins (Lagenorhynchus obscurus)? A critical examination of network methods and rooting procedures. Molecular Ecology 12:1781-1792 
Castresana J (2000) Selection of conserved blocks from multiple alignments for their use in phylogenetic analysis. Molecular Biology and Evolution 17:540-552

Chen J-Y, Zhang Z-S, Hong D-Y (2007) A new status and typification of six names in Syringa (Oleaceae). Acta Phytotaxonomica Sinica 45:857-861

Chen J-Y (2008) A Taxonomic Revision of Syringa L. (Oleaceae). Cathaya 17-18:1-118

Chopik VI (1970). Ukrajna ritka növényei. Naukova dumka, Kijev

Ciocarlan V (2009) Flora ilustrata a Romaniei. Pteridophyta et Spermatophyta. Ed. a III-a. Ceres, Bucureşti

Coldea GH (1972) Flora si vegetatia Muntilor Plopis. Teza de doctorat, Universitatea Babes-Bolyai, Cluj-Napoca

Connor SE (2009) Human impact - the last nail in the coffin for ancient plants? Journal of Biogeography 36:485-486

Council of the European Communities (1992) http://eur-lex.europa.eu/LexUriServ/LexUriServ.do? uri=CONSLEG:1992L0043:20070101:EN:PDF

Csapody I (1970) Megemlékezés Blattny Tiborról (1883-1969). Erdészeti lapok 105:221-231 (Az erdő 19:221-231)

Csató J (1886) In: Korrespondenz. Oesterreichische Botanische Zeitschrift 36:249

Csencsics D, Brodbeck S, Holderegger R (2010) Cost-effective, species-specific microsatellite development for the endangered dwarf bulrush (Typha minima) using next-generation sequencing technology. Journal of Heredity 101:789-793

Daneck H, Abraham V, Fér T, Marhold K (2011) Phylogeography of Lonicera nigra in Central Europe inferred from molecular and pollen evidence. Preslia 83:237-257

de la Rosa R, James CM, Tobutt KR (2002) Isolation and characterization of polymorphic microsatellites in olive (Olea europaea L.) and their transferability to other genera in the Oleaceae. Molecular Ecology Notes 2:265-267

Demesure B, Sodzi N, Petit RJ (1995) A set of universal primers for amplification of polymorphic non-coding regions of mitochondrial and chloroplast DNA in plants. Molecular Ecology 4:129-131 
Denk T, Frotzler N, Davitashvili N (2001) Vegetational patterns and distribution of relict taxa in humid temperate forests and wetlands of Georgia (Transcaucasia). Biological Journal of the Linnean Society $72: 287-332$

Dereeper A, Guignon V, Blanc G, Audic S, Buffet S, Chevenet F, Dufayard JF, Guindon S, Lefort V, Lescot M, Claverie JM, Gascuel O (2008) Phylogeny.fr: robust phylogenetic analysis for the non-specialist. Nucleic Acids Research 36(Web Server issue):W465-469

Dewoody J, Nason JD, Hipkins VD (2006) Mitigating scoring errors in microsatellite data from wild populations. Molecular Ecology Resources 6:951-957

Diduch JP (2009) Ukrajna Vörös Könyve. Globalkonszalting, Kijev

Dihoru G, Negrean G (2009) Syringa josikaea. In: Dihoru G és Negrean G (eds.) Cartea rosie a plantelor vasculare din Romania. (Red book of vascular plants of Romania). Academia Romana Institutul de Biologie Bucureşti, Bucureşti

Donoghue MJ, Bell CD, Li J (2001) Phylogenetic patterns in Northern Hemisphere plant geography. International Journal of Plant Sciences 162(Suppl.):S41-S52

Douda J, Doudová J, Drašnarová A, Kuneš P, Hadincová V, Krak K, Zákravský P, Mandák B (2014) Migration patterns of subgenus Alnus in Europe since the Last Glacial Maximum: a systematic review. PLoS ONE 9:e88709

Drummond AJ, Suchard MA, Xie D, Rambaut A (2012) Bayesian phylogenetics with BEAUti and the BEAST 1.7. Molecular Biology and Evolution 29:1969-1973

Earl DA, vonHoldt BM (2012) STRUCTURE HARVESTER: a website and program for visualizing STRUCTURE output and implementing the Evanno method. Conservation Genetics Resources 4:359-361

Ehrich D, Gaudeul M, Assefa A, Koch MA, Mummenhoff K, Nemomissa S, Intrabiodiv Consortium, Brochmann C (2007) Genetic consequences of Pleistocene range shifts: Contrast between the Arctic, the Alps and the East African mountains. Molecular Ecology $16: 2542-2559$

Eickbush TH, Eickbush DG (2007) Finely orchestrated movements: evolution of the ribosomal RNA genes. Genetics 175:477-485

Evanno G, Regnaut S, Goudet J (2005) Detecting the number of clusters of individuals using the software STRUCTURE: a simulation study. Molecular Ecology 14:2611-2620 
Excoffier L, Lischer HEL (2010) Arlequin suite ver 3.5: A new series of programs to perform population genetics analyses under Linux and Windows. Molecular Ecology Resources 10:564-567

Farris JS, Källersjö M, Kluge AG, Bult C (1995) Constructing a significance test for incongruence. Systematic Biology 44:570-572

FBI Laboratory (2013) National DNA Index System (NDIS) Operational Procedures Manual http://www.fbi.gov

Feichtinger S (1871) Krasznamegye és környéke Flórájáról. Mathematikai és természettudományi közlemények. Vonatkozólag a hazai viszonyokra 9:55-115

Fekete L, Blattny T (1913) Az erdészeti jelentőségü fák és cserjék elterjedése a magyar állam területén. Vol 1, Joerges Ágost özv. és fia, Selmecbánya

Fekete L, Blattny T (1914) Die Verbreitung der forstlich wichtigen Bäume und Sträucher im Ungarischen Staate I-II. Joerges Verlag, Schemnitz

Fekete L, Mágocsy-Dietz S (1896) Erdészeti növénytan. Vol 2, Pátria, Budapest

Feng Y, Oh S-H, Manos PS (2005) Phylogeny and historical biogeography of the genus Platanus inferred from nuclear and chloroplast DNA. Systematic Botany 30:786-799

Fér T, Vašák P, Vojta J, Marhold K (2007) Out of the Alps or Carpathians? Origin of Central European populations of Rosa pendulina. Preslia 79:367-376

Feurdean A, Mosbrugger V, Onac BP, Polyak V, Veres D (2007) Younger Dryas to mid-Holocene environmental history of the lowlands of NW Transylvania, Romania. Quaternary Research 68:364-378

Fiala JL (2008) Lilacs: a gardener's encyclopedia. 2nd ed, rev. and updated by Freek Vrgutman. Timber Press, Portland, London

Filipova-Marinova MV, Kvavadze EV, Connor SE, Sjögren P (2010) Estimating absolute pollen productivity for some European Tertiary-relict taxa. Vegetation History and Archaebotany $19: 351-364$

Flatt K (1886) A Syringa josikaea Biharban. Erdészeti lapok 25:141-150

Flatt K (1887) A Syringa josikaea Jacq. fil. faji önállóságáról. Erdészeti lapok 26:568-581 
Flatt K (1890) Briefe über die Syringa Josikaea Jacq. fil. Ein Beitrag zur Geschichte dieser Pflanze.

Verhandlungen und Mittheilungen des Siebenbürgischen Vereins für Naturwissenschaften 40:113-122

Flatt K (1891) A Jósika-fáról (Syringa josikaea Jacq. fil.). Különyomat a Nagyvárad c. napilap 1891. március 29-i számából. Nagyvárad

Fodor I (1974) Kárpátalja flórája. Viscsa Skola Lvivszkoho Universzitetu, Lviv

Folmer O, Black M, Hoeh W, Lutz R, Vrijenhoek R (1994) DNA primers for amplification of mitochondrial cytochrome $c$ oxidase subunit I from diverse metazoan invertebrates. Molecular Marine Biology and Biotechnology 3:294-299

Frankham R, Ballou JD, Briscoe DA (2002) An introduction to conservation genetics. Cambridge University Press, Cambridge

Fuss M (1846) Baumgarten JCG: Enumerationis stirpium Transilvaniae indigenarum Mantissa I. Typis Theodor Steinhaussen, Cibinii

Fuss M (1863) Herbarium Normale Transsilvanicum, Centuria II. Verhandlungen und Mittheilungen des Siebenbürgischen Vereins für Naturwissenschaften 14:188-207

Fuss M (1866) Flora Transsilvaniae excursiora. Typis haeredum Georgii de Closius, Cibinii Gernhard T (2008) The conditioned reconstructed process. Journal of Theoretical Biology 253:769-778

Gilbert KJ, Andrew RL, Bock DG, Franklin MT, Kane NC, Moore J-S, Moyers BT, Renaut S, Rennison DJ, Veen T, Vines T (2012) Recommendations for utilizing and reporting population genetic analyses: the reproducibility of genetic clustering using the program STRUCTURE. Molecular Ecology 21:4925-4930

Gombocz E (1935) A magyar botanika történetéhez. Botanikai közlemények 32:127-130

Gombocz E (1936) A magyar botanika története. Magyar Tudományos Akadémia, Budapest

Goriup P (2008) Natura 2000 in Romania. Species fact list. Manuscript for the Ministry of Environment and Sustainable Development, Bucureşti

Goropashnaya AV, Fedorov VB, Seifert B, Pamilo P (2004) Limited phylogeographycal structure across Eurasia in two red wood ant species Formica pratensis and F. lugubris (Hymenoptera, Formicidae). Molecular Ecology 13:1849-1858 
Gömöry D, Longauer R, Liepelt S, Ballian D, Brus R, Kraigher H, Parpan VI, Parpan TV, Paule L, Stupar VI, Ziegenhagen B (2004) Variation patterns of mitochondrial DNA of Abies alba Mill. in suture zones of postglacial migration in Europe. Acta Societatis Botanicorum Poloniae 73:203-206

Green PS (1972) Osmanthus decorus and disjunct Asiatic-European distributions in the Oleaceae. Kew Bulletin 26:487-490

Guichoux E, Lagache L, Wagner S, Chaumeil P, Léger P, Lepais O, Lepoittevin C, Malausa T, Revardel E, Salin F, Petit RJ (2011) Current trends in microsatellite genotyping. Molecular Ecology Resources 11:591-611

Gulyás A (1906) „Syringa josikaea és S. emodi physiologiai-anatmiai viszonyai, kapcsolatban rendszertani helyzetükkel. In: Jegyzőkönyv az Erdélyi Múzeum-Egyesület Természettudományi szakosztályának 1906. május hó 17-én tartott szakosztályi üléséről. Múzeumi füzetek 1:84

Gulyás A (1907) A Syringa josikaea Jacq. fil. és a Syringa emodi Wallich. Múzeumi füzetek 2:35-65

Gulyás A (1910) A Syringa josikaea Jacqu. fil. és a Syringa emodi Wall. Magyar botanikai lapok 9:284-285

Guo S-Q, Xiong M, Ji C-F, Zhang Z-R, Li D-Z, Zhang Z-Y (2011) Molecular phylogenetic reconstruction of Osmanthus Lour. (Oleaceae) and related genera based on three chloroplast intergenic spacers. Plant Systematics and Evolution 294:57-64

Guo SW, Thompson EA (1992) Performing the exact test of Hardy-Weinberg proportion for multiple alleles. Biometrics 48:361-372

Hamman-Khalifa AM, Navajas-Pérez R, de la Herrán R, Ruiz Rejón M, Garrido-Ramos A, Ruiz Rejón C, Rosúa JL (2007) Establishing the genetic relationships between the wild and cultivated olives using a nuclear intron from nitrate reductase (nia-i3). Plant Systematics and Evolution 269:63-73

Harrison TM, Copeland P, Kidd WSF, Yin A (1992) Raising Tibet. Science 255:1663-1670

Heuertz M, Fineschi S, Anzidei M, Pastorelli R, Salvini D, Paule L, Frascaria-Lacoste N, Hardy OJ, Vekemans X, Vendramin GG (2004) Chloroplast DNA variation and postglacial recolonization of common ash (Fraxinus excelsior L.) in Europe. Molecular Ecology $13: 3437-3452$ 
Hewitt (2000) The genetic legacy of the Quaternary ice ages. Nature 405:907-913

Hinsinger DD (2010) Diversité et évolution du genre Fraxinus. PhD thése, Universite Laval, Québec

Hong-Wa C, Besnard G (2013) Intricate patterns of phylogenetic relationships in the olive family as inferred from multi-locus plastid and nuclear DNA sequence analyses: A close-up on Chionanthus and Noronhia (Oleaceae). Molecular Phylogenetics and Evolution 67:367-378

Höhn M, Gugerli F, Ábrán P, Bisztray G, Buonamici A, Cseke K, Hufnagel L, Quintela-Sabarís C, Sebastiani F, Vendramin GG (2009) Variation in the chloroplast DNA of Swiss stone pine (Pinus cembra L.) reflects contrasting post-glacial history of populations from the Carpathians and the Alps. Journal of Biogeography 36:1798-1806

Hubisz MJ, Falush D, Stephens M, Pritchard JK (2009) Inferring weak population structure with the assistance of sample group information. Molecular Ecology Resources 9:1322-1332

Huntley B (1993) Species-richness in the north-temperate zone forests. Journal of Biogeography $20: 163-180$

International Commission on Stratigraphy (2013) International Chronostratigraphic Chart v2013/01. http://www.stratigraphy.org

Ioras F, Abrudan IV (2006) The Romanian forestry sector: privatisation facts. International Forestry Review 8:361-367

Jacquin J (1831a) Syringa josikaea. In: Botanische Verhandlungen bei der Versammlung der Naturforscher und Aerzte zu Hamburg im Jahr 1830. Flora oder allgemeine botanische Zeitung 1:67

Jacquin J (1831b) Kürzere bemerkungen. Flora oder allgemeine botanische Zeitung 14:399-400

Jakobsson M, Rosenberg NA (2007) CLUMPP: a cluster matching and permutation program for dealing with label switching and multimodality in analysis of population structure. Bioinformatics 23:1801-1806

Janka V (1854) In: Korrespondenz. Oesterrieichische Botanische Wochenblatt 4:188

Janka V (1884) Megjegyzés a Syringa josikaea leírásának keltéhez. Természetrajzi füzetek $8: 313-314$

Janka V (1885) Erste Quelle der S. josikaea die PL. Crit. Reichenbach's. Botanisches centralblatt $6: 148$ 
Jankovská V, Pokorný P (2008) Forest vegetation of the last full-glacial period in the Western

Carpathians (Slovakia and Czech Republic). Preslia 80:307-324

Járai-Komlódi M (1990) Pollen-statistical analyses from the Vértesszőlős travertine. In: Kretzoi M,

Dobosi TV (eds.) Vértesszőlős, site, man and culture. Akadémiai Kiadó, Budapest 125-135

Járai-Komlódi M (2000) A Kárpát-medence növényzetének kialakulása. Tilia 9:5-59

Jávorka S (1925) Magyar Flóra. Magyarország virágos és edényes virágtalan növényeinek meghatározó kézikönyve. Vol II. Studium, Budapest

Juntheikki-Palovaara I, Antomius K, Lindén L, Korpoleinen H (2013) Microsatellites for common lilac (Syringa vulgaris L.). Plant Genetic Resources 11:279-282

Kanitz Á (1887) Observations sur les Syringa du nord de la Chine. Par M. A. Franchet in: Könyvismertetések. Magyar növénytani lapok 11:23-27

Kim K-J (1998) A new species of Fontanesia (Oleaceae) from China and taxonomic revision of the genus. Journal of Plant Biology 41:142-145

Kim K-J (1999) Molecular phylogeny of Forsythia (Oleaceae) based on chloroplast DNA variation. Plant Systematics and Evolution 218:113-123

Kim K-J, Jansen RK (1998) A chloroplast DNA phylogeny of lilacs (Syringa, Oleaceae): plastome groups show a strong correlation with crossing groups. American Journal of Botany $85: 1338-1351$

Kocher TD, Thomas WK, Meyer A, Edwards SV, Pääbo S, Villablanca FX, Wilson AC (1989) Dynamics of mitochondrial DNA evolution in animals: Amplification and sequencing with conserved primers. Proceedings of the National Academy of Sciences of the USA $86: 6196-6200$

Kochieva EZ, Ryzhova NN, Molkanova OI, Kudryavtsev AM, Upelniek VP, Okuneva IB (2004) The genus Syringa: molecular markers of species and cultivars. Russian Journal of Genetics $40: 30-32$

Kodama K, Yamada T, Maki M (2008) Development and characterization of 10 microsatellite markers for the semi-evergreen tree species, Ligustrum ovalifolium (Oleaceae). Molecular Ecology Resources 8:1008-1010

Kohut E (2013) A Syringa josikaea Jacq. fil. ex Rchb. és a Leucojum aestivum L. kárpátaljai természetes állományainak felmérése és in vitro szaporítása. $\mathrm{PhD}$ értekezés, Budapesti Corvinus Egyetem, Budapest 
Kohut E, Höhn M (2010) A Jósika orgona (Syringa josikaea Jacq. fil.) termőhelyi viszonyai Kárpátalján. Acta Beregsasiensis 10:55-67

Kramp K, Huck S, Niketić M, Tomović G, Schmitt T (2009) Multiple glacial refugia and complex postglacial range shifts of the obligatory woodland plant Polygonatum verticillatum (Convallariaceae). Plant Biology 11:392-404

Kuneš P, Pelánková B, Chytrý M, Jankovská V, Pokorný P, Petr L (2008) Interpretation of the lastglacial vegetation of eastern-central Europe using modern analogues from southern Siberia. Journal of Biogeography 35:2223-2236

Landoz J (1844) Névsora a’ Kolozsvár környékén termő növényeknek, mellyeket több évi vizsgálódásai után összegyüjtött 's a' magyar orvosok és természetvizsgálók 1844-dik év szeptember 2-kán Kolozsvártt tartott nagy gyülésének bémutatott. Ifj. Tilsch János, Kolozsvár

Landoz J (1861-1863) A kolozsvári és szomszéd határokon termő növények névsora. Az Erdélyi Múzeum-Egyesület évkönyvei 2:26-40

Leberg PL (2002) Estimating allelic richness: Effects of sample size and bottlenecks. Molecular Ecology 11:2445-2449

Lemey P, Posada D (2010) Molecular clock anaylsis. In: Lemey P., Salemi M, Vandamme A-M (eds.): The phylogenetic handbook. 2nd ed., Cambridge University Press, Cambridge $362-380$

Lendvay B, Kohut E, Höhn M (2012) A Jósika-orgona - Syringa josikaea Jacq. fil. ex Rchb. történeti és aktuális előfordulása, a populációk élőhelyi és természetvédelmi jellemzése. Kanitzia 19:27-58

Lendvay B, Pedryc A, Höhn M (2013) Characterization of nuclear microsatellite markers for the narrow endemic Syringa josikaea Jacq. fil. ex Rchb. Notulae Botanicae Horti Agrobotanici Cluj-Napoca 41:301-305

Li J, Alexander JH, Zhang D (2002) Paraphyletic Syringa (Oleaceae): Evidence from sequences of nuclear ribosomal DNA ITS and ETS regions. Systematic Botany 27:592-597

Li J, Goldman-Huertas B, DeJong J, Alexander J III (2012) Phylogenetics and diversification of Syringa inferred from nuclear and plastid DNA sequences. Castanea 77:82-88 
Li J, Zhang D, Alexander JH (2001) Classification of tree lilacs (subgenus Ligustrina, Syringa, Oleaceae): morphology and DNA sequence tell a similar story. Harvard Papers in Botany $5: 517-529$

Li M, Wunder J, Bissoli G, Scarponi E, Gazzani S, Barbaro E, Saedler H, Varotto C (2008) Development of COS genes as universally amplifiable markers for phylogenetic reconstructions of closely related plant species. Cladistics 24:727-745

Lian C, Wadud A, Geng Q, Shimatani K, Hogetsu T (2006) An improved technique for isolating codominant compound microsatellite markers. Journal of Plant Research 119:415-417

Liu Y, Cui H, Zhang Q, Sodmergen (2004) Divergent potentials for cytoplasmatic inheritance within the genus Syringa. A new trait associated with speciogenesis. Plant Physiology $136: 2762-2770$

Maggini F, Gelati MT, Spolverini M, Frediani M (2008) The intergenic spacer region of the rDNA in Olea europaea L. Tree Genetics and Genomes 4:293-298

Magri D (2010) Persistence of tree taxa in Europe and the Quaternary climate changes. Quaternary International 219:145-151

Magri D, Vendramin GG Comps B, Dupanloup I, Geburek T, Gömöry D, Latałowa M, Litt T, Paule L, Roure JM, Tantau I, Van Der Knaap WO, Petit RJ, De Beaulieu J-L (2006) A new scenario for the Quaternary history of European beech populations: palaeobotanical evidence and genetic consequences. New Phytologist 171:199-221

Mai DM (1989) Development and regional differentiation of the European vegetation during the Tertiary. Plant Systematics and Evolution 162:79-91

Mania D (2006) Stratigraphie, Klima- und Umweltentwicklung der letzten 400000 Jahre im Saalgebiet und Harzvorland (Forschungsstand 2006). Hercynia 39:155-194

Mania D, Mania U (2008) La stratigraphie et le Paléolithique du complexe saalien dans la région de la Saale et de l'Elbe Stratigraphy and Paleolithic of the Saale complex in the Elbe-Saale region. L'anthropologie 112:15-47

Manni F, Guérard E, Heyer E (2004) Geographic patterns of (genetic, morphologic, linguistic) variation: how barriers can be detected by "Monmonier's algorithm”. Human Biology $76: 173-190$

Mantel N (1967) The detection of disease clustering and a generalized regression approach. Cancer Research 27:209-220 
Marsolais JV, Pringle JS, White BN (1993) Assessment of random amplified polymorphic DNA (RAPD) as genetic markers for determining the origin of interspecific lilac hybrids. Taxon 42:531-537

McKelvey SD (1928) The lilac: a monograph. Macmillan, New York

Melnikova NV, Borhert EV, Martynov SP, Okuneva IB, Molkanova OI, Upelniek VP, Kudryavtsev AM (2009) Molecular genetic marker-based approaches to the verification of lilac Syringa vulgaris L. in vitro germplasm collections. Russian Journal of Genetics 45:85-90

Michalus S (1887) A Syringa josikaea előjöveteléről. Erdészeti lapok 26:982-983

Michalus S (1898) Pinus silvestris és Syringa josikaea in: Különfélék. Erdészeti lapok 37:847-849

Milne RI (2006) Northern Hemisphere plant disjunctions: a window on Tertiary land bridges and climate change? Annals of Botany 98:465-472

Milne RI, Abbott RJ (2002) The origin and evolution of tertiary relict floras. Advances in Botanical Research 38:281-314

Molnár V A (1999) Bevezetés Magyarország florisztikai növényföldrajzába. In: Farkas S (szerk.): Magyarország védett növényei. Mezőgazda Kiadó, Budapest

Molnár V A (2006) A báróné orgonája. In: Újhelyi $\mathrm{P}$ és Molnár V A (szerk.): Élővilág enciklopédia. A Kárpát-medence gombái és növényei. Kossuth Kiadó, Budapest

Morariu I (1961) Oleaceae. In: Savulescu T. (red.): Flora Republicii Populare Romane vol. VIII. Edit., Editura Academiei Republicii Populare Romine, Bucureşti

Mráz P, Gaudeul M, Rioux D, Gielly L, Choler P, Taberlet P, IntraBioDiv Consortium (2007) Genetic structure of Hypochaeris uniflora (Asteraceae) suggests vicariance in the Carpathians and rapid post-glacial colonization of the Alps from an eastern Alpine refugium. Journal of Biogeography 34:2100-2114

O’Corry-Crowe GM, Suydam RS, Rosenberg A, Frost KJ, Dizon AE (1997) Phylogeography, population structure and dispersal patterns of the beluga whale Delphinapterus leucas in the western Nearctic revealed by mitochondrial DNA. Molecular Ecology 6:955-970

Paetkau D, Calvert W, Stirling I, Strobeck C (1995) Microsatellite analysis of population structure in canadian polar bears. Molecular Ecology 4:347-354

Parducci L, Jørgensen T, Tollefsrud MM, Elverland E, Alm T, Fontana SL, Bennett KD, Haile J, Matetovici I, Suyama Y, Edwards ME, Andersen K, Rasmussen M, Boessenkool S, Coissac E, Brochmann C, Taberlet P, Houmark-Nielsen M, Krog Larsen N, Orlando L, Gilbert MTP, 
Kjær KH, Greve Alsos I, Willerslev E (2012) Glacial survival of boreal trees in northern Scandinavia. Science 335:1083-1086

Parks JC, Werth CR (1993) A study of spatial features of clones in a population of bracken fern, Pteridium aquilinum (Dennstaedtiaceae). American Journal of Botany 80:537-544

Pax F (1898) Grundzüge der Pflanzenverbreitung in der Karpathen I. W Engelmann, Leipzig

Peakall R, Smouse PE (2012) GenAlEx 6.5: genetic analysis in Excel. Population genetic software for teaching and research-an update. Bioinformatics 28:2537-2539

Péterfi M (1918) A Syringa josikaea Jacq. fil. „Bujfunu” termőhelyéről in: Apró közlemények. Magyar botanikai lapok 17:97-98

Petit RJ, El Mousadik A, Pons O (1998) Identifying populations for conservation on the basis of genetic markers. Conservation Biology 12:844-855

Poczai P, Hyvönen J (2010) Nuclear ribosomal spacer regions in plant phylognetics: problems and prospects. Molecular Biology Reporter 37:1897-1912

Podani J (2001) SYN-TAX 2000. Computer programs for data analysis in ecology and systematics. User's manual. Scientia, Budapest

Posada D (2008) JModelTest: phylogenetic model averaging. Molecular Biology and Evolution $25: 1253-1256$

Postigo-Mijarra JM, Morla C, Barrón E, Morales-Molino C, García S (2010) Patterns of extinction and presence of Arctotertiary flora in Iberia during the Quaternary. Review of Paleobotany and Palynology 162:416-426

Powell W, Machray GC, Provan J (1996) Polymorphism revealed by simple sequence repeats. Trends in Plant Sciences 1:215-222

Prodan I (1939) Flora pentru determinarea şi descrierea plantelor ce cresc în România, Ed 2, Vol 1, Tipografia“"Cartea Românească”, Cluj-Napoca

Provan J, Bennett KD (2008) Phylogeographic insights into cryptic glacial refugia. Trends in Ecology and Evolution 23:564-571

Puşcaş M, Choler P, Tribsch A, Gielly L, Rioux D, Gaudeul M, Taberlet P (2008) Post-glacial history of the dominant alpine sedge Carex cuvula in the European Alpine System inferred from nuclear and chloroplast markers. Molecular Ecology 17:2417-2429 
Radnóti D (1888) Régi magyar megfigyelések. 60. (Syringa josikaea). Természettudományi közlöny 20:202

Rambaut A (2012) FigTree v1.4. http://www.tree.bio.ed.ac.uk/software/figtree

Rambaut A, Drummond A (2009) Tracer v1.5. http://www.beast.bio.ed.ac.uk/Tracer

Raţiu O, Gergely I, Şuteu ŞT (1984) Flora şi Unitatile fitosintaxonomice de pe Valea Iadului (Jud. Bihor). Importanta economica şi stiintifica. Caracterizarea lor ecologica III. Contribuţii Botanice 24:85-135

Raven PH (1972) Plant species disjunctions: a summary. Annals of the Missouri Botanical Garden 59:234-246

Rehder A (1945) Notes on some cultivated trees and shrubs. Journal of the Arnold Arboretum 26:67-78

Reichenbach L (1830-1832) Syringa josikaea. No. 2867. Flora germanica excursoria ex affinitate regni vegetabilis naturali disposita, sive principia synopseos plantarum in Germania terrisque in Europa media adjacentibus sponte nascentium cultarumque frequentius. Carolum Cnobloch, Lipsiae

Renner SS (2005) Relaxed molecular clocks for dating historical plant dispersal events. Trends in Plant Sciences 10:550-558

Resmeriţă, I (1970) Flora, vegetaţia şi potenţialul productiv pe masivul Vlădeasa, Editura Academiei Republicii Populare Romine, Bucureşti

Ronikier M (2011) Biogeography of high-mountain plants in the Carpathians: An emerging phylogeographical perspective. Taxon 60:373-389

Ronikier M, Cieślak E, Korbecka G (2008) High genetic differentiation in the alpine plant Campanula alpina Jacq. (Campanulaceae): evidence for glacial survival in several Carpathian regions and long-term isolation between the Carpathians and the Alps. Molecular Ecology 17:1763-1775

Rull V (2009) Microrefugia. Journal of Biogeography 36:481-484

Rzepka-Plevneš D, Smolik M, Tańska K (2006) Genetic similarity of chosen Syringa species determined by the ISSR-PCR technique. Dendrobiology 56:61-67

Salzmann U, Haywood AM, Lunt DJ, Valdes Pj, Hill DJ (2008) A new global biome reconstruction and data-model comparison for the Middle Pliocene. Global Ecology and Biogeography $17: 432-447$ 
Sang T, Crawford DJ, Stuessy TF (1997) Chloroplast DNA phylogeny, reticulate evolution, and biogeography of Paeonia (Paeoniaceae). American Journal of Botany 84:1120-1136

Sargent CS (1888) Notes upon lilacs. Garden and Forest 1:220-222

Schäferhoff B, Fleischmann A, Fischer E, Albach DC, Borsch T, Heubl G, Müller KF (2010) Towards resolving Lamiales relationships: insights from rapidly evolving chloroplast sequences. BMC Evolutionary Biology 10:352

Schoebel CN, Brodbeck S, Buehler D, Cornejo C, Gajurel J, Hartikainen H, Keller D, Leys M, Říčanová Š, Segelbacher G, Werth S, Csencsics D (2013) Lessons learned from microsatellite development for nonmodel organisms using 454 pyrosequencing. Journal of Evolutionary Biology 26:600-611

Schuelke M (2000) An economic method for the fluorescent labeling of PCR fragments. Nature Biotechnology 18:233-234

Schur PJF (1866) Enumeratio plantarum Transsilvaniae exhiben: stirpes phanerogamas sponte crescentes atque frequentius cultas, cryptogamas vasculares, charceas, etiam muscos hepaticasque. Guilielmum Braumüller, Vindobonae

Shaw J, Lickey EB, Beck JT, Farmer SB, Liu W, Miller J, Siripun KC, Winder CT, Schilling EE, Small RL (2005) The tortoise and the hare II: relative utility of 21 noncoding chloroplast DNA sequences for phylogenetic analysis. American Journal of Botany 92:142-166

Shaw J, Lickey EB, Schilling EE, Small RL (2007) Comparison of whole chloroplast genome sequences to choose noncoding regions for phylogenetic studies in angiosperms: the tortoise and the hare III. American Journal of Botany 94:275-288

Simonkai L (1881) Kirándulásaim a Bihar- és az Iskola-egységekben. Természetrajzi füzetek $5: 43-46$

Simonkai L (1886) Erdély edényes flórájának helyesbített foglalata. Királyi Magyar Természettudományi Társulat, Budapest

Simonkai L (1890) Nagyváradnak és vidékének növényvilága. In: Bunyitay V (szerk.): Nagyvárad természetrajza. Magyar Orvosok és Természetvizsgálók, Budapest 72-77

Skoflek I (1968) Quarternäre Syringa-Arten von Vértesszőlős und Mónosbél. Acta Botanica Academiae Scientiarum Hungaricae 14:133-145

Skoflek I (1990) Plant remains from the Vértesszőlős travertine. In: Kretzoi M, Dobosi TV (eds.) Vértesszőlős, site, man and culture. Akadémiai Kiadó, Budapest 77-123 
Slovák M, Kučera J, Turis P, Zozomová-Lihová J (2012) Multiple glacial refugia and postglacial colonization routes inferred for a woodland geophyte, Cyclamen purpurascens: patterns concordant with the Pleistocene history of broadleaved and coniferous tree species. Biological Journal of the Linnean Society 105:741-760

Small RL, Ryburn JA, Cronn RC, Seelanan T, Wendel JF (1998) The tortoise and the hare: choosing between noncoding plastome and nuclear Adh sequences for phylogenetic reconstruction in a recently diverged plant group. American Journal of Botany $85: 1301-1315$

Soó R (1944a) A Sebesvölgy növényzetéről. (A Jósika-orgona „locus classicusán”.). Scripta Botanica Musei Transsilvanici 3:56-61

Soó R (1944b) A Jádvölgy növényzetéről. Scripta Botanica Musei Transsilvanici 3:62-74

Squirrell J, Hollingsworth M, Woodhead M, Russell J, Lowe AJ, Gibby M, Powell W (2003) How much effort is required to isolate nuclear microsatellites from plants? Molecular Ecology 12:1339-1348

Stachurska-Swakoń A, Cieślak E, Ronikier M (2012) Phylogeography of subalpine tall-herb species in Central Europe: the case of Cicerbita alpina. Preslia 84:121-140

Stefan E (1971) Syringa josikaea Jacq. in vestul tarii. Comunicari de Botanica 12:279-284

Steudel EG (1840-1841) Nomenclatur botanicus seu, Synonymia plantarum universalis: enumerans ordine alphabetico nomina atque synonyma, tum generica tum specifica, et a Linnaeo et a recentioribus de re botanica scriptoribus plantis phanerogamis imposita. Vol 2, Stuttgart, Tübingen

Stewart JR, Lister AM (2001) Cryptic northern refugia and origins of the modern biota. Trends in Ecology and Evolution 16:608-613

Suzuki M, Watari S (1994) Fossil wood flora of the Early Miocene Nawamata formation of Monze, Noto Peninsula, Central Japan. Journal of Plant Research 107:63-76

Svenning J-C (2003) Deterministic Plio-Pleistocene extinctions in the European cool-temperate tree flora. Ecology Letters 6:646-653

Swofford DL (2002) PAUP*: Phylogenetic Analysis Using Parsimony. (*and Other Methods), Version 4.0b10. Sinsauer Associates, MA, USA

Taberlet P, Gielly L, Pautou G, Bouvet J (1991) Universal primers for amplification of three noncoding regions of chloroplast DNA. Plant Molecular Biology 17:1105-1109 
Tamura K, Nei M (1993) Estimation of the number of nucleotide substitutions in the control region of mitochondrial DNA in humans and chimpanzees. Molecular Biology and Evolution $10: 512-526$

Tamura K, Peterson D, Peterson N, Stecher G, Nei M, Kumar S (2011) MEGA5: Molecular evolutionary genetics analysis using maximum likelihood, evolutionary distance, and maximum parsimony methods. Molecular Biology and Evolution 28:2731-2739

Tasenkevitch L (2003) Vascular Plants. In: Witkowki ZJ (ed.) Carpathian List of Endangered Species. Vienna, Krakow http://www.carpates.org

Teacher AGF, Griffiths DJ (2011) HapStar: automated haplotype network layout and visualization. Molecular Ecology Resources 11:151-153

Thaisz L (1909a) A Syringa josikaea mint növénygeográfiai útmutató in: Szakosztályi ügyek. Botanikai közlemények 8:57

Thaisz L (1909b) A Syringa josikaea Jacq. fil. mint növénygeográfiai útmutató. Magyar botanikai lapok 8:217-221

Thaisz L (1912) A Syringa josikaea Jacq. fil. újabb termühelyei. Magyar botanikai lapok $11: 236-237$

Thiel-Egenter C, Holderegger R, Brodbeck S, Intrabiodiv Consortium, Gugerli F (2009)

Concordant genetic breaks, identified by combining clustering and tessellation methods, in two co-distributed alpine plant species. Molecular Ecology 18:4495-4507

Thompson RS, Fleming RF (1996) Middle Pliocene vegetation: reconstructions, plaeoclimatic inferences, and boundary conditions for climate modeling. Marine Micropaleontology $27: 27-49$

Thorne RF (1972) Disjunctions in the geographic ranges of seed plants. The Quarterly Review of Biology 47:365-411

Tiffney BH, Manchester SR (2001) The use of geological and paleontological evidence in evaluating plant phylogeographic hypotheses in the Northern Hemisphere Tertiary. International Journal of Plant Sciences 162(Suppl.):3-17

Tollefsrud MM, Kissling R, Gugerli F, Johnsen Ø, Skrøppa T, Cheddadi R, Van Der Knaap WO, Latałowa M, Terhürne-Berson R, Litt T, Geburek T, Brochmann C, Sperisen C (2008) Genetic consequences of glacial survival and postglacial colonization in Norway spruce: 
combined analysis of mithocondrial DNA and fossil pollen. Molecular Ecology $17: 4134-4150$

Tu T, Volis S, Dillon MO, Sun H, Wen J (2010) Dispersals of Hyoscyameae and Mandragoreae (Solanaceae) from the New World to Eurasia in the early Miocene and their biogeographic diversification within Eurasia. Molecular Phylogenetics and Evolution 57:1226-1237

Valtueña FJ, Preston CD, Kadereit JW (2012) Phylogeography of a Tertiary relict plant, Meconopsis cambrica (Papaveraceae), implies the existence of northern refugia for a temperate herb. Molecular Ecology 21:1423-1437

Van Oosterhout C, Hutchinson WF, Willis DP, Shipley P (2004) MICRO-CHECKER: software for identifying and correcting genotyping errors in microsatellite data. Molecular Ecology Notes $4: 535-538$

Vent W (1955) Über die Flora des Riss-Würm-Interglazials in Mitteldeutschland unter besonderer Berücksichtung der Ilmtravertine von Weimar-Ehringsdorf. Wissenschaftliche Zeitschrift der Friedrich-Schiller-Universität, Jena 55:467-485

Voronoï MG (1908) Nouvelles application des paramètres continus à la théorie des formes quadratiques. Deuxième mémoire. Recherche sur le paralléloedres primitifs. Journal für die reine und angewandte Mathematik 134:198-207

Wachowiak W, Boratyńska K, Cavers S (2013) Geographical patterns of nucleotide diversity and population differentiation in three closely related European pine species in the Pinus mugo complex. Botanical Journal of the Linnean Society 172:225-238

Wallander E, Albert VA (2000) Phylogeny and classification of Oleaceae based on rps16 and trnL-F sequence data. American Journal of Botany 87:1827-1841

Wang J, Wang YJ, Liu ZC, Li JQ, Xi P (1999) Cenozoic environmental evolution of the Qaidam Basin and its implications for the uplift of the Tibetan Plateau and the drying of central Asia. Palaeogeography, Palaeoclimatology, Palaeoecology 152:37-47

Wen J (1999) Evolution of Eastern Asian and Eastern North American disjunct distributions in flowering plants. Annual Review of Ecology, Evolution and Systematics 30:421-455

White TJ, Bruns TD, Lee S, Taylor J (1990) Analysis of phylogenetic relationships by amplification and direct sequencing of ribosomal RNA genes. In: Innis MA, Gelfand DH, Sninsky JJ, White TJ (eds.) PCR Protocols: a Guide to Methods and Applications. Academic Press, New York 315-322 
Willis KJ, McElwain JC (2002) The evolution of plants. Oxford University Press, Oxford

Willis KJ, Niklas KJ (2004) The role of Quaternary environmental change in plant macroevolution: the exception or the rule? Philosophical Transactions of the Royal Society B 359:159-172

Willis KJ, Rudner E, Sümegi P (2000) The full-glacial forests of central and southeastern Europe. Quaternary Research 53:203-213

Willis KJ, Van Andel TH (2004) Trees or no trees? The environments of central and eastern Europe during the Last Glaciation. Quaternary Science Reviews 23:2369-2387

Wood CE Jr (1972) Morphology and phytogeography: the classical approach to the study of disjunctions. Annals of the Missouri Botanical Garden 59:107-124

Worth JRP, Marthick JR, Jordan GJ, Vaillancourt RE (2011) Low but structured chloroplast diversity in Atherosperma moschatum (Atherospermataceae) suggests bottlenecks in response to the Pleistocene glacials. Annals of Botany 108:1247-1256

Xiang Q-Y Soltis DE (2001) Dispersal-Vicariance analyses of intercontinental disjunctions: historical biogeographical implications for Angiosperms in the Northern Hemisphere. International Journal of Plant Sciences 162(Suppl.):29-39

Xiang Q-Y, Crawford DJ, Wolfe AD, Tang Y-C, DePamphilis CW (1998) Origin and biogeography of Aesculus L. (Hippocastanaceae): a molecular phylogenetic perspective. Evolution 54:988-997

Xiang Q-Y, Manchester SR, Thomas DT, Zhang W, Fan C (2005) Phylogeny, biogeography, and molecular dating of cornelian cherries (Cornus, Cornaceae): tracking tertiary plant migration. Evolution 59:1685-1700

Xinlu C, Zhenfeng C, Jing H (1999) Using random amplified polymorphic DNA (RAPD) markers for lilac genetic analysis and classification in lilac cultivars. Acta Botanica Boreali-Occidentalia Sinica 19:169-176

Yokohama J, Suzuki M, Iwatsuki K, Hasebe M (2000) Molecular phylogeny of Coriaria, with special emphasis on the disjunct distributions. Molecular Phylogenetics and Evolution 14:11-19

Zachos J, Pagani M, Sloan L, Thomas E, Billups K (2001) Trends, rythms, and aberrations in global climate 65 Ma to present. Science 292:686-693

Zane L, Bargelloni L, Patarnello T (2002) Strategies for microsatellite isolation: a review. Molecular Ecology 11:1-16 
Zhang M-L, Uhink CH, Kadereit JW (2007) Phylogeny and biogeography of

Epimedium/Vancouveria (Berberidaceae): Western North American - East Asian disjunctions, the origin of European muntain plant taxa, and East Asian species diversity. Systematic Botany 32:81-92

Zhang Z, Fan L, Yang J, Hao X, Gu Z (2006) Alkaloid polymorphism and ITS sequence variation in the Spiraea japonica complex (Rosaceae) in China: traces of the biological effects of the Himalaya-Tibet Plateau uplift. American Journal of Botany 93:762-769

Zhisheng A, Kutzbach JE, Prell WL, Porter SC (2001) Evolution of Asian monsoons and phased uplift of the Himalaya-Tibetian plateau since the Late Miocene times. Nature 411:62-66

Zurbuchen A, Landert L, Klaiber J, Müller A, Hein S, Dorn S (2010) Maximum foraging ranges in solitary bees: only few individuals have the capability to cover long foraging distances. Biological Conservation 143:669-676 


\section{Függelék}

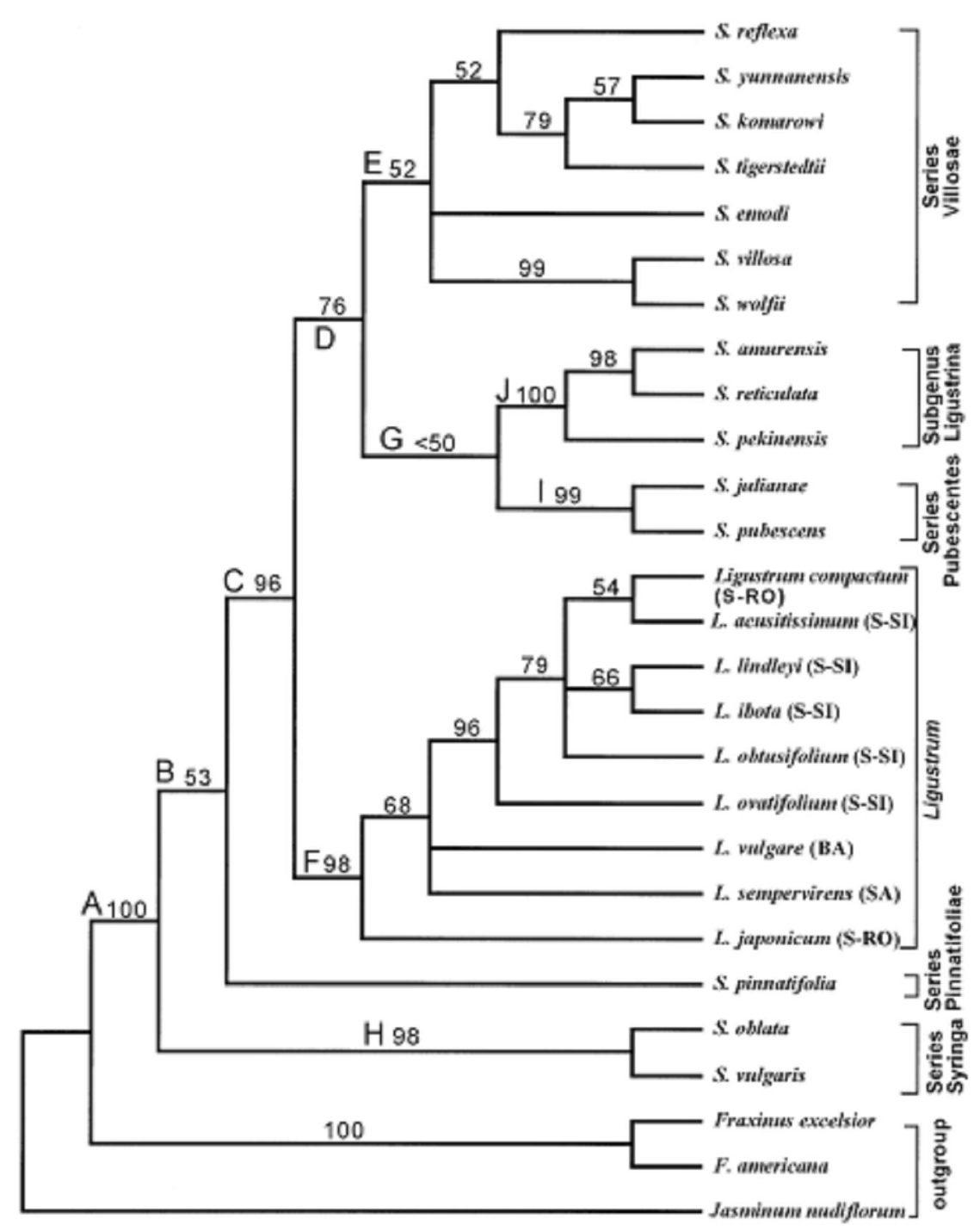

F1. ábra: A Syringa nemzetség Maximum likelihood konszenzus törzsfája ETS és ITS szekvenciák alapján. Az ábra bemutatja a Ligustrum fajok Syringa fajok közé ágyazottságát, és a Syringa fajok genuson belüli csoportjait. Az ábra Li et al. (2002) munkájából származik. 

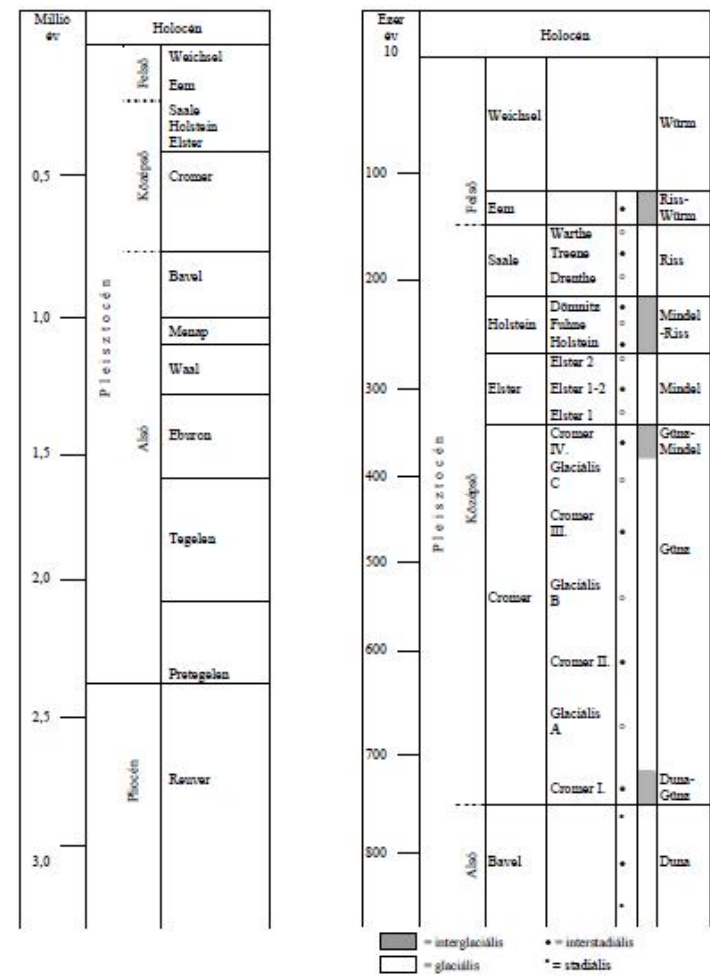

F2. ábra: a Pleisztocén korbeosztása az észak-európai és alpesi nevezéktan szerint. Az ábra JáraiKomlódi (2000) munkájából származik.

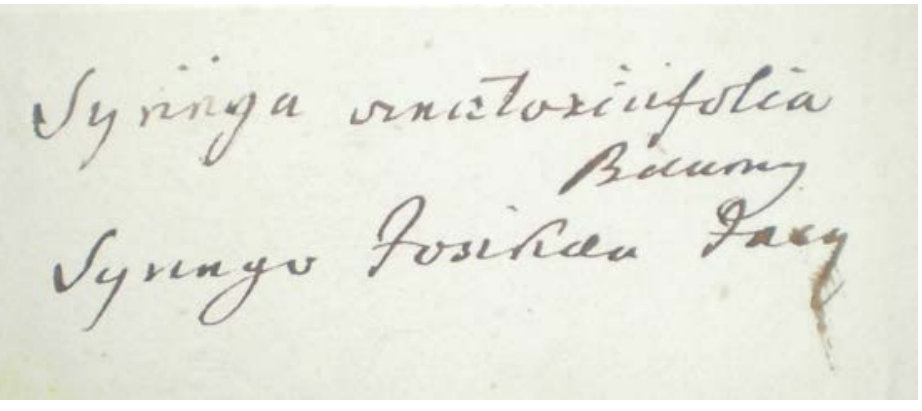

F3. ábra: Syringa josikaea herbáriumi lap etikettje, rajta a Syringa vincetoxicifolia Baumg. és Syringa josikaea Jacq. nevekkel. Minden bizonnyal Baumgartentől származik (Kolozsvár, BabesBolyai Tudományegyetem Botanikus Kert herbáriuma [CL], saját felvétel).

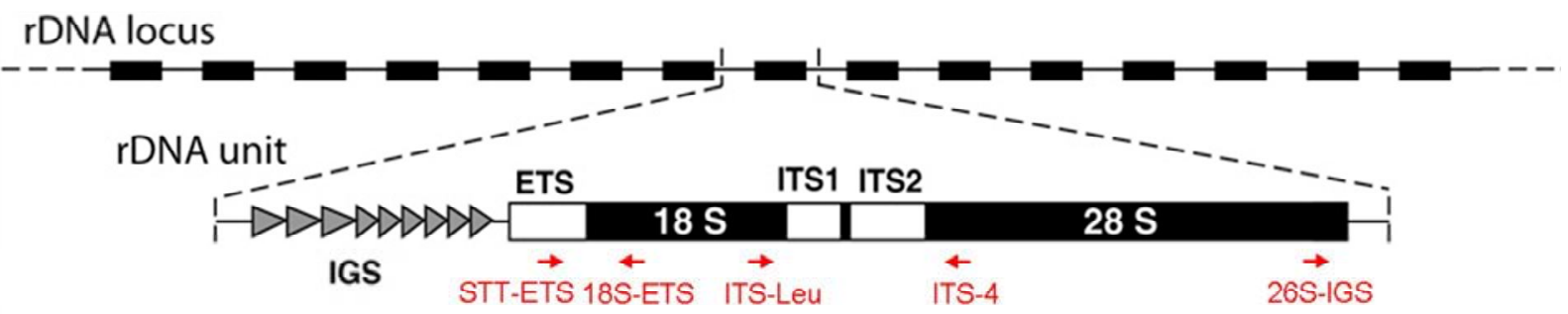

F4. ábra: A riboszomális gén felépítése, és egyes szakaszainak felszaporításához használt primerek tapadási helyének sematikus ábrája (Eickbush és Eickbush 2007, módosítva). 
F5. táblázat: A Syringa josikaea divergencia idejének analíziséhez használt fajok és DNS szekvenciáik.

\begin{tabular}{|c|c|c|c|}
\hline \multirow{2}{*}{ Fajnév } & \multicolumn{2}{|c|}{ GenBank azonosító } & \multirow{2}{*}{ Hivatkozás } \\
\hline & ETS & ITS & \\
\hline Fraxinus americana & HQ705331 & HQ705204 & Hinsinger 2010 \\
\hline Fraxinus angustifolia & HQ705332 & HQ705207 & Hinsinger 2010 \\
\hline Fraxinus ornus & HQ705489 & HQ705260 & Hinsinger 2010 \\
\hline Fraxinus xanthoxyloides & HQ705594 & HQ705315 & Hinsinger 2010 \\
\hline Jasminum nudiflorum & AF361280 & AF361301 & Li et al. 2002 \\
\hline Ligustrum acutissimum & AF361272 & AF361295 & Li et al. 2002 \\
\hline Ligustrum compactum & AF361269 & AF361292 & Li et al. 2002 \\
\hline Ligustrum ibota & AF361274 & AF361297 & Li et al. 2002 \\
\hline Ligustrum japonicum & AF361276 & AF361299 & Li et al. 2002 \\
\hline Ligustrum lindleyi & AF361270 & AF361293 & Li et al. 2002 \\
\hline Ligustrum obtusifolium & AF361271 & AF361294 & Li et al. 2002 \\
\hline Ligustrum ovalifolium & AF361273 & AF361296 & Li et al. 2002 \\
\hline Ligustrum vulgare & AF361275 & AF361298 & Li et al. 2002 \\
\hline Parasyringa sempervirens & AF297081 & AF361300 & Li et al. 2002 \\
\hline Syringa amurensis & AF297062 & AF297072 & Li et al. 2002 \\
\hline Syringa emodi & AF361256 & AF361256 & Li et al. 2002 \\
\hline Syringa julianae & AF361262 & AF277749 & Li et al. 2002 \\
\hline Syringa komarowi & AF361256 & AF361286 & Li et al. 2002 \\
\hline Syringa oblata & AF361265 & AF361288 & Li et al. 2002 \\
\hline Syringa pekinensis & AF297067 & AF297077 & Li et al. 2002 \\
\hline Syringa pinnatifolia & AF297071 & AF297081 & Li et al. 2002 \\
\hline Syringa pubescentes & AF297071 & AF277746 & Li et al. 2002 \\
\hline Syringa reflexa & AF361286 & AF361281 & Li et al. 2002 \\
\hline Syringa reticulata & AF297069 & AF297079 & Li et al. 2002 \\
\hline Syringa tigerstedtii & AF361281 & AF361287 & Li et al. 2002 \\
\hline Syringa villosa & AF361257 & AF361283 & Li et al. 2002 \\
\hline Syringa vulgaris & AF361266 & AF361289 & Li et al. 2002 \\
\hline Syringa wolfii & AF361258 & AF361284 & Li et al. 2002 \\
\hline Syringa yunnanensis & AF361259 & AF361285 & Li et al. 2002 \\
\hline
\end{tabular}




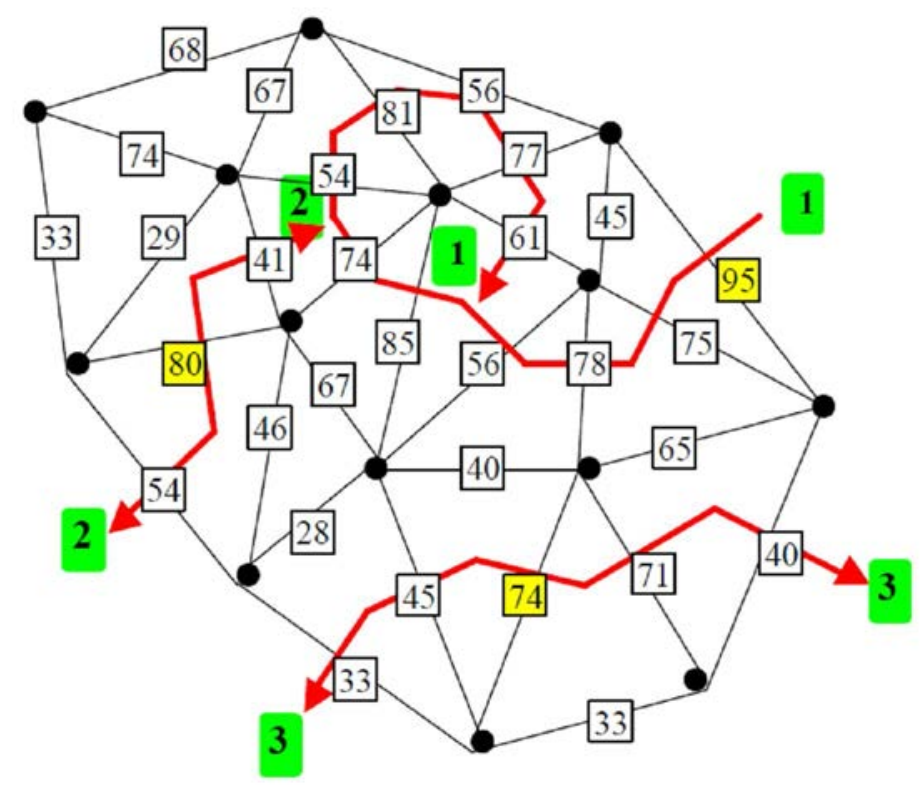

F6. ábra: A Barrier 2.2 (Manni et al. 2004) szoftver müködési elve egy példán bemutatva. A populációk (fekete pontokkal jelezve) a földrajzi koordinátáiknak megfelelően helyezkednek el, a köztük levő genetikai távolságokat a négyzetekben levő számok jelzik. A szoftver megkeresi a szomszédos populációk közötti legnagyobb genetikai távolság értéket (a példán 95), és a populációkat összekötő egyenesre merőleges Voronoï-poligon élét (pirossal) kijelölve megkezdi a választóvonal meghatározását. A választóvonal kijelölését abban az irányban folytatja, amelyik irányban a szomszédos populációk közötti genetikai távolság értékek közül a nagyobbikat találja (75 és 45 közül a 75, majd a 78 és 65 közül a 78 irányában). A választóvonal kijelölése addig tart, amíg a választóvonal saját magába nem ütközik. Ekkor kezdődik a második választóvonal kijelölése az első választóvonal alkotásában részt nem vevő legnagyobb szomszédos populációk közti genetikai távolság érték megkeresésével (80), és a választóvonal kijelölése az elsőhöz hasonló módon történik. A példában a választóvonal a második lépésre a térkép szélére ér, ekkor a választóvonal kezdő szakaszától ellentétes irányban indul a választóvonal folytatása, ami addig tart, amíg a második választóvonal bele nem ér az első választóvonalba. A harmadik választóvonal kijelölése az első kettőhöz hasonló módon történik. A példa ábrája a szoftver kézikönyvéböl származik. 
F7. táblázat: az Erdélyi-szigethegységben fellelt populációk

\begin{tabular}{|c|c|c|c|c|c|}
\hline Populáció név & rövidítés & patak/vízgyüjtő & Helyszín & $\begin{array}{l}\text { populáció } \\
\text { méret }\end{array}$ & élőhely \\
\hline Valea Iadului & $\mathrm{Jad}$ & Sebes-Körös & $\begin{array}{l}46,73^{\circ} \mathrm{N} \\
22,56^{\circ} \mathrm{E}\end{array}$ & $\begin{array}{l}\text { 50-100 } \\
\text { példány }\end{array}$ & $\begin{array}{l}\text { montán elegyes } \\
\text { lomberdő }\end{array}$ \\
\hline Stâna de Vale & Sta & Sebes-Körös & $\begin{array}{l}46,69^{\circ} \mathrm{N} \\
22,61^{\circ} \mathrm{E}\end{array}$ & $\begin{array}{l}\text { 50-100 } \\
\text { példány }\end{array}$ & $\begin{array}{l}\text { luc-elegyes égeres } \\
\text { erdő és rét mozaik, } \\
\text { ültetve is }\end{array}$ \\
\hline $\begin{array}{l}\text { Valea } \\
\text { Drăganului }\end{array}$ & Dra & Sebes-Körös & $\begin{array}{l}46,87^{\circ} \mathrm{N} \\
22,81^{\circ} \mathrm{E}\end{array}$ & egy példány & kert \\
\hline $\begin{array}{l}\text { Valea } \\
\text { Sebeşului }\end{array}$ & Seb & Sebes-Körös & $\begin{array}{l}46,84^{\circ} \mathrm{N} \\
22,86^{\circ} \mathrm{E}\end{array}$ & öt példány & $\begin{array}{l}\text { patakparti } \\
\text { magaskórós, } \\
\text { bükkerdő alja }\end{array}$ \\
\hline $\begin{array}{l}\text { Valea } \\
\text { Galbenei }\end{array}$ & Gal & Fehér-Körös & $\begin{array}{l}46,58^{\circ} \mathrm{N} \\
22,64^{\circ} \mathrm{E}\end{array}$ & két példány & montán bükkerdő \\
\hline $\begin{array}{l}\text { Valea } \\
\text { Arieșului }\end{array}$ & Ari & Nagy-Aranyos & $\begin{array}{l}46,46^{\circ} \mathrm{N} \\
22,85^{\circ} \mathrm{E}\end{array}$ & öt példány & lucfenyves szélén \\
\hline $\begin{array}{l}\text { Valea Crișul } \\
\text { Negru }\end{array}$ & Cne & Fekete-Körös & $\begin{array}{l}46,46^{\circ} \mathrm{N} \\
22,63^{\circ} \mathrm{E}\end{array}$ & $\begin{array}{l}\text { több tucat } \\
\text { példány }\end{array}$ & $\begin{array}{l}\text { montán jellegü } \\
\text { elegyes lomberdő }\end{array}$ \\
\hline $\begin{array}{l}\text { Valea } \\
\text { Someșul Cald }\end{array}$ & Som & Meleg-Szamos & $\begin{array}{l}46,70^{\circ} \mathrm{N} \\
23,09^{\circ} \mathrm{E}\end{array}$ & $\begin{array}{l}\text { 100-200 } \\
\text { példány }\end{array}$ & $\begin{array}{l}\text { zárt fenyőelegyes } \\
\text { bükkös }\end{array}$ \\
\hline
\end{tabular}

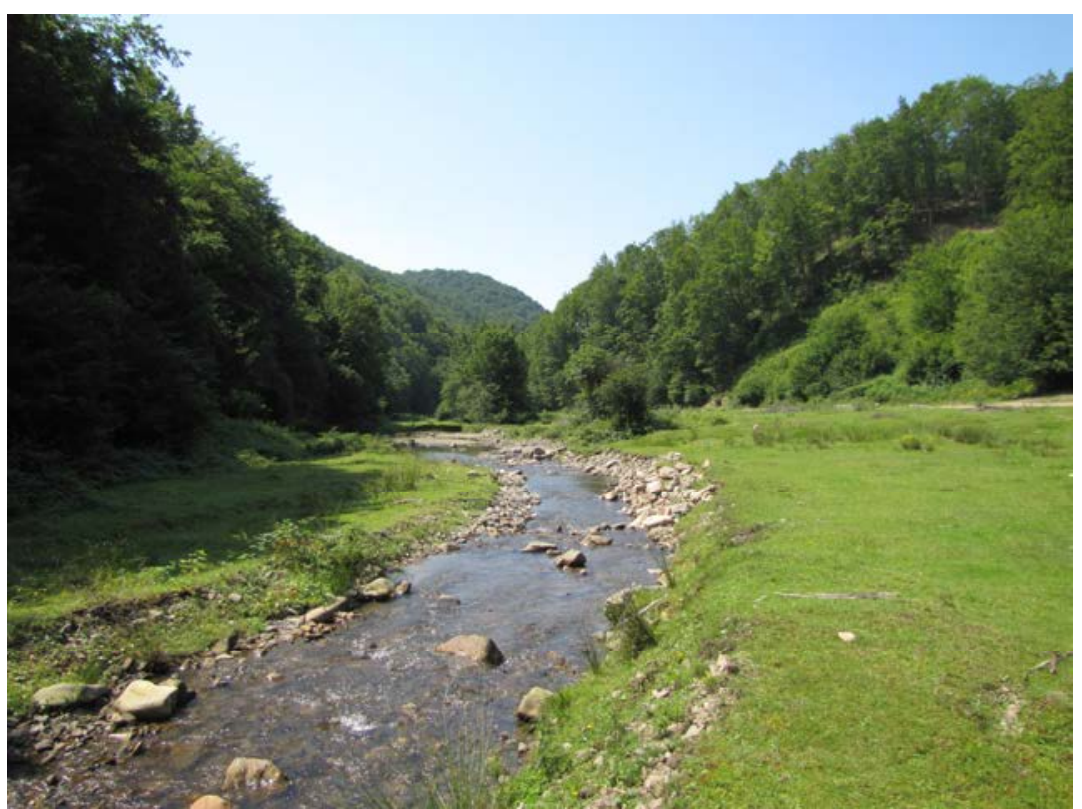

F8. ábra: Példa az Syringa josikaea Erdélyi-szigethegységi élőhelyeinek átalakítására és azok hatására: az Obersia-völgyi populáció egykori élőhelyén ma legelők, rétek vannak (saját felvétel). 


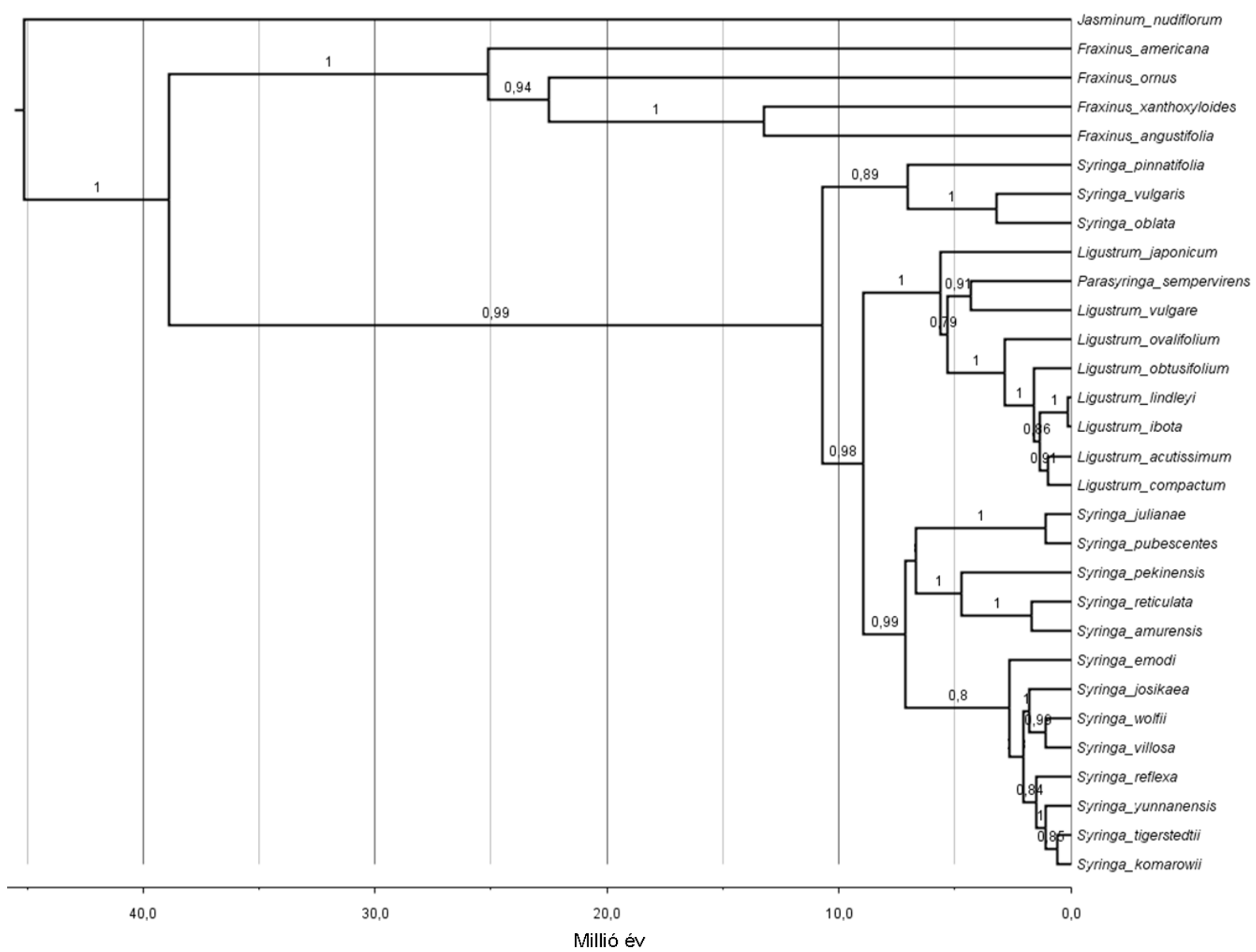

F9. ábra: Bayesi filogenetikai törzsfa és divergencia idők a riboszomális ETS és ITS szekvenciák alapján BEAST 1.7.5 szoftverrel. A törzsfa ágak felett a posteriori valószínüség értékek szerepelnek a 0,8-nál magasabb a posteriori valószínüséggel támogatott csoportoknál. Az X-tengely az evolúciós ágak szétválási idejét mutatja. 


\begin{tabular}{l}
\hline A \\
5' - GTATGTTGGATCCCTGCTAGGGCAGCGACAACATTCTCTTCATGCCTGTTCATTCGA \\
TGGTCGGATTTCGATGCGGTCATCTAGATTTCGGTTCCCTGTGTTGCATACCTGTTGCA \\
AAGGTACCTTGTTGGCTAAAACGACCCTATTTCGCCCTACGCTACGAGTTATATTGCAG \\
CTGAAGGTGAACCTAAAAGCATTCATCGTGTTCCACCYTGTTCACTTCAATTGTGGAG \\
GATTTGGACCTCGATGATGTGCTCGAATTCTCGGATGCGGAATACTAAGTGGGTACGA \\
GGACCTCGATCCTCTGTTTACCCTGAACAAGCGTTCTACGCTTCGTGCGAATGACGTTC \\
TTCCTTGTTCTGGACTTCTGTCCATGCAAGGTTGACGTCGAATAGGAATGCTACCTGGT \\
TGATCCTGCCAGTAGTCATATGCTTGTCTCAAAGATTAAGCCATGAT - 3' \\
B \\
5' - AGAGGAAGGAGAAGTCGTAACAAGGTTTCCGTAGGTGAACCTGCGGAAGGATCAT \\
TGTCGAAACCTGCAAAGCAGACCCGTGAACATGTTCTTACTCTTAGGGAGGACAACGT \\
GGGCACAKCTAACCAAGTTGTCCCACGTTGAAGCCCCATTCCGTCGATGTGCACAACC \\
GTGCCCGTCGTTCGGCTTAACGAACCCCGGCGCGGAAAGCGCCAAGGAAAACACAAA \\
ACACTGCTTGCCTCTCGTAGCCCCCGTTCGCGGTGTGCACCTGAGGATTGGGCGTGTGT \\
CGAATTTAAAACGACTCTCGGCAACGGATATCTCGGCTCTCGCATCGATGAAGAACGC \\
AGCAAAATGCGATACTTGGTGTGAATTGCAGAATCCCGTGAACCATCGAGTTTTGAA \\
CGCAAGTTGCGCCCGAAGCCATTATGCTGAGGGCACGTCTGCCTGGGCGTCACGCATA \\
GCGTCGCCCTCCACCTTCGTCCCTAAACGGGTTGTAGGTGTTTGGGTTGGATATTGGCC \\
TCCCGTGCGTCTCGGTGTGCGGTTGGCCTAAATGTGATTCGGCATCGACGTATGTCTCG \\
ACAATTGGTGGTTGAAGACCTCAACTCTCGTTTGTCGTGCTAGATTGCGTTGTTGGC \\
TCGAATGCGTTGACCCCGATGGTGCTTTGCAMICTCGACAGAGACCCCAGGTCAGGCGG \\
GATTACCCGCTGAGTTTAAGCATATCAAT - 3' \\
Jelmagyarázat: a riboszomális RNS-t kódoló lókuszok különbözö szakaszait jelző színezés \\
ETS - 18 s rRNS - ITS-1 - 5,8 S rRNS - ITS-2 - 26 S rRNS
\end{tabular}

F10. ábra: A Syringa josikaea populációi között variábilis bázis pozicíók a riboszomális (A) ETS és (B) ITS szakaszokban. A variábilis pozíciók piros háttérrel vannak kiemleve. A riboszomális RNS-t kódoló lókuszok szakaszahatárainak meghatározása a ETS esetében az Olea europaea AJ865373 GenBank azonosítójú szekvenciájával (Maggini et al. 2008), az ITS esetében pedig a Syringa wolfii AF361284 GenBank azonosítójú szekvenciájával (Li et al. 2002) való illesztés alapján történt MEGA5 (Tamura et al. 2011) szoftverben. 
F11. táblázat: A Syringa josikaea populációi közti genetikai távolságok mátrixa a STRUCTURE 2.3.4 (Hubisz et al. 2009) analízis eredményei alapján $\mathrm{K}=5$ csoportnál a populációk átlagai alapján, euklideszi távolságokat használva.

\begin{tabular}{|c|c|c|c|c|c|c|c|c|c|c|c|c|c|c|c|c|c|c|c|c|c|c|c|c|}
\hline & $\mathrm{Jad}$ & Sta & Dra & Seb & Gal & Ari & Cne & Som & Sva & Pid & Pro & Hra & Yal & Zde & Zbi & Zpa & Pas & Tys & Lat & Kli & $\mathrm{Jab}$ & Zan & Lut & Roz \\
\hline \multicolumn{25}{|l|}{$\mathrm{Jad}$} \\
\hline Sta & 0,203 & & & & & & & & & & & & & & & & & & & & & & & \\
\hline Dra & 0,190 & 0,015 & & & & & & & & & & & & & & & & & & & & & & \\
\hline Seb & 0,196 & 0,008 & 0,011 & & & & & & & & & & & & & & & & & & & & & \\
\hline Gal & 0,153 & 0,089 & 0,085 & 0,083 & & & & & & & & & & & & & & & & & & & & \\
\hline Ari & 0,570 & 0,769 & 0,756 & 0,763 & 0,713 & & & & & & & & & & & & & & & & & & & \\
\hline Cne & 0,293 & 0,490 & 0,479 & 0,483 & 0,423 & 0,344 & & & & & & & & & & & & & & & & & & \\
\hline Som & 1,117 & 1,314 & 1,301 & 1,308 & 1,260 & 0,550 & 0,881 & & & & & & & & & & & & & & & & & \\
\hline Sva & 0,984 & 1,129 & 1,121 & 1,121 & 1,056 & 0,851 & 0,752 & 1,077 & & & & & & & & & & & & & & & & \\
\hline Pid & 1,050 & 1,189 & 1,182 & 1,181 & 1,126 & 0,944 & 0,830 & 1,176 & 0,310 & & & & & & & & & & & & & & & \\
\hline Pro & 1,175 & 1,307 & 1,302 & 1,301 & 1,253 & 1,071 & 0,968 & 1,280 & 0,526 & 0,219 & & & & & & & & & & & & & & \\
\hline Hra & 0,958 & 1,098 & 1,091 & 1,090 & 1,031 & 0,861 & 0,735 & 1,122 & 0,214 & 0,126 & 0,339 & & & & & & & & & & & & & \\
\hline Yal & 1,116 & 1,235 & 1,227 & 1,227 & 1,157 & 1,010 & 0,935 & 1,197 & 0,533 & 0,840 & 1,055 & 0,737 & & & & & & & & & & & & \\
\hline Zde & 1,044 & 1,170 & 1,163 & 1,163 & 1,085 & 0,913 & 0,853 & 1,110 & 0,581 & 0,868 & 1,082 & 0,757 & 0,272 & & & & & & & & & & & \\
\hline Zbi & 1,026 & 1,161 & 1,153 & 1,152 & 1,084 & 0,909 & 0,812 & 1,125 & 0,218 & 0,521 & 0,735 & 0,424 & 0,320 & 0,419 & & & & & & & & & & \\
\hline Zpa & 1,092 & 1,232 & 1,226 & 1,226 & 1,175 & 0,972 & 0,874 & 1,188 & 0,437 & 0,136 & 0,107 & 0,248 & 0,970 & 0,990 & 0,652 & & & & & & & & & \\
\hline Pas & 1,038 & 1,170 & 1,162 & 1,161 & 1,092 & 0,922 & 0,830 & 1,133 & 0,289 & 0,595 & 0,809 & 0,495 & 0,246 & 0,367 & 0,073 & 0,725 & & & & & & & & \\
\hline Tys & 0,450 & 0,573 & 0,567 & 0,567 & 0,521 & 0,628 & 0,339 & 1,110 & 0,639 & 0,625 & 0,734 & 0,551 & 0,954 & 0,920 & 0,751 & 0,660 & 0,790 & & & & & & & \\
\hline Lat & 1,030 & 1,152 & 1,145 & 1,144 & 1,073 & 0,927 & 0,847 & 1,139 & 0,495 & 0,802 & 1,019 & 0,692 & 0,090 & 0,229 & 0,293 & 0,930 & 0,223 & 0,876 & & & & & & \\
\hline Kli & 1,199 & 1,308 & 1,300 & 1,300 & 1,231 & 1,099 & 1,037 & 1,267 & 0,706 & 1,013 & 1,228 & 0,909 & 0,173 & 0,318 & 0,493 & 1,143 & 0,419 & 1,088 & 0,226 & & & & & \\
\hline $\mathrm{Jab}$ & 1,104 & 1,222 & 1,220 & 1,217 & 1,139 & 0,977 & 0,931 & 1,189 & 0,936 & 1,038 & 1,176 & 0,960 & 0,994 & 0,743 & 0,942 & 1,101 & 0,946 & 1,006 & 0,935 & 1,056 & & & & \\
\hline Zan & 1,011 & 1,140 & 1,133 & 1,132 & 1,057 & 0,891 & 0,809 & 1,106 & 0,427 & 0,724 & 0,940 & 0,614 & 0,201 & 0,168 & 0,252 & 0,850 & 0,201 & 0,827 & 0,144 & 0,334 & 0,808 & & & \\
\hline Lut & 1,053 & 1,174 & 1,172 & 1,169 & 1,094 & 0,938 & 0,880 & 1,175 & 0,910 & 0,967 & 1,085 & 0,899 & 1,049 & 0,816 & 0,951 & 1,015 & 0,966 & 0,927 & 0,986 & 1,132 & 0,158 & 0,854 & & \\
\hline Roz & 0,447 & 0,581 & 0,576 & 0,575 & 0,512 & 0,587 & 0,299 & 1,070 & 0,622 & 0,643 & 0,772 & 0,554 & 0,901 & 0,823 & 0,717 & 0,690 & 0,751 & 0,168 & 0,818 & 1,028 & 0,843 & 0,752 & 0,767 & \\
\hline Kel & 1,052 & 1,177 & 1,173 & 1,171 & 1,089 & 0,921 & 0,866 & 1,137 & 0,790 & 0,947 & 1,114 & 0,855 & 0,780 & 0,525 & 0,760 & 1,031 & 0,754 & 0,941 & 0,725 & 0,837 & 0,219 & 0,601 & 0,324 & 0,786 \\
\hline
\end{tabular}

A Barrier 2.2 (Manni et al. 2004) által meghatározott választóvonalak kezdőpontjai: A:Som-Seb; B Sva-Dra vagy Sva-Seb (ekvivalensek); C: Kli-Tys; D: Jab-Kli; E: Lut-Pas, A választóvonalakat lásd a 15. ábrán, a szoftver müködésének leírását az Anyagok és módszerek fejezet tartalmazza. 